\title{
Improving the Regulation of Safety at DOE Nuclear
} Facilities

\section{Appendices}

FINAL REPORT OF THE

ADVISORY COMMITTEE ON EXTERNAL REGULATION OF DEPARTMENT OF ENERGY NUCLEAR SAFETY

DECEMBER 1995

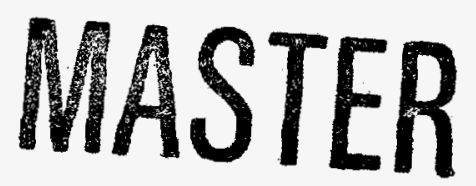

63 Printed with soy ink on recycled paper 
Additional copies of the Final Report of the Advisory Committee on External Regulation of Department of Energy Nuclear Safety and selected related reports can be obtained from the U.S. Department of Energy's Environment, Safety and Health (ES\&H) Information Center at:

Environment, Safety and Health Information Center

EH-72

CXXI-20030

U.S. Department of Energy

19901 Germantown Road

Germantown, MD 20874-1290

$1-800-473-4375$

Copies also are available:

- to DOE and DOE contractors from the Office of Scientific and Technical Information, P.O. Box 62, Oak Ridge, TN 37831; prices and information are available at (615) 576-8401.

- to the public from the National Technical Information Service, U.S. Department of Commerce, 5285 Port Royal Road, Springfield, VA 22161; prices and information are available at (703) 487-4650.

An Internet World Wide Web site is available which contains various Advisory Committee information including: charter, Interim Status Report, subcommittee reports (working drafts), staff papers (working drafts), and information related to each committee meeting (agenda, press release, Federal Register Notice, minutes, and transcript). The address is maintained by the DOE Office of Environmental Management, and is located at:

http://www.em.doe.gov/acd/index.html. 


\section{CONTENTS}

APPENDIX A: INVITED AND PUBLIC SPEAKER SESSIONS $\ldots \ldots \ldots \ldots \ldots \ldots \ldots$ A1

APPENDIX B: ADVISORY COMMITTEE CHARTER AND MEMBER BIOGRAPHIES B1

APPENDIX C: DOE NUCLEAR FACILITIES AND SITES $\ldots \ldots \ldots \ldots \ldots \ldots \ldots \ldots$ C1

APPENDIX D: CURRENT REGULATORY AUTHORITY FOR DOE NUCLEAR

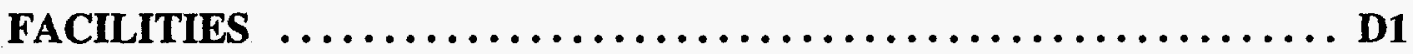

APPENDIX E: NATIONAL SECURITY AND EXTERNAL REGULATION OF NUCLEAR

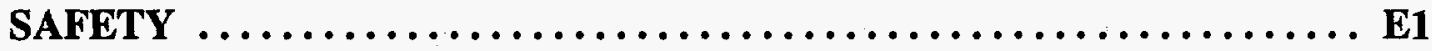




\title{
Appendix A
}

\author{
Invited and Public \\ Speaker Sessions
}




\section{Role of the Public}

\section{Introduction}

The Advisory Committee on External Regulation of DOE Nuclear Safety used a variety of approaches to inform the public and workers about the Committee's activities and solicit their input. Public input from a variety of viewpoints and sources provided the Committee with information to use in the development of their recommendations.

\section{Role of the Public}

\section{A. Personal Interaction and Stakeholder Involvement}

1. Pre-Visits with Stakeholders

Committee staff conducted pre-meeting visits with stakeholders at or near the DOE sites. Meetings were held with Federal, Tribal, State, and local government representatives, as well as local and national stakeholder organizations. These groups were informed of the Committee's activities and mission and encouraged to participate.

During these pre-visits, Committee staff briefed DOE, contractor management, and workers about the Committee's mission and activities. In an effort to inform workers about Committee meetings and encourage worker participation, flyers announcing the meeting were posted and electronic mail messages were sent to employees at the respective DOE sites. Articles about the Committee and meeting notices were printed in site news bulletins.

2. Panel Session Presentations by Stakeholders at Advisory Committee Meetings

Stakeholders were consulted in developing meeting agendas and participated in panel session presentations during Committee meetings.

3. Public Meetings/Stakeholder Comments

The Committee held eight meetings in nine months, all of which were open to the public. 60 members of stakeholder organizations addressed their concerns about DOE safety. Over 350 members of the public attended the meetings.

Public comment sessions were held in conjunction with all the Committee meetings. Forty-seven concerned citizens shared their viewpoints and answered Committee questions. 


\section{Written Comments}

For concerned citizens unable to attend the public comment sessions, four different options for the Committee to receive comments and input were offered: U.S. Mail, Facsimile, Electronic Bulletin Board, and Electronic Mail.

\section{B. Dissemination of Advisory Committee Information}

1. Advisory Committee Support Staff

Public information materials such as press releases, Federal Register Notices, and factsheets were developed and distributed to keep the public informed of Committee meetings and activities. Meeting minutes, transcripts and the Committee's Status Report were also available to the public. This information was distributed upon request, at Committee meetings, and sent to DOE Reading Rooms around the country. The Committee maintained a mailing list of 495 persons. Over 8,600 pieces of information were distributed during the Committee's tenure.

2. Information Center - Toll-free phone line

An information repository with a toll-free number was established to respond to information requests and answer Committee-related questions. Over 500 calls were received on the toll-free number.

3. Internet/World Wide Web

Committee information was also maintained on a World Wide Web Page on the Internet, where it could be viewed and/or downloaded. Over 17,500 people signed on to the Committee's page.

\section{Summary}

At Committee meetings, Committee members actively engaged in discussions with concerned citizens, workers, and management concerning safety and health issues at DOE nuclear facilities. Public comments were considered int the development of the Committee's report. 
Advisory Committee on External Regulation of U.S. Department of Energy Nuclear Safety - Committee Meeting Locations \& Dates -

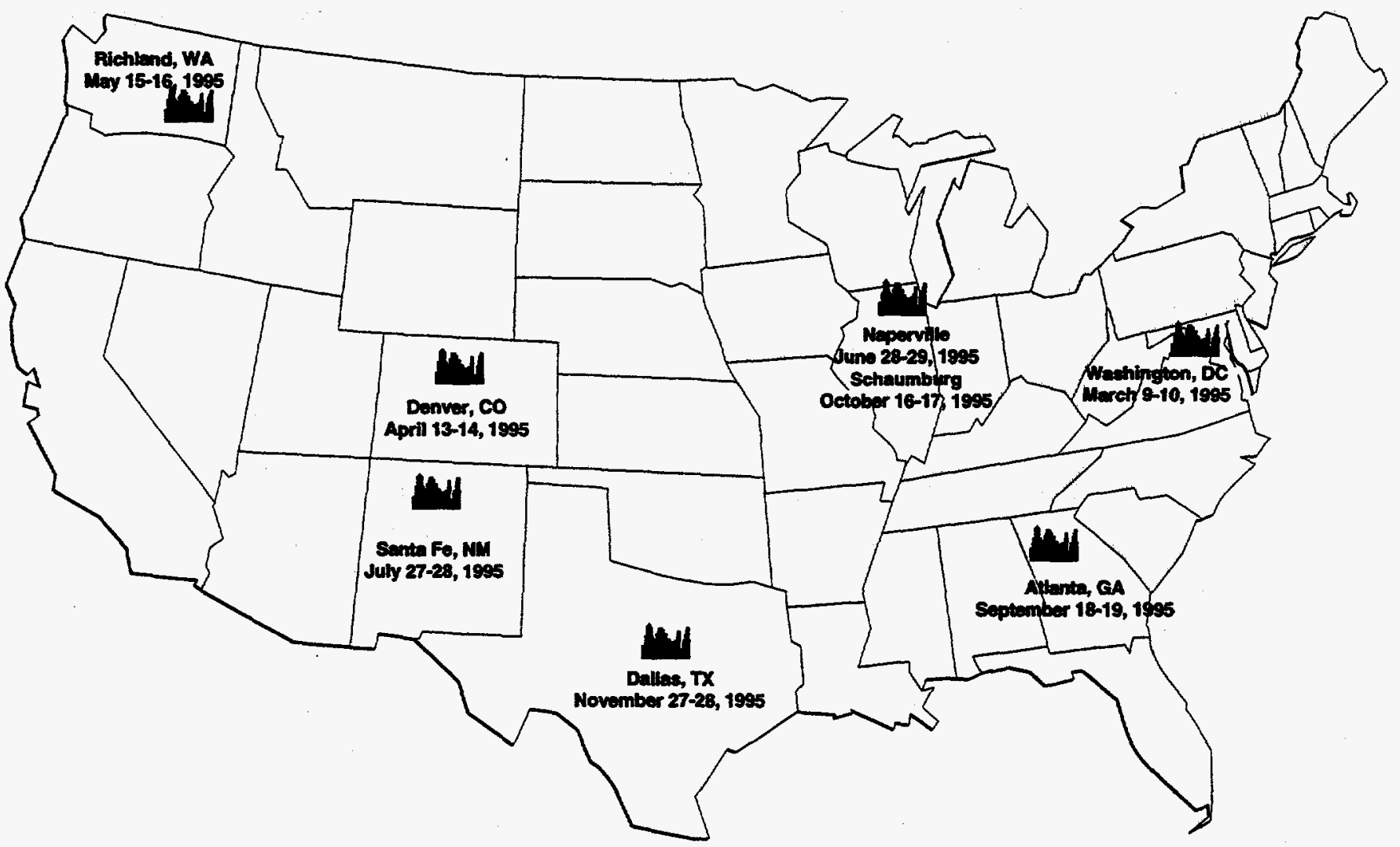


SPEAKERS AT THE MEETINGS OF

THE ADVISORY COMMITTEE ON EXTERNAL REGULATION OF DOE NUCLEAR SAFETY

WASHINGTON, DC

March 9-10, 1995

INVITED

Hazel R. O'Leary

Secretary of Energy

Dr. John Ahearne

Advisory Committee on External Regulation of

DOE Nuclear Safety

Robert Alvarez

Deputy Assistant Secretary for National

Security and Environmental Restoration, U.S.

DOE

Susan Beard

Deputy Assistant General Counsel for Standards of Conduct, U.S. DOE

John T. Conway

Chair, Defense Nuclear Facilities Safety Board

Thomas H. Isaacs

Executive Director, Advisory Committee on

External Regulation of DOE Nuclear Safety

Nisha Kumar

Office of the General Counsel, U.S. DOE

Donald Pearman, Jr.

Associate Deputy Secretary for Field

Management, U.S. DOE

Mary Anne Sullivan

Deputy General Counsel for Health, Safety and

Environment, U.S. DOE

JoAnne Whitman

Deputy Advisory Committee Management

Officer, U.S. DOE

\section{PUBLIC}

Steven Buckley

Robert Keller

Richard Miller 


\section{ROCKY FLATS, COLORADO}

April 13-14, 1995

\section{INVITED}

Anson Burlingame

President, EG\&G Rocky Flats Environmental

Technology Site

John Davis

Vice President, EG\&G Rocky Flats

Environmental Technology Site

Bill Glover

Director of Performance Assurance, EG\&G

Rocky Flats Environmental Technology Site

Paul Hartman

Office of Environment Safety and Health, Site

Resident at Rocky Flats Field Office, U.S. DOE

Mark Holt

Congressional Research Service

Roy Kasdorf

Program Manager, Defense Nuclear Facilities

Safety Board

Jack McGraw

Deputy Regional Administrator, U.S.

Environmental Protectional Agency, Region VII

Robert Quillin

Director, Radiation Control Division, Colorado

Department of Public Health and Environment

Mark Silverman

Manager, Rocky Flats Field Office, U.S. DOE

\section{PUBLIC}

Bill Carreon

RFIPCAC

Jim Center

United Steelworkers of America

Sam Cole

Physicians for Social Responsibility

Sam Dixon

City of Westminister

Paula Elofson-Gardine

Environmental Information Network

Joe Goldfield

Citizen's Advisory Board

Ray Guyer

U.S. DOE

Jerry Hardin

United Steelworkers of America

Scott Hatfield

Susan Hurst

Environmental Information Network

John Impey

Colorado Peace Action

Sharon Klusman

Citizen

Kim Kocol

Rocky Flats Employee

Greg Marsh

Rocky Flats Cleanup Commission 


\section{ROCKY FLATS, COLORADO}

April 13-14, 1995

\section{PUBLIC (cont.)}

Tom Marshall

Rocky Mountain Peace Center

David Navarro

Citizen's Advisory Board

Steve Smith

Jim Stone

Rocky Flats Cleanup Commission

Kathleen Taylor

EG\&G

Ted Tegeler

United Steel Worker of America

Kenneth Werth (submitted written statement) 


\section{RICHLAND, WASHINGTON \\ May 15-16, 1995}

INVITED

Walter Apley

Associate Director or Operations, Pacific

Northwest Laboratory (Battelle)

Steven Blush

Consultant

Don Bushy

Hanford Atomic Metal Trade Council

Allen Conklin

Head, Air Emissions and Defense Waste

Section, Washington Department of Health

Rich Gerglund

Building Trades Council

Russell Jim

Manager, Environmental Restoration and Waste

Management Program, Yakama Indian Nation

Jay Manning

Senior Assistant Attorney General, Washington

Attorney General's Office

Todd Martin

Hanford Education Action League

Joe Nemec

President, Bechtel Hanford, Inc.

Ivan Selin

Chairman, U.S. Nuclear Regulatory

Commission

Douglas Sherwood

Hanford Project Office, U.S. Environmental

Protection Agency, Region X
Dan Silver

Assistant Director for Waste Management

Program, Washington Department of Ecology

LeMar Trego

President Westinghouse Hanford Company

John Wagoner

Manager, Richland Operations Office, U.S.

DOE

Jim Watts

Oil, Chemical and Atomic Workers

J.R. Wilkinson

Manager, Special Sciences and Research

Program, Confederated Tribes of the Umatilla

Indian Reservation

\section{PUBLIC}

Walter Blair

Ron Gouge

Oil, Chemical and Atomic Workers

James Hansen

Mayor, City of Richland

H. Gaidine Oglesbee

Paul Stansbury

David Stewart/Smith

Administrator, Facility Regulation Division

Oregon Department of Energy

Daniel Strom

Tim Van Reenen

Oil, Chemical and Atomic Workers 


\section{NAPERVILLE, ILLINOIS}

June 28-29, 1995

\section{INVITED}

Dr. M. Sue Davis

Associate Director, Reactor Safety and Security, Brookhaven National Laboratory

John DeLooper

Associate Director, Environmental Safety and

Health, Princeton Plasma Physics Laboratory

Joseph DiNunno

Defense Nuclear Facilities Safety Board

Thomas P. Grumbly

Assistant Secretary for Environmental

Management, U.S. DOE

Dr. Martha Krebs

Director, Office of Energy Research, U.S. DOE

Cherri Langenfeld

Manager, Chicago Operations Office, U.S. DOE

Dr. Tara O'Toole

Assistant Secretary for Environment, Safety and

Health, U.S. DOE

John Peoples, Jr.

Director, Fermi National Accelerator Laboratory

Dr. Alan Schriesheim

Director, Argonne National Laboratory

Dr. Charles Shank

Director, Lawrence Berkeley Laboratory

Dr. Jerry Swanks

Associate Director, Operations, Environmental

Safety and Health, Oak Ridge

Dr. Alvin Trivelpiece

Director, Oak Ridge National Laboratory

\section{PUBLIC}

Patricia Nied

President, Kingery East Community Association 


\section{SANTA FE, NEW MEXICO \\ July 27-28, 1995}

\section{INVITED}

Adam Babich

Editor-in-Chief, Environmental Law Reporter

Dr. Everet H. Beckner

Principal Deputy Assistant Secretary for

Defense

Programs, U.S. DOE

Beatrice Brailsford

Snake River Alliance

Lisa Crawford

FRESH, Incorporated

Joseph A. Dear

Assistant Secretary for Occupational Safety and Health, U.S. Department of Labor

Nicholas S. Dienes

Assistant Manager, Office of Technical

Management and Operations, Albuquerque

Office, U.S. DOE

Stephen J. Guidice

Assistant Manager for Energy, Science and

Technology, Albuquerque Operations Office,

U.S. DOE

Dr. James Jackson

Deputy Director, Los Alamos National

Laboratory

Dr. Robert W. Kuckuck

Deputy Director for Operations, Lawrence

Livermore National Laboratory

Milton Lockhard

Responsible Environmental Action League

Greg Mello

Los Alamos Study Group
Dr. Thomas E. Murley

Former Director, U.S. Nuclear Regulatory

Commission

C. Paul Robinson

Vice President of Laboratory Development, Sandia National Laboratories

\section{PUBLIC}

Christine Chandler

Responsible Environmental Action League

George Chandler

Responsible Environmental Action League

Don Hancock

Southwest Research and Information Center

Chris Maculas

Douglas Mieklejohn

New Mexico Law Center and the Pueblo San

Ildefonson

Peggy Prince

Los Alamos Study Group

Kathleen Sabo

Concerned Citizens for Nuclear Safety

Al Shapolia

Elliott Skinner

Los Alamos Study Group

John Stroud

Los Alamos Study Group

John Ussery

New Mexico Green Party and Los Alamos

National Laboratory 2000 


\section{ATLANTA, GEORGIA}

September 18, 1995

INVITED

None

\section{SCHAUMBURG, ILLINOIS}

October 16, 1995

INVITED

None

DALLAS, TEXAS

November 27-28, 1995

INVITED

None

PUBLIC

None

\section{PUBLIC}

Richard Allen

Manager, Office of Environmental Safety, Illinois Department of Nuclear Safety 


\section{Appendix B}

\section{Advisory Committee Charter and Member Biographies}





\section{DEPARTMENT OF ENERGY \\ CHARTER \\ ADVISORY COMMITTEE ON EXTERNAL REGULATION \\ OF DEPARTMENT OF ENERGY NUCLEAR SAFETY}

\section{COMMITTEE'S OFFICIAL DESIGNATION:}

Advisory Committee on External Regulation of Department of Energy Nuclear Safety (the "Advisory Committee" or "Committee").

\section{OBJECTIVES AND SCOPE OF ACTIVITIES:}

To provide advice, information and recommendations to the Secretary of Energy, the White House Office of Environmental Policy and the Office of Management and Budget, on whether and how new and existing Department of Energy facilities and operations, except those facilities and operations covered under Executive Order 12344 (U.S.C. 7158), might be externally regulated to ensure nuclear safety. The Committee shall conduct an assessment of the technical, regulatory, institutional and resource issues related to the potential establishment of an external regulatory regime for nuclear safety with respect to Department of Energy facilities and operations.

The assessment will begin with (a) an identification of the Department of Energy's nuclear facilities and operations now and projected in the future, and (b) an appraisal of the current nuclear safety oversight structure (no change from current law) in order to have a baseline against which to identify and measure meaningful improvements to nuclear safety, and to understand the implications, cost and otherwise, that would derive from options of change.

The assessment will include an evaluation of the historical separation between commercial and defense nuclear activities; the potential advantages and disadvantages of external safety regulation compared to the existing regulatory framework for environment, safety and health; and the concerns and criticisms that have been expressed about DOE's safety oversight by the Congress, the National Academy of Sciences, the Advisory Committee on Nuclear Facility Safety, the Defense Nuclear Facilities Safety Board, and others. Significant transition issues associated with any new regulatory regime will be identified, including a realistic appraisal of both Federal and non-Federal resource impacts.

The Committee's deliberations may result in a set of regulatory options, rather than a single recommendation, for establishing external regulation of nuclear safety at Department of Energy facilities and operations. In this event, the Committee report shall include a discussion of the advantages and disadvantages for each proposed regulatory option. 


\section{DESCRIPTION OF COMMITTEE'S DUTIES:}

The duties of the Advisory Committee are solely advisory. They shall be:

a. Conduct the assessment, as set forth in Section 2 of this Charter, and develop a report and recommendations on whether and how the Department of Energy might be externally regulated to ensure nuclear safety.

b. Ensure that full consideration is given to the ongoing and planned Departmental efforts to ensure nuclear safety. The Committee shall conduct its activities so as not to detract from the Department's critical efforts to improve current safety conditions.

c. Ensure meaningful and broad stakeholder participation in the assessment, and in the development of recommendations.

\section{OFFICIALS TO WHOM THIS COMMITEE REPORTS:}

The Advisory Committee shall report to the Secretary of Energy. The Committee's report and recommendations shall be submitted simultaneously to the Secretary of Energy, the White House Office of Environmental Policy and the Office of Management and Budget.

\section{DURATION AND TERMINATION DATE:}

The Advisory Committee shall terminate thirty (30) days after submission of its report and recommendations to the Secretary of Energy, the White House Office of Environmental Policy and the Office of Management and Budget. The Committee will establish a due date during its initial deliberations. This Charter shall expire two (2) years from the date of its establishment, subject to renewal and extension by the Secretary of Energy.

\section{AGENCY RESPONSIBLE FOR PROVIDING NECESSARY SUPPORT:}

Direct financial and administrative support for the Committee shall be provided by the Department of Energy. Upon request, each participating Federal agency shall support the Committee by providing pertinent information relative to that agency. Some participating entities will also be asked to provide staff support to the Committee.

\section{ESTIMATED ANNUAL OPERATING COST:}

The estimated annual operating cost of direct support to the Committee is $\$ 1.0$ million, and requires approximately eight (8) person-years of full-time staff support. 


\section{ESTIMATED NUMBER AND FREQUENCY OF MEETINGS:}

The Committee is expected to meet approximately eight (8) times, to be scheduled as the Committee deems necessary to complete its duties.

\section{SUBCOMMITTEES:}

To facilitate the functioning of the Committee, subcommittees may be formed. The objective of the subcommittees would be to undertake fact-finding and analysis for the parent committee, with respect to matters which are related to the responsibilities of the parent committee.

The Chairperson, in consultation with the Under Secretary of Energy, will appoint members of subcommittees. Members from outside the Committee may be appointed to any subcommittee to secure the expertise necessary to conduct subcommittee business. Subcommittees shall meet as the Advisory Committee deems appropriate.

\section{MEMBERS:}

Approximately twenty (20) Advisory Committee members shall be appointed by the Secretary of Energy for a term of two years, which may be extended by the Secretary. Membership shall include representatives of the affected Federal entities, appropriate experts, and key non-Federal stakeholders. Membership shall reflect a balance of expertise and viewpoints. Non-Federal Committee members may be compensated in accordance with Federal law.

\section{CHAIRPERSON:}

The Secretary of Energy shall designate a Chairperson from among the members of the Advisory Committee.

This Charter for the Advisory Committee named above is hereby approved on:

Date: January 25,1995

Original Signed by "JoAnn Whitman" for

Marcia L. Morris

Advisory Committee Management Officer

Date Filed:_January 25, 1995 


\section{Advisory Committee on External Regulation of Department of Energy Nuclear Safety}

\author{
Dr. John F. Ahearne (Co-Chair) \\ Lecturer in Public Policy, Duke University and \\ Executive Director, Sigma Xi, The Scientific \\ Research Society \\ Research Triangle Park, North Carolina
}

\author{
Andrew P. Caputo \\ Senior Attorney \\ Natural Resources Defense Council \\ Washington, D.C.
}

\section{Joseph A. Dear}

Assistant Secretary for Occupational Safety and Health

U.S. Department of Labor

Washington, D.C.

\section{Joseph J. DiNunno}

Member

Defense Nuclear Facilities Safety Board

Washington, D.C.

\section{Victor A. Franklin}

Chief Environmental Counsel

Westinghouse Electric Corporation

Pittsburgh, Pennsylvania

\section{Dr. Jerry M. Freedman}

Deputy Assistant to the Secretary of

Defense (Nuclear Matters)

U.S. Department of Defense

Washington, D.C.

\author{
Beverly E. C. Gattis \\ President \\ Serious Texans Against Nuclear Dumping \\ Amarillo, Texas
}

\author{
Gerard F. Scannell (Co-Chair) \\ President \\ National Safety Council \\ Itasca, Illinois
}

\section{T. J. Glauthier \\ Associate Director for Natural Resources, \\ Energy and Science \\ Office of Management and Budget \\ Washington, D.C.}

Mark A. Griffon

Health Physicist

Oil, Chemical, and Atomic Workers

International Union

Salem, New Hampshire

\section{Dr. Andrew C. Kadak \\ President and Chief Executive Officer \\ Yankee Atomic Electric Company \\ Bolton, Massachusetts}

\section{Dr. C. Judson King}

Interim Provost and Senior Vice President

University of California System

Oakland, California

Matthew Leivas, Sr.

Chairman and Chief Executive Officer

Chemehuevi Tribe

Havasu Lake, California

Dr. Walter E. Massey ${ }^{1}$

Provost and Senior Vice President - Academic

Affairs

University of California

Oakland, California

${ }^{1}$ Resigned on June 8, 1995; replaced by Dr. C. Judson King. 


\section{Advisory Committee on External Regulation of Department of Energy Nuclear Safety (cont.)}

\author{
Dr. Mildred McClain \\ Executive Director \\ Citizens for Environmental Justice \\ Savannah, Georgia
}

\section{Dr. James Melius}

Scientific and Medical Director

Center to Protect Workers' Rights

AFL-CIO

Washington, D.C.

\section{Michael H. Mobley}

Director, Department of Environment and

Conservation

Division of Radiological Health

State of Tennessee

Nashville, Tennessee

\section{Dr. Thomas E. Murley}

Consultant

Former Director, Nuclear Reactor Regulation

U.S. Nuclear Regulatory Commission

Potomac, Maryland

\section{Robert H. Neill}

\section{Director}

New Mexico Environmental Evaluation Group

Albuquerque, New Mexico

\section{Mary D. Nichols ${ }^{2}$}

Assistant Administrator for Air and Radiation

U.S. Environmental Protection Agency

Washington, D.C.

\section{Dr. Tara O'Toole}

Assistant Secretary for Environment

Safety and Health

U.S. Department of Energy

Washington, D.C.

James O. Payne, Jr.

Senior Litigator

Environmental Enforcement Section

Office of the Attorney General

State of Ohio

Columbus, Ohio

Gail Schoettler

Lieutenant Governor

State of Colorado

Denver, Colorado

\section{E. Ramona Trovato}

Director

Office of Radiation and Indoor Air

U.S. Environmental Protection Agency

Washington, D.C.

\section{Bruce G. Twining}

Manager, Albuquerque Operations Office

U.S. Department of Energy

Albuquerque, New Mexico

\section{Troy E. Wade II}

Wade Associates

Former Assistant Secretary for Defense Programs

U.S. Department of Energy

Las Vegas, Nevada

\footnotetext{
${ }^{2}$ Resigned on July 17, 1995; replaced by E. Ramona Trovato.
} 


\section{DR. JOHN F. AHEARNE}

John F. Ahearne is Executive Director of Sigma Xi, The Scientific Research Society, and Adjunct Scholar, Resources for the Future.

He received his Bachelor of Engineering (Physics) and MS from Cornell University, and an MA and PhD (Physics) from Princeton University. He served in the United States Air Force from 1959-1970 and resigned as Major. He then worked at the USAF Weapons Center on nuclear weapons effects and taught at the USAF Academy, Colorado College, and the University of Colorado (Colorado Springs). He served as Deputy and Principal Deputy Assistant Secretary of Defense from 1972-1977, and served in the White House Energy Office and as Deputy Assistant Secretary of Energy from 1977-1978. He was commissioner of the U.S. Nuclear Regulatory Commission from 1978-1983, and Chairman of the Commission from 1979-1981. Dr. Ahearne was Vice President and Senior Fellow, Resources for the Future, 1984-1989.

Chairman, National Research Council Committee on the Future of Nuclear Power

Development and Committee on Risk Perception and Communication

Co-chair, National Research Council Panel on Opportunities in Plasma Science and Technology

Member, National Research Council Committee on Nuclear Safety Research and National Academy of

Sciences Panel on Cooperation with the USSR on Reactor Safety

Member, National Research Council Board on Radioactive Waste Management

Member, National Research Council Committee on Technical Bases for Yucca Mountain Standards

Member, National Research Council Risk Assessment Visiting Committee

Member, National Research Council Committee on Risk Characterization

Member, Committee to Review Risk Management, Department of Energy's Environmental Restoration Program

Chair, U.S. Committee for International Institute for Applied Systems Analysis

Chairman, Secretary of Energy Advisory Committee on Nuclear Facilities Safety, 1988-1991

American Nuclear Society

Society of Risk Analysis

Sigma Xi, The Scientific Research Society

Fellow, American Association for the Advancement of Science

Fellow, American Academy of Arts and Sciences

Fellow, American Physical Society 


\section{GERARD F. SCANNELL}

Gerard F. Scannell joined the National Safety Council as President in 1995.

During 1992-1994, he was vice president, worldwide safety affairs, for Johnson \& Johnson, New Brunswick, N.J., and also served that firm 1979-1989 as director of corporate safety/fire/environmental affairs.

In 1989, Scannell was nominated by President Bush to be assistant secretary of labor for the Occupational Safety and Health Administration (OSHA). Earlier, he served in various positions at OSHA headquarters in Washington from 1971-1979 as director of the Office of Federal Agency Safety Programs, director of the Office of Standards and special assistant to the assistant secretary of labor for OSHA.

Other career positions include having been in safety management for: Rohm and Haas Co., Bristol, Pa; Thiokol Chemical Corporation, Bristol, Pa; and Aetna Casualty and Surety Co., Worcester, Mass.

He is a member of the Board of Directors of the National Fire Protection Association and chairs the National Fallen Firefighters Memorial Foundation.

Scannell graduated from the Massachusetts Maritime Academy with a Bachelor of Science Degree in 1955 and took postgraduate training in epidemiology and environmental economics at George Washington University. He served in the Navy as an explosive and nuclear weapons disposal officer from 1955 to 1958. In 1992, his alma mater conferred on him an Honorary Doctor of Public Administration.

He married Joanne Sullivan in 1956. They have five children and ten grandchildren. 


\section{ANDREW P. CAPUTO}

Andrew P. Caputo is Attorney for the Natural Resources Defense Council's Nuclear Program, Washington, D.C.

He received an $\mathrm{AB}$ with honors (History) in 1987 from Brown University. While at Brown, he served as the Vice Chairman, Advisory Committee on University Planning (the joint administration-faculty-student commitee that wrote Brown's yearly budget). He received a JD from Yale Law School in 1990. He was a member of the Moot Court Board and Senior Editor, Yale Law and Policy Review.

Attorney, Natural Resources Defense Council, Washington, D.C., July 1993 to present. Addresses issues relating to nuclear energy and nuclear weapons. Performs wide range of tasks, including legislative work, lobbying, litigation, administrative practice, and public education.

Attorney, Sierra Club Legal Defense Fund, Denver, Colorado, September 1990 to July 1993. Federal court litigator for public interest environmental law firm. Brought cases under the Endangered Species Act, the National Environmental Policy Act, the Clean Water Act, the Federal Land Policy and Management Act, the National Forest Management Act, the Freedom of Information Act, and the Adminstrative Procedure Act. Performed entire range of litigation tasks; investigated and shaped cases; drafted all manner of pleadings; engaged in discovery, including deposition; argued dispositive motions and examined witnesses in court. Dealt extensively with the press. 


\section{JOSEPH A. DEAR}

Joseph A. Dear is Assistant Secretary of Labor for Occupational Safety and Health.

Prior to his nomination to be Assistant Secretary, Dear was director of the Department of Labor and Industries in Washington State, where he was responsible for both workplace safety and health, and workers' compensation programs.

With the help of labor and management, Dear spearheaded a major reform of the workers' compensation program, converting a $\$ 225$ million deficit into a $\$ 350$ million surplus while stabilizing premiums for employers and improving benefits to workers at the same time. He also started health care cost containment and quality assurance programs. In 1992 the department's workers' compensation program received the Innovations in State and Local Government Award from the Ford Foundation and Harvard University.

Dear was president of the National Association of Governmental Labor Officials (NAGLO) in 1990-1991 and served on the board of directors for the Occupational Safety and Health State Plan Association (OSHSPA) from 1989-1993.

While serving as director of the Department of Labor and Industries, Dear also served as chairman of the State of Washington Investment Board which manages public pension portfolios and workers' compensation funds totaling more than $\$ 19$ billion.

Before joining the state government, Dear was research directory of the Washington State Labor Council from 1981-1985. He was the founder of People for Fair Taxes, a public interest coalition of labor, church and civic organizations supporting progressive state and local tax policy, and served as the organization's executive director from 1977 to 1981 .

Dear graduated from The Evergreen State College in Olympia, Washington, in 1976, with a Bachelor of Arts degree in political economy. He is a 1986 graduate of Harvard University's program for Senior Executives in State and Local Government offered through the John F. Kennedy School of Government.

Dear, 43 , is married and has two children. 


\section{JOSEPH JOHN DiNUNNO}

Joseph DiNunno is a Member of the Defense Nuclear Facilities Safety Board, a position he has held since August 13, 1992.

He began his professional career in 1942 with Westinghouse Electric Corporation in electrical engineering. Shortly thereafter, DiNunno joined the Department of the Navy, and for the next 17 years assumed increasingly responsible positions with the Bureau of Ships, the Naval Ordnance Laboratory and the Naval Reactors Branch of the Bureau of Ships/Atomic Energy Commission (AEC). At Naval Reactors, DiNunno served under Admiral H. G. Rickover as Project Officer for the nuclear power plant for the USS Long Beach (CGN7).

Upon transferring to the AEC in 1959, DiNunno became part of the regulatory staff that reviewed the safety aspects of design, construction and operation of nuclear reactors and a variety of uranium and plutonium processing facilities. In 1967, DiNunno was assigned to Paris as AEC's Scientific Representative where he performed technical liaison with atomic energy authorities in ten European countries, the Nuclear Energy Agency and the International Atomic Energy Agency. In 1969, DiNunno returned to AEC headquarters to head up AEC's first Office of Environmental Affairs.

From 1972 to 1983, DiNunno was employed by NUS Corporation. As Vice President and General Manager of the Environmental Safeguards Division, and later Technical Director of the Environmental Systems Group, he was responsible for engineering and environmental services provided to both industry and the government.

With the exception of two years of full-time employment with R.F. Weston (1986-1988) in support of DOE's Civilian Radioactive Waste Management Program, DiNunno continued his professional career parttime (1983-1992) as an independent consultant, providing environmental and nuclear safety services. His career included a number of years as a member of the Space Applications Board of the National Research Council and as a member of the Citizens' Advisory Panel on the Cleanup of Three Mile Island.

DiNunno has written extensively covering such issues as the safety of nuclear reactors and environmental considerations in power plant siting. He also has lectured on these topics at universities and industry seminars. DiNunno graduated with a Bachelor of Science in Electrical Engineering from Pennsylvania State University. In 1954, he earned a Master of Science in Electrical Engineering from the University of Maryland. In 1956-1957, he received training in nuclear engineering at the Oak Ridge School of Reactor Technology. 


\section{VICTOR A. FRANKLIN}

Victor A. Franklin is the Chief Environmental Counsel in the Westinghouse Electric Corporation Law Department where he is directly responsible for all environmental compliance and remediation issues including GOCO compliance for the corporation. In the GOCO area, Mr. Franklin has been a frequent lecturer at the DOE Westinghouse Environmental School of Excellence, and has worked on numerous significant environmental issues affecting the Department Of Energy complex.

At the DOE Fernald Site, where Mr. Franklin was General Counsel from January 1992 to December 1992, for Westinghouse, Mr. Franklin worked closely with the DOE management. Prior to his present position with Westinghouse, Mr. Franklin was a senior enforcement attorney with U.S. EPA Region V. In that capacity, he helped develop guidance documents regarding CERCLA and RCRA regulatory and enforcement issues as well as maintain responsibility for the case management of administrative and civil lawsuits brought under federal hazardous waste laws.

Prior to his work as an attorney, Mr. Franklin worked as a chemist which he finds useful in addressing complex legal and technical problems facing environmental issues today. Mr. Franklin received his Bachelors degree in chemistry from Illinois Wesleyan University and his Law degree from the University of Illinois. 


\section{DR. JERRY FREEDMAN}

Dr. Jerry Freedman is Deputy Assistant to the Secretary of Defense (Nuclear Matters).

He is a 1962 graduate of the University of New Mexico, where he received a Bachelor of Science degree in Mechanical Engineering. He then continued at the University of New Mexico, receiving a Master of Science degree in Mechanical Engineering in 1965. His PhD in Theoretical and Applied Mechanics was earned from Northwestern University, Evanston, Illinois, in 1971.

Dr. Freedman joined Sandia National Laboratories (SNL) in 1965 where he began working on the mechanical design and analysis of warheads in missiles. He then designed and fielded experiments for the nation's nuclear weapons testing program at the Nevada Test Site.

Dr. Freedman moved to the Department Of Energy's Headquarters at Germantown, Maryland, in 1978, where he formulated a national program, still used, for the transportation of radioactive materials and was instrumental in building a consensus with House and Senate staff members and representatives.

On his return to Sandia National Laboratories, Dr. Freedman held a number of positions of increasing responsibility. His work included the design of radioactive material transportation containers which comply with both Nuclear Regulatory Commission and International Atomic Energy Agency certification criteria. Additionally, he worked closely on radioactive waste transportation issues with the press and citizens groups on the Waste Isolation Pilot Plant Program.

Dr. Freedman was detailed to the Office of the Secretary of Defense from SNL in August, 1993, where he was head of an engineering team and was responsible for a nuclear standoff bomb, accident-resistant fissile material containers for both the Russian Federation and DOE, accident-resistant warhead containers for the U.S. and United Kingdom, characterization of weapon processes for proliferation analysis, and several other projects.

Dr. Freedman is a native of Houston, Texas, and is married to the former Mary Abernathy of Clinton, Kentucky. They have one daughter, Deborah. 


\section{BEVERLY E. C. GATTIS}

Ms. Beverly E. Gattis is President of Serious Texans Against Nuclear Dumping (STAND), a citizens' organization based in Amarillo, Texas.

A native of Amarillo, Ms. Gattis graduated from the University of Texas at Austin in 1973 with a BA in French and a minor in English.

Moving to Portland, Oregon, in 1976, she was an Assistant Buyer for Meier and Frank Department Stores. In 1978, she and her husband moved to Amarillo where she joined her family's five-store independent shoe business. From 1978-1985, she held the responsibilities of buyer and, for the last three years, many of the duties of General Manager. The family sold the stores to a public corporation in December, 1985.

Ms. Gattis joined STAND of Amarillo in 1985 after hearing a Department of Energy presentation about the civilian high-level nuclear waste repository being considered for Deaf Smith County, Texas. A life-long interest in environmental issues and science, plus a respect for clear language, convinced her that the public was neither being given straightforward information, and that the project was not technically sound or appropriate for the area. She was elected president of STAND in 1987, and has been re-elected to that position every year since.

In late 1990, when the Pantex Plant was obviously one site to which Rocky Flats plutonium operations might be moved, STAND took up issues involving the nuclear weapons complex for the first time. Knowing this would be a complicated and lengthy effort, STAND established permanent offices. In 1991, the board of directors appointed Beverly Gattis as Executive Director, a position which she continues to hold as a full-time volunteer.

Currently, Ms. Gattis serves as a member of the Pantex Plant Citizens' Advisory Board, and represents STAND in the Military Production Network -- a coalition of both grassroots and national organizations which address issues involving the nuclear weapons complex. She also served on the Potter and Randall County Local Emergency Planning Committee, on the Governor's Office preliminary committee to establish a Pantex citizens' advisory board, and on the advisory panel for the U.S. Congress Office of Technology Assessment study: Dismantling the Bomb and Managing the Nuclear Materials. 


\section{T. J. GLAUTHIER}

Since June 1993, Mr. T. J. Glauthier has served in the Clinton Administration's Office of Management and Budget as the Associate Director for Natural Resources, Energy and Science.

In that capacity, he and his staff serve as the key link between the Executive Office of the President and the agencies in these fields, which include the Departments of Agriculture, Interior, and Energy, the EPA, NASA, NSF, the Corps of Engineers and a number of smaller or independent agencies, such as the Smithsonian, the Kennedy Center, TVA, and others.

Mr. Glauthier is responsible for budget approval, legislative clearance and overall management oversight of these agencies. In that role he has chaired the White House team in the Vice President's reinventing government initiatives in these agencies. That produced the proposals in December, 1994 for major reforms in DOE and the Army Corps, and in the Spring of 1995 for strategic changes in NASA, Interior, EPA and Agriculture.

Major issues that Mr. Glauthier has dealt with in his OMB position, in addition to managing two full budget cycles, include the redesign of the space station, the closure of the Super Conducting Super Collider, emergency and long-term responses to the midwest floods of 1993, GATT, the 1995 Farm Bill, and numerous legislative proposals, such as Superfund, Drinking Water, National Parks and privatizing the U.S. Enrichment Corporation.

Prior to joining the Clinton Administration, Mr. Glauthier was Director of Energy and Climate Change at the World Wildlife Fund (WWF) for three years. He directed WWF's policy work in these areas and was also actively involved in technology transfer, the Biodiversity Convention, and the Earth Summit in Rio de Janiero in June of 1992.

Earlier, Mr. Glauthier spent twenty-three years in management consulting. For most of that time, he was with Temple, Barker \& Sloane, Inc., where he was the Vice President in charge of the firm's Public Policy and Management Group, and served as head of the firm's Washington, D.C. office. Initially focusing on corporate financial planning, he employed the same techniques for economic and policy analyses of environmental and other regulatory issues where government actions affect business. His clients included leading corporations, major trade associations, and government agencies.

Mr. Glauthier is a graduate of the Claremont Men's College and the Harvard Business School. 


\section{MARK A. GRIFFON}

Mark A. Griffon is a contract health physicist for the Oil Chemical Atomic Workers (OCAW) International Union. He is primarily involved in curriculum development under a National Institute of Environmental Health Sciences grant where he provides expertise in the areas of health physics and hazardous waste site cleanup. In addition to these responsibilities, he has also acted as a resource to the OCAW regarding health and safety, radiation safety, and regulatory analysis issues. He has provided technical support to OCAW since 1988.

In addition to his work with OCAW, Mark is also involved in providing environmental consultant services, specializing in all phases of radiation decontamination and decommissioning including: developing radiological characterization plans, developing Nuclear Regulatory Commission (NRC) approved remediation and decommissioning plans, developing health and safety plans, providing on-site health physics support, performing final status radiological surveys, and developing final status reports for the NRC. Mark is currently working in this capacity for Texas Instruments Incorporated where he has been involved in all aspects of a multi-million dollar decommissioning project over the past three years. Mark has worked as a consultant for several other organizations including: Textron Defense Systems, the Electric Power Research Institute, and the United States Peace Corps in Kazakhstan.

From 1989 to 1994, Mark was the Director of the Plan Enhancement Program for the Toxics Use Reduction Institute at the University of Massachusetts Lowell. He was responsible for coordinating a three-agency effort to assist Massachusetts industries with Toxics Use Reduction Planning. He was the director of an interagency steering committee consisting of the Massachusetts Office of Technical Assistance, the Massachusetts Department of Environmental Protection, and the Toxics Use Reduction Institute. As Director, Mark was responsible for the development of outreach materials and workshops, and the development of policy recommendations.

Mark was a project manager with the Technical Services Division of Chemical Waste Management from 1984 to 1986. Mark's primary responsibility was the coordination of on-site cleanup activities on government sites on the East coast. Specific responsibilities included: waste stream characterization, labpack preparation, coordinating shipments of hazardous waste, and preparing cost estimates for future cleanup jobs.

Mark holds a BS degree in Chemistry from Rennesslear Polytechnic Institute and an MS degree in 1990 from the University of Massachusetts. He is currently a $\mathrm{PhD}$ candidate in Industrial Hygiene at the University of Massachusetts. 


\section{DR. ANDREW C. KADAK}

Dr. Andrew C. Kadak is President and Chief Executive Officer of the Yankee Atomic Electric Company. In this capacity, he is responsible for overseeing all Yankee operations, including the decommissioning of the Yankee plant in Rowe, Massachusetts, and engineering services to the Vermont Yankee Nuclear Power Station, Maine Yankee, Seabrook and other clients worldwide.

The Yankee plant was built in 1957 and started commercial operation in 1960. Its 32 year record of safe and economic operation set a standard for the nuclear industry. The Yankee plant was permanently shut down by the owners in February 1992 and is being decommissioned.

Dr. Kadak has spent his entire career in the nuclear energy field. He graduated from Union College in 1967 and received his masters and doctorate degrees in Nuclear Engineering from Massachusetts Institute of Technology. He also received a masters degree in Business Administration from Northeastern University in 1983.

Dr. Kadak is quite active in the nuclear energy arena serving on many boards aimed at improving the technology, regulatory processes and solving problems of the industry. He is a member of the Board of Directors of the American Nuclear Society, the New England Council, the Nuclear Energy Institute and the Nuclear Waste Advisory Committee.

Yankee is presently decommissioning its nuclear power plant in Rowe, Massachusetts and is actively involved with the site clean-up criteria and restoration requirements with the Nuclear Regulatory Commission. 


\section{DR. C. JUDSON KING}

C. Judson King is the Vice Provost for Research of the University of California (UC) system and Professor of Chemical Engineering on the Berkeley campus. As such, he has responsibility for coordination of external and internal aspects of UC research. Included in these responsibilities are UC's programmatic interactions with, and scientific oversight of, the Lawrence Berkeley Laboratory; the Lawrence Livermore National Laboratory and the Los Alamos National Laboratory. He was formerly Provost for the Professional Schools and College, Dean of the College of Chemistry and Chair of the Department of Chemical Engineering, all on the Berkeley campus.

$\mathrm{He}$ is a member of the National Academy of Engineering, and has received the William $\mathrm{H}$. Walker, Warren K. Lewis and Clarence G. Gerhold Awards of the American Institute of Chemical Engineers; the Mac Pruitt Award of the Council for Chemical Research and the George Westinghouse Award of the American Society for Engineering Education. He is former Director of the American Institute of Chemical Engineers, Chair of the Council for Chemical Research and Chair of the Chemical Engineering Division of the American Society for Engineering Research, and founding Chair of the Separations Division of the American Institute of Chemical Engineers.

Dr. King chaired the National Research Council committee leading to the report "Separation and Purification: Critical Needs and Opportunities" (1987). Dr. King is the author of the textbook "Separation Processes", McGraw-Hill $(1971,1980)$. His research interests center around separations processes, presently spray drying and the use of reversible chemical complexation for recovery of polar organics (carboxylic acids, glycols, etc.) from aqueous solution. 


\section{MATTHEW LEIVAS, SR.}

Matthew Leivas, Sr., is Tribal Chairman and Chief Executive Officer of the Chemehuevi Tribe, Havasu Lake, California.

He served as a Tribal Council member from 1980 to 1983 and was Interim Tribal Chairman from April 1992 to 1993. In April of that year, he was elected to the Tribal Council and is serving a three-year term in his present position.

Mr. Leivas attended and completed the U.S. Indian Police Academy Training in Brigham City, Utah. He completed criminal justice courses from Weber State College in Ogden, Utah, and continued annual training offered by the Bureau of Indian Affairs, Law Enforcement Services and the Federal Law Enforcement Training Center at Marana, Arizona.

He was active in the promotion of Tribal Law Enforcement activities and is considered an expert on "Public Law 280". Mr. Leivas has worked with the Office of Criminal Justice and Planning with the state of California.

While serving as Chief Game Warden, he leased land from the Chemehuevi Tribe to develop a farming operation using the Tribe's existing water rights. Mr. Leivas has been a long-time advocate on water rights issues for Native Americans.

Mr. Leivas and his wife have two sons and a daughter and recently celebrated their twenty-first wedding anniversary.

Other activities and interests:

Anthropology and archeology

Native American fishing, hunting and gathering preservation and enforcement firearms instructor Native American Water Rights Coalition

Environment and wildlife protection and preservation

Revitalization of Chemehuevi native language and culture, song, dance and customs 


\section{DR. MILDRED McCLAIN}

Dr. Mildred McClain is Executive Director of Citizens for Environmental Justice, based in Savannah, Georgia.

Dr. McClain received her Bachelor's degree in English from the University of Massachusetts in 1973. She holds Masters of Arts degrees from the Harvard Graduate School of Education (in Education) and from Antioch Graduate School (in Educational Administration). Her Doctor of Education degree is from the Harvard Graduate School of Education where she was a candidate in Administration, Planning and Social Policy with a concentration in organizational development and educational administration.

Previous employment:

Teacher, Chatham Public Schools (Savannah), 1990-1993: provided instruction in English, World Culture and Citizenship.

Executive Director, Hands Across America of Georgia/Georgia Citizens Coalition on Hunger, 19871989: Supervised and coordinated the merging of these two community organizations; served as general administrator to the overall operation and its staff of eight.

Project Director, Georgia Citizens Coalition on Hunger, 1982-1987: Organized and trained low-income communities; developed and coordinated a comprehensive empowerment project for welfare recipients.

Director of the Learning Resource Center, Morris Brown College, 1984-1985: Planned, coordinated and schedules all activities in the Learning Resource Center; coordinated and supervised the Basic Skills Development Program (Reading, English, Math); taught Freshman Composition and remedial English for seniors; supervised three departments and a staff of 17.

Project Director, Florida Clearinghouse on Prisons and Jails, 1979-1981: Developed programs to serve incarcerated women, ex-offenders and their families.

Executive Director, Innovative Learning and Training Center, Inc., 1972-1978: Developed and managed a comprehensive community learning resources center.

Senior Consultant, Educational Enterprises, 1972-present: Consultant to various schools, organizations, businesses and national campaigns. 


\section{DR. JAMES MELIUS}

Dr. James Melius is the Scientific and Medical Director for the Center to Protect Workers' Rights, the research arm of the Building and Construction Trades Department of the AFL-CIO, Washington, D.C.

Dr. Melius attended Brown University receiving his AB in 1970 and his MMS in 1972. He graduated from the University of Illinois School of Medicine in 1974. Dr. Melius then completed residency training in family practice and occupational medicine and received board certification in both specialties. In 1984. he received a Dr. P.H. in Epidemiology from the University of Illinois School of Public Health.

From 1980 to 1987, Dr. Melius worked for the National Institute for Occupational Safety and Health (NIOSH) in Cincinnati, Ohio. Initially, he served as Chief of the Hazard Evaluations and Technical Assistance Branch. In 1985, he became Director of the Division of Surveillance, Hazard Evaluations and Field Studies, supervising the federal government's major occupational epidemiology program. While at NIOSH, Dr. Melius worked on a number of other activities including serving as Co-Chair of the Federal Committee on Indoor Air Quality and as a member of the team from the Centers for Disease Control which visited Bhopal, India immediately after the chemical plant disaster in 1984.

From 1987 until 1995, Dr. Melius worked for the New York State Department of Health. In 1988, he was appointed Director of the Division of Occupational Health and Environmental Epidemiology and in 1990, Professor of Environmental Health and Toxicology in the School of Public Health of the State University of New York at Albany. While in New York, Dr. Melius established a network of eight occupational health clinics throughout the state funded through workers' compensation premiums. He also directed the state's occupational and environmental epidemiology programs and played a major role in expanding the state's child lead poisoning prevention program. He also conducted research on occupational and environmental lead poisoning, environmental factors related to breast cancer, and cancer and birth defects related to exposure from hazardous waste disposal sites. He has served on several committees for the National Academy of Sciences and is currently on the National Electromagnetic Field Advisory Committee. He was also Chairman of the Technical Advisory Board for the Center to Protect Workers' Rights and of the Medical Advisory Board for the International Association of Fire Fighters. 


\section{MICHAEL H. MOBLEY}

Michael H. Mobley is Director of the Tennessee Division of Radiological Health, Nashville, Tennessee. Mr. Mobley has been with the Tennessee Radiation Control Program for over 25 years and has worked in every aspect of the Division's Radiation Control Program. He currently serves as Commissioner, appointed by the Governor (in 1984) to represent Tennessee on the Southeast Low-Level Waste Management Compact Commission, and as the State Liaison Officer for Tennessee to the Nuclear Regulatory Commission (Tennessee became an Agreement State in 1965; it was the seventh state to receive delegation by the Atomic Energy Commission [now the NRC] to regulate Atomic Energy Act radioactive material).

Mr. Mobley received a Bachelor of Arts Degree in Physics and Mathematics from Austin Peay University in 1968. In 1972, he received a Master of Science Degree in Physics from the University of Tennessee, and in 1983, earned a Master of Public Administration Degree from Tennessee State University. He is a 1986 graduate of the Tennessee Government Executive Institute.

Mr. Mobley is a past Chairperson of the Conference of Radiation Control Program Directors, Inc. (CRCPD); has served as that organization's Treasurer, and has served on numerous committees and working groups for the Conference. He is the current Chair of the Federal Facilities Committee, which has been charged by the CRCPD with developing and coordinating information regarding federal facility radiological impact issues. An additional charge is to assist state and federal agencies and programs in developing a comprehensive and consistent national state/federal radiation control program effort which would include federal facilities.

Mr. Mobley served on the Limited Scope Examination Committee of the American Registry of Radiologic Technologists. He has been involved in several national efforts concerning high-level radioactive waste involving the U.S. Department of Energy and the U.S. Nuclear Regulatory Commission. He is also an active member of the Health Physics Society. 


\section{DR. THOMAS E. MURLEY}

Dr. Thomas E. Murley is a consultant based in Potomac, Maryland. He received a BS in Engineering Mechanics (Highest Honors) from the University of Illinois in 1961. His ScD in Nuclear Engineering is from the Massachusetts Institute of Technology, 1965

Professional Experience:

1975 - 1994 United States Nuclear Regulatory Commission:

Director of Nuclear Reactor Regulation, 1987-1994: Responsible as the licensing official for implementing NRC's policies of safety oversight of all commercial nuclear power plants in the United States.

Regional Administrator, Region I, 1983-1987

Director, Regional Operations and Generic Requirements Staff, Office of Executive Director for Operations, 1981-1983

Director, Division of Safety Technology, 1980-1981

Deputy Director and Director, Division of Reactor Safety Research, 1975-1980

1968 - 1975 Unites States Atomic Energy Commission

Assistant Project Manager, Clinch River Breeder Project, 1974-1975

Technical Assistant to Commissioner W.O. Doub, 1972-1974

Senior Reactor Engineer, Core Design Branch, 1968-1972

1966 - 1968 Westinghouse Electric Corporation - Senior Scientist, Fast reactor design.

1965 - 1966 Karlsruhe Nuclear Research Center, Germany - Post-doctoral research on fast reactor physics.

Professional Activities:

Adjunct Associate Professor of Nuclear Engineer, Catholic University, 1969 - 1975. Taught graduate courses in Nuclear Engineering and Safety. Supervised a Ph.D. thesis on void production in metals irradiated by fast neutrons.

Member and Past Chairman, Board of Directors, OECD Halden Reactor Project, 1979-1983

Fellow of American Nuclear Society, 1987

Member and Vice Chairman, Committee on Nuclear Regulatory Activities, OECD Nuclear Energy Agency, 1987-1994 


\section{ROBERT H. NEILL}

Robert H. Neill is Director of New Mexico's Environmental Evaluation Group (EEG), a position he has held since its creation in 1978. The EEG performs an independent evaluation of the potential public health and environmental impact to New Mexico of the Waste Isolation Pilot Plant (WIPP) Project. Prior to this, he served as a commissioned officer in the Bureau of Radiological Health of the U.S. Public Health Service for 23 years.

Mr. Neill received the degree of Mechanical Engineer from the Stevens Institute of Technology and an MS in Radiation Hygiene from the Harvard University School of Public Health.

\section{Affiliations and Committees:}

U.S. Representative, International Atomic Energy Agency visiting seminar on environmental radiation to Latin America

Chairman, Radiological Health Section, American Public Health Association

Member, National Academy of Sciences Panel on Uranium Mill Tailings

Member, Advisory Panel on DOE Generating Sites Environmental Cleanup, Office of Technology Assessment, U.S. Congress

Member, Advisory Panel on Nuclear Weapons Dismantlement, Office of Technology Assessment, U.S. Congress

Member, EPA Advisory Committee on C-14

Member, EPA Advisory Committee on Implementing WIPP Land Withdrawal Act

Temporary Advisor, World Health Organization, Health Impacts of Different Energy Sources

Temporary Advisor, World Health Organization, Health Effects of High-Level Wastes

Member, Technical Advisory Committee on MRS, State of Tennessee

Consultant, High Level Waste Task Force, Sierra Club

Member, Institutional/Environmental Review Group, Crystalline Rock Project, Battelle National Laboratory 


\section{DR. TARA O'TOOLE}

Dr. Tara O'Toole was nominated by President Clinton to be Assistant Secretary for Environment, Safety and Health for the U.S. Department of Energy (DOE) on June 7, 1993. She was confirmed by the United States Senate on October 8, 1993.

Dr. O'Toole is the principal advisor to the Secretary of Energy regarding environment, safety, and health policies and oversight at Department of Energy sites and facilities, including effective oversight of the Department's safeguards and security policies. She is also responsible for providing liaison with other federal agencies concerning development of applicable environment, safety and health regulations and implementing an effective occupational health program, which includes epidemiological studies and medical monitoring of the DOE workforce.

Prior to her appointment to DOE, Dr. O'Toole served as Senior Analyst for the Congressional Office of Technology Assessment (OTA). In this position, she was the project director of an occupational safety and health program study requested by the Senate. The evaluation resulted in a background paper titled, Hazards Ahead: Managing Cleanup Worker Health and Safety at the Nuclear Weapons Complex. She was also a principal analyst and contributing author to the 1991 OTA report Complex Cleanup: The Environmental Legacy of Nuclear Weapons Production. This assessment, conducted at the request of the Senate Committee on Armed Services, evaluated environmental restoration and waste management programs at the Department of Energy's Nuclear Weapons Complex. Dr. O'Toole was responsible for those aspects of the report dealing with the potential off-site health impacts of the contamination from DOE facilities.

She was an instructor in the Departments of Internal Medicine and Preventive Medicine at the University of Maryland Medical School. She was also an attending physician in the University's occupational health care clinic where she taught medical students and residents.

Dr. O'Toole received a BA degree from Vassar College and a MD degree from the George Washington University. She completed her residency in internal medicine at Yale and received a Masters in Public Health and training in occupational and environmental medicine at the Johns Hopkins University.

She is a member of the American Public Health Association, the American Occupational and Environmental Medicine Association, and the Society for Occupational and Environmental Health. 


\section{JAMES O. PAYNE, JR.}

Jim Payne is an Assistant Attorney General in the Environmental Enforcement Section of the Ohio Attorney General's Office, Columbus, Ohio. He represents Ohio in environmental litigation, including actions involving the U.S. Department of Energy and other sites with radioactive waste and pollution. He wrote an 18-state amicus brief relied on by the U.S. Supreme Court in New York v. US when it struck the Take Title Provision from the Low-Level Radioactive Waste Policy Amendments Act of 1985 on state sovereignty grounds. He has given Congressional testimony on three occasions on applying environmental laws to radioactive waste and pollution. One of the occasions was the March 1, 1994 hearing on the Federal Nuclear Facilities Licensing and Regulation Act, where he testified in support of a task force to recommend how to end self-regulation of DOE. He also spoke at "Controlling the Atom in the 21st Century," a retreat for Congressional staffers on reform of nuclear regulation led by the Natural Resources Defense Council in December 1992.

Jim has been active with the National Association of Attorneys General, where he co-chaired the Atomic Energy Work Group. This group produced a resolution, passed unanimously by NAAG, which calls on Congress to apply environmental laws to radioactive waste and pollution. Jim is acting co-chair of the NAAG/DOE Work Group, which seeks consensus on emerging environmental compliance and legislative issues. In September 1994, Jim co-wrote a monograph published by NAAG entitled Radioactive Materials, Waste and Pollution: A Guide for States and a Proposal for Legislation.

Jim received his law degree from Ohio State University College of Law, and an AB from Dartmouth College. 


\section{GAIL SCHOETTLER}

Gail Schoettler (pronounced SHET-ler), Democrat, is Lieutenant Governor of Colorado, elected in 1994. Previously, she served 2 terms as Colorado State Treasurer, managing the state's $\$ 2.5$ billion investment portfolio, and was president of the Douglas County School Board of Education and trustee for the University of Northern Colorado.

Lieutenant Governor Schoettler was one of the key organizers of the Women's Bank, founded in 1978, and served on its Board of Directors for nine years. She also served on the board of Equitable Bankshares of Colorado, a bank holding company, and chaired the board of Equitable Bank of Littleton. In 1982, Governor Richard Lamm appointed her to his cabinet as Executive Director of the Colorado Department of Personnel, managing 27,000 employees and a $\$ 500$ million payroll.

For 10 years she served as board chairman of the Denver Children's Museum, and has served as president of the National Women's Forum and Women Executives in State Government. She serves on the Boards of Directors for Mi Casa Women's Resource Center, National Jewish Center for Immunology and Respiratory Medicine, and the Douglas County Educational Foundation.

Lieutenant Governor Schoettler grew up on a cattle ranch in Shandon, California. She received an economics degree with honors from Stanford University and a doctorate in history from the University of California at Santa Barbara. She moved to Colorado more than 25 years ago. She is married to Dr. Donald Stevens, Managing Director for the Institute of International Business at the University of Colorado at Denver. She has three children: Lee, Tom and Jim, and lives in Parker.

\section{Honors:}

University of California at Santa Barbara Distinguished Alumni Award (1988)

Big Sisters of Colorado, Salute to Women Award (1987)

Leadership Denver Association, Outstanding Alumni Award (1986) 


\section{E. RAMONA TROVATO}

Ramona Trovato is the Director, Office of Radiation and Indoor Air in the Office of Air and Radiation, U.S. Environmental Protection Agency (EPA).

Ms. Trovato has served with the EPA in various technical and managerial positions since 1973. She has also served as the Director of the Water Enforcement Division, Director of Ground Water Protection Division, and National Environmental Services Office. For 13 years she served in EPA Region 3 as a chemist, team leader for the inorganic chemistry laboratory and quality assurance manager for the Chesapeake Bay Program.

Ms. Trovato has been recognized for her achievement in management and leadership and currently co-chairs the EPA Human Resources Council, chairs the Ad Hoc Panel and State/EPA Focus Group on National Environmental Laboratory Accreditation, and serves on the EPA Executive Resources and Awards Boards. 


\section{BRUCE G. TWINING}

Bruce G. Twining is Manager of the U.S. Department of Energy's (DOE) Albuquerque Operations Office, Albuquerque, New Mexico.

Appointed to this position in March 1988, Mr. Twining is responsible for field coordination and direction of the nation's nuclear weapons efforts including the stockpile stewardship, and energy research and development programs; the Waste Isolation Pilot Plant; Environmental Restoration and Waste Management activities at several sites; and the Uranium Mill Tailings Remedial Action Project.

Prior to his current position, he served as DOE's Acting Deputy Assistant Secretary for Nuclear Materials, Office of Defense Programs (August 1987 to March 1988) and as Deputy Manager of DOE's Savannah River Operations Office in Aiken, South Carolina (1984 to 1987).

Other assignments included Assistant Manager for Energy Research and Technology in DOE's San Francisco Operations Office (June 1982 to December 1984), and Project Manager of the Mirror Fusion Test Facility Project (November 1977 to May 1982).

Mr. Twining began his federal career by participating in the Atomic Energy Commission Intern and Fellowship programs. He held various positions in government reactor development and magnetic fusion research programs (June 1964 to November 1977).

Mr. Twining is a 1968 honor graduate in engineering from California Polytechnic State University, San Luis Obispo, California. In 1970, he earned a master's of science degree in nuclear engineering from the University of Washington in Seattle, Washington, and in 1982 received a master's of business administration degree from St. Mary's College in Moraga, California.

Mr. Twining and his wife Becky have two children, Kimberly and Scot. 


\section{TROY E. WADE II}

Troy E. Wade II is Owner and President of Wade Associates, an executive management consulting firm in Las Vegas, Nevada.

He received his Bachelor's degree in Mechanical Engineering from the University of Colorado at Boulder.

President and Chief Executive Officer, International Disarmament Corporation (IDC), Washington, D.C., 1992-present: IDC participates in the planning and implementation of the major disarmament initiatives currently under discussion between the U.S. and the Commonwealth of Independent States (formerly the Soviet Union).

President, AWC, Las Vegas, Nevada, 1990-1992: AWC is a Lockheed Company set up to do environmental remediation.

Research Professor, George Washington University, Washington, D.C., 1989-1991.

Director of National Security Studies, Institute for Technology and Strategic Research, The George Washington University, 1989-1990.

Assistant Secretary of Energy for Defense Programs, Department of Energy, Washington, D.C., 19871989: The defense programs complex included 15 facilities located in 12 states involving over 60,000 people with a 1989 budget in excess of $\$ 8$ billion.

Principal Deputy Assistant Secretary of Energy for Defense Programs, Department of Energy, Washington, D.C., 1987

Director, Idaho National Engineering Laboratory, Department of Energy, 1983-1987: Responsible for state-of-the-art research, development and demonstration in the areas of nuclear materials production, radioactive waste management, nuclear reactor safety and emerging energy technologies.

Principal Deputy Assistant Secretary of Energy for Defense Programs, Department of Energy, Washington, D.C., 1981-1983 


\section{Appendix C}

\section{DOE Nuclear Facilities and Sites}




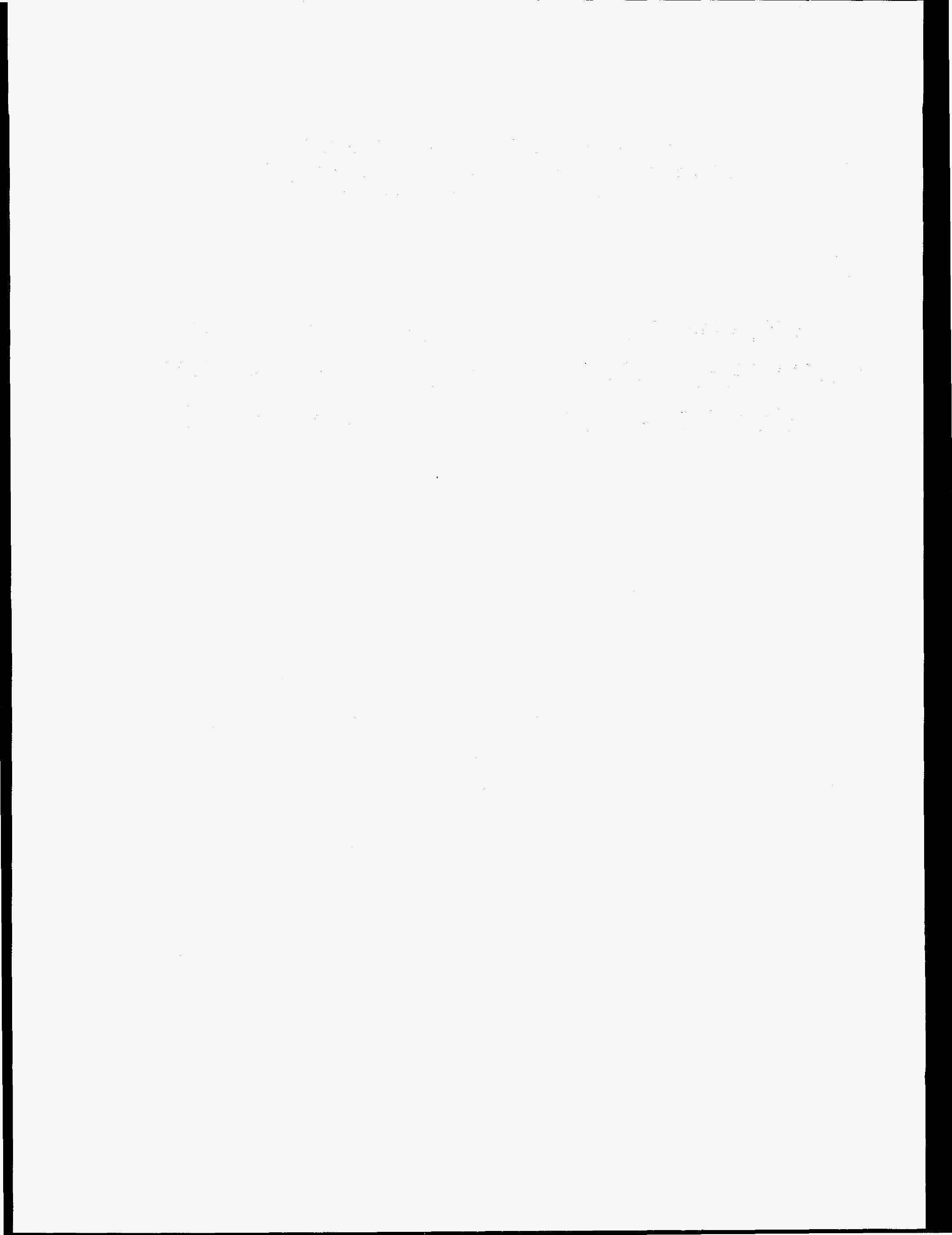




\section{COMPENDIUM OF DOE NUCLEAR / RADIOLOGICAL FACILITIES AND AREAS: CURRENT AND POSSIBLE FUTURE}

Background Report for the Advisory Committee on External Regulation of DOE Nuclear Safety

February 1995 



\section{REPORT 1: COMPENDIUM OF DOE NUCLEAR/RADIOLOGICAL FACILITIES AND SITES: PRESENT AND POSSIBLE FUTURE}

\section{THIS REPORT WAS PREPARED UNDER THE AUSPICES OF THE DOE INTERNAL WORKING GROUP.}

Lead Responsibility: the Office of the Associate Deputy Secretary for Field Management, Office of Field Services and Liaison, and the technical staff of the Advisory Committee on External Regulation of DOE Nuclear Safety.

Contributing Authors: the Office of the Assistant Secretary for Defense Programs, Deputy Assistant Secretary for Facility Transition and Technical Support, Office of Special Projects; the Office of the Assistant Secretary for Environmental Management, Office of Strategic Planning and Analysis; the Office of the Deputy Assistant Secretary for Waste Management, Office of Program Integration, Technical Analysis Division; the Office of the Deputy Assistant Secretary for Environmental Restoration, Office of Program Integration, Management Systems Division; the Office of the Deputy Assistant Secretary for Transition and Management; the Office of Energy Research, Office of Environmental, Safety, and Health Technical Support, Safety and Health Division; and the Office of Nuclear Energy, Office of Civilian Reactor Development, Facilities Division. 



\section{TABLE OF CONTENTS}

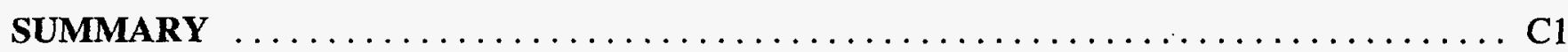

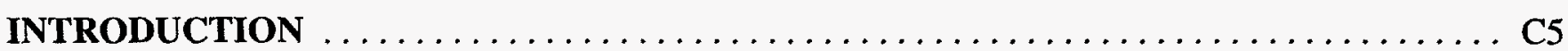

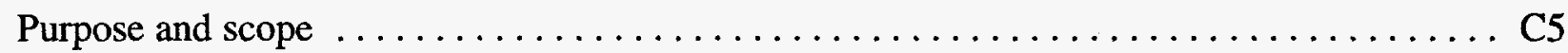

Background Description of Department of Energy Missions $\ldots \ldots \ldots \ldots \ldots \ldots \ldots$ C7

I. NUCLEAR WEAPONS/NATIONAL SECURITY $\ldots \ldots \ldots \ldots \ldots \ldots \ldots \ldots \ldots$

Functional Mission and Evolution of the Mission $\ldots \ldots \ldots \ldots \ldots \ldots \ldots \ldots \ldots$ C9

Major Facilities - Historical Perspective $\ldots \ldots \ldots \ldots \ldots \ldots \ldots \ldots \ldots \ldots \ldots \ldots \ldots \ldots \ldots \ldots \ldots$

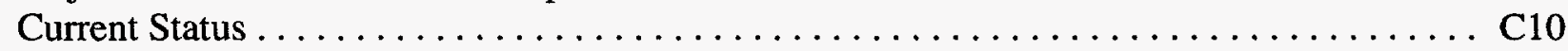

Future of Major Facilities $\ldots \ldots \ldots \ldots \ldots \ldots \ldots \ldots \ldots \ldots \ldots \ldots \ldots \ldots \ldots \ldots \ldots \ldots, \mathrm{C} 11$

II. NON-DEFENSE TEST AND RESEARCH NUCLEAR REACTORS $\ldots \ldots \ldots \ldots \ldots$ C17

Functional Mission $\ldots \ldots \ldots \ldots \ldots \ldots \ldots \ldots \ldots \ldots \ldots \ldots \ldots \ldots \ldots \ldots, \mathrm{C} 17$

Major Facilities - Historical Perspective $\ldots \ldots \ldots \ldots \ldots \ldots \ldots \ldots \ldots \ldots \ldots \ldots \ldots \ldots \ldots \ldots \ldots \ldots \ldots \ldots$

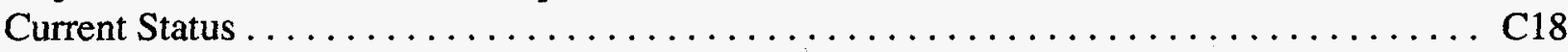

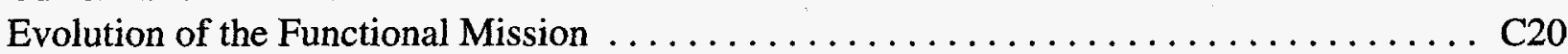

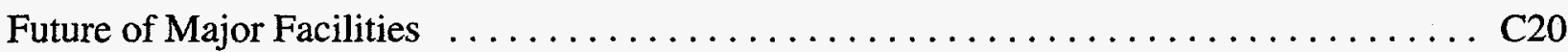

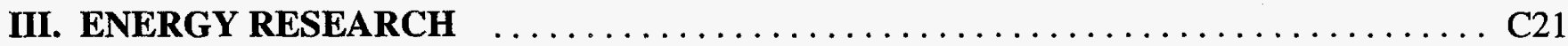

Functional Missions of Energy Organizations $\ldots \ldots \ldots \ldots \ldots \ldots \ldots \ldots \ldots \ldots \ldots \ldots \ldots \ldots \ldots$

Major Facilities - Historical Perspective $\ldots \ldots \ldots \ldots \ldots \ldots \ldots \ldots \ldots \ldots \ldots \ldots \ldots \ldots \ldots \ldots \ldots \ldots, 23$

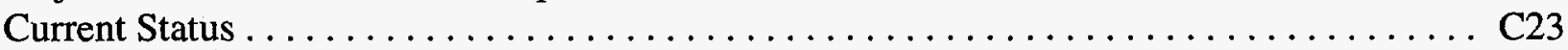

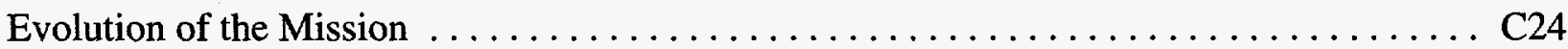

Future of Major Facilities $\ldots \ldots \ldots \ldots \ldots \ldots \ldots \ldots \ldots \ldots \ldots \ldots \ldots \ldots \ldots \ldots \ldots, C 24$

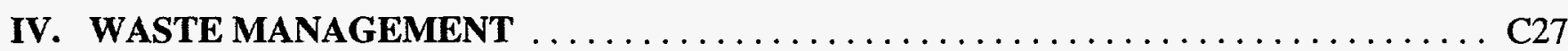

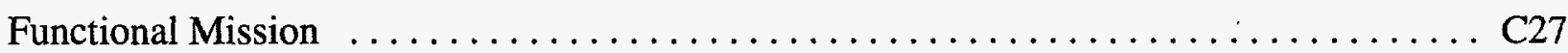

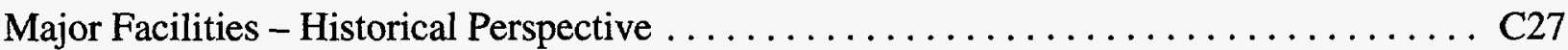

Current Status . . . . . . . . . . . . . . . . . . . . 28

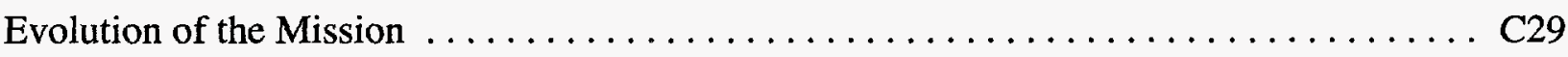

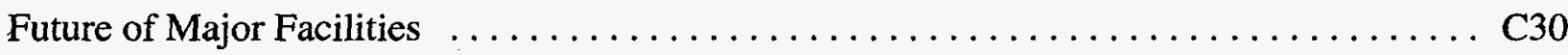

V. ENVIRONMENTAL RESTORATION $\ldots \ldots \ldots \ldots \ldots \ldots \ldots \ldots \ldots \ldots \ldots \ldots \ldots \ldots \ldots \ldots \ldots \ldots$ C31

Functional Mission $\ldots \ldots \ldots \ldots \ldots \ldots \ldots \ldots \ldots \ldots \ldots \ldots \ldots \ldots \ldots, \mathrm{C} 31$

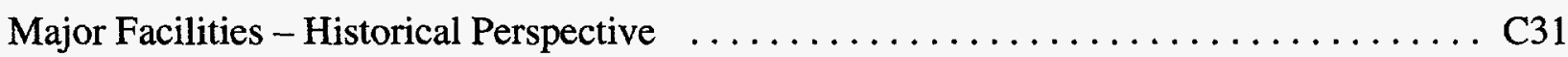

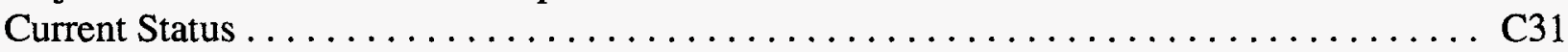

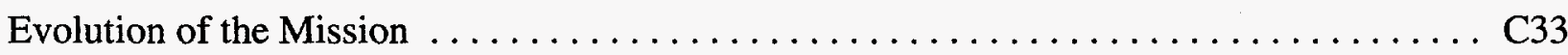

Future of Major Facilities $\ldots \ldots \ldots \ldots \ldots \ldots \ldots \ldots \ldots \ldots \ldots \ldots \ldots \ldots \ldots \ldots$, C33

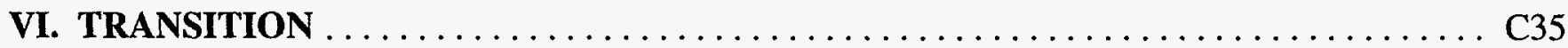




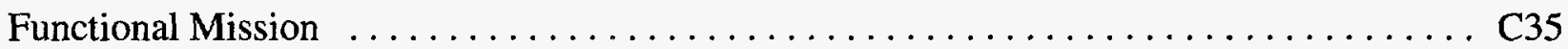

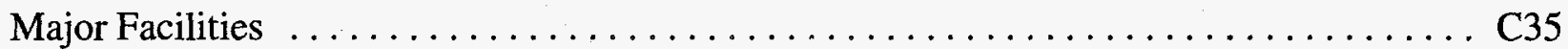

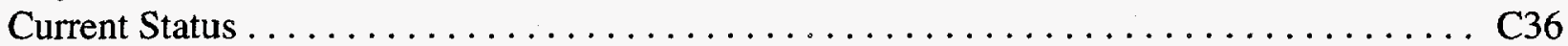

Evolution of the Functional Mission $\ldots \ldots \ldots \ldots \ldots \ldots \ldots \ldots \ldots \ldots \ldots \ldots \ldots$

VII. NUCLEAR MATERIAL MANAGEMENT $\ldots \ldots \ldots \ldots \ldots \ldots \ldots \ldots \ldots \ldots \ldots \ldots$ C37

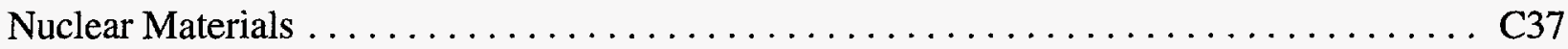

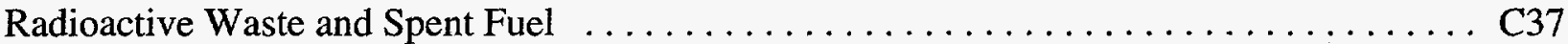

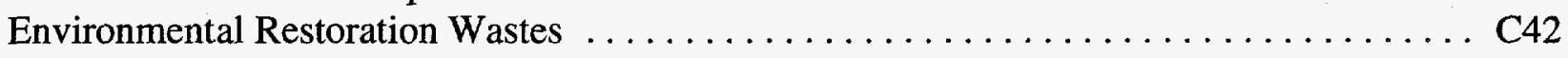




\section{COMPENDIUM OF DOE NUCLEAR / RADIOLOGICAL FACILITIES AND AREAS PRESENT AND POSSIBLE FUTURE}

\section{SUMMARY}

For the past 50 years, the Department of Energy and its predecessor agencies have been charged with the responsibility for the research, development, testing, and production of nuclear weapons. In addition, the Department has been responsible for the conduct of non-weapons research and development activities to support the demonstration of commercial nuclear reactor technology, as well as conducting fundamental research in energy sources, natural and physical sciences, including high-energy and nuclear physics, magnetic fusion, medicine, and materials development. These activities have generated a legacy of facilities, sites, and nuclear materials that the Department must manage.

With the conclusion of the Cold War, the Department finds that it must manage a major evolution in these previous responsibilities, as well as deal with the environmental legacy resulting from these previous efforts. While many of the nuclear and radiological facilities will continue to operate, many other facilities must now be decommissioned and dismantled. Sites occupied by Department of Energy operations must undergo varying levels of environmental cleanup, and the Department must continue to responsibly administer large inventories of spent reactor fuel and radioactive wastes. The missions and organization of the Department have been revised to address these emerging changes.

Currently, the Department manages some 34 individual sites with about 3,500 nuclear and radiological facilities in 13 States, encompassing more than 85 million square feet of building space. The spectrum of these facilities is extensive and includes nuclear research and production reactors, nuclear weapon assembly/disassembly facilities, chemical processing facilities, nuclear material storage vaults, reactor fuel fabrication facilities, tritium recovery facilities, particle accelerators, and research laboratory facilities.

The substantial nuclear material inventories managed by the Department are composed of:

- more than 430 metric tons of fissile and non-fissile radioactive materials and isotopes,

- about 2,700 metric tons heavy metal of spent reactor fuel, and

- more than 1.9 million cubic meters of radioactive waste.

In the conduct of site and building decommissioning and environmental restoration, the Department is estimating contaminated inventories of about:

- 800 million cubic meters of ground water,

- 60 million cubic meters of contaminated soil,

- 12 million cubic meters of solid media, and

- 7 million cubic meters of rubble and debris.

The defense mission of the Department is undergoing a radical change. This effort is shifting from a production effort to one that will focus primarily on the dismantlement of nuclear weapons, management 
of the radioactive materials resulting from weapon dismantlement, stewardship of the remaining nuclear arsenal, maintenance of the nuclear weapon technology infrastructure, and non-proliferation activities. With few exceptions, all production facilities have been shutdown. These efforts are expected to be concentrated at the Pantex Plant and at the three weapon laboratories: Los Alamos National Laboratory, Lawrence Livermore National Laboratory, and National Laboratory.

The non-defense test and research reactor mission has also experienced a significant reduction in scope. This effort has shifted from the research and development of commercial reactor technology to efforts associated primarily with the U.S. Naval Propulsion Program, and the operation of six research reactors and other facilities in support of other departmental missions such as medical research and isotope production. These efforts will be concentrated primarily at Brookhaven National Laboratory, Oak Ridge National Laboratory, Idaho National Engineering Laboratory, and Sandia National Laboratory.

The energy research mission of the Department is not expected to experience a major reduction. Efforts in the areas of high energy and nuclear physics, basic energy sciences, biological and environmental sciences, and fusion energy are expected to continue. These endeavors are expected to be accomplished primarily through the use of Office of Nuclear Energy facilities (research reactors); the 12 large accelerators; and the 5 multipurpose laboratories that include Oak Ridge National Laboratory, Lawrence Berkeley Laboratory, and Brookhaven National Laboratory.

The Department's waste management and the environmental restoration missions are expected to continue to increase in scope as the transition of additional facilities to the decommissioning and dismantlement phase continues. The management of these various facilities prior to the initiation of decontamination and decommissioning efforts will be an expanding role.

The waste management efforts include managing about 2,650 metric tons of spent reactor fuel, the majority of which is located at the Hanford, Idaho National Engineering Laboratory, and Savannah River sites. This mission involves managing the treatment, storage, and disposal of substantial inventories of radioactive waste. Key radioactive waste inventories include:

- $\quad 398,450$ cubic meters of high-level waste,

- $\quad 344,190$ cubic meters of transuranic and transuranic mixed wastes, and

- $\quad 265,640$ cubic meters of low-level and low-level mixed wastes.

These wastes are primarily located at the following sites:

- $\quad$ High-Level Waste: Hanford Site, Idaho National Engineering Laboratory, Savannah River Site, and at West Valley Demonstration Project.

- Transuranic and Transuranic Mixed Wastes: Idaho National Engineering Laboratory, Oak Ridge facilities, Savannah River Site, Los Alamos National Laboratory, and Hanford Site.

- Low-Level and Low-Level Mixed Wastes: Nevada Test Site, Rocky Flats Environmental Technology Site, Oak Ridge facilities, Savannah River Site, Los Alamos National Laboratory, and Hanford Site 
The environmental restoration effort now encompasses over 130 sites in 33 States and 1 territory in Puerto Rico. This involves some 850 efforts, including 320 at National Priorities List sites; 80 other Comprehensive Environmental Response, Compensation, and Liability Act activities, commonly called Superfund projects; 97 Resource Conservation and Recovery Act closures; 108 Resource Conservation and Recovery Act corrective actions; 156 decontamination and decommissioning projects; 24 Uranium Mill Tailings Remedial Action Project sites; and 46 Formerly Utilized Sites Remedial Action Program sites. 


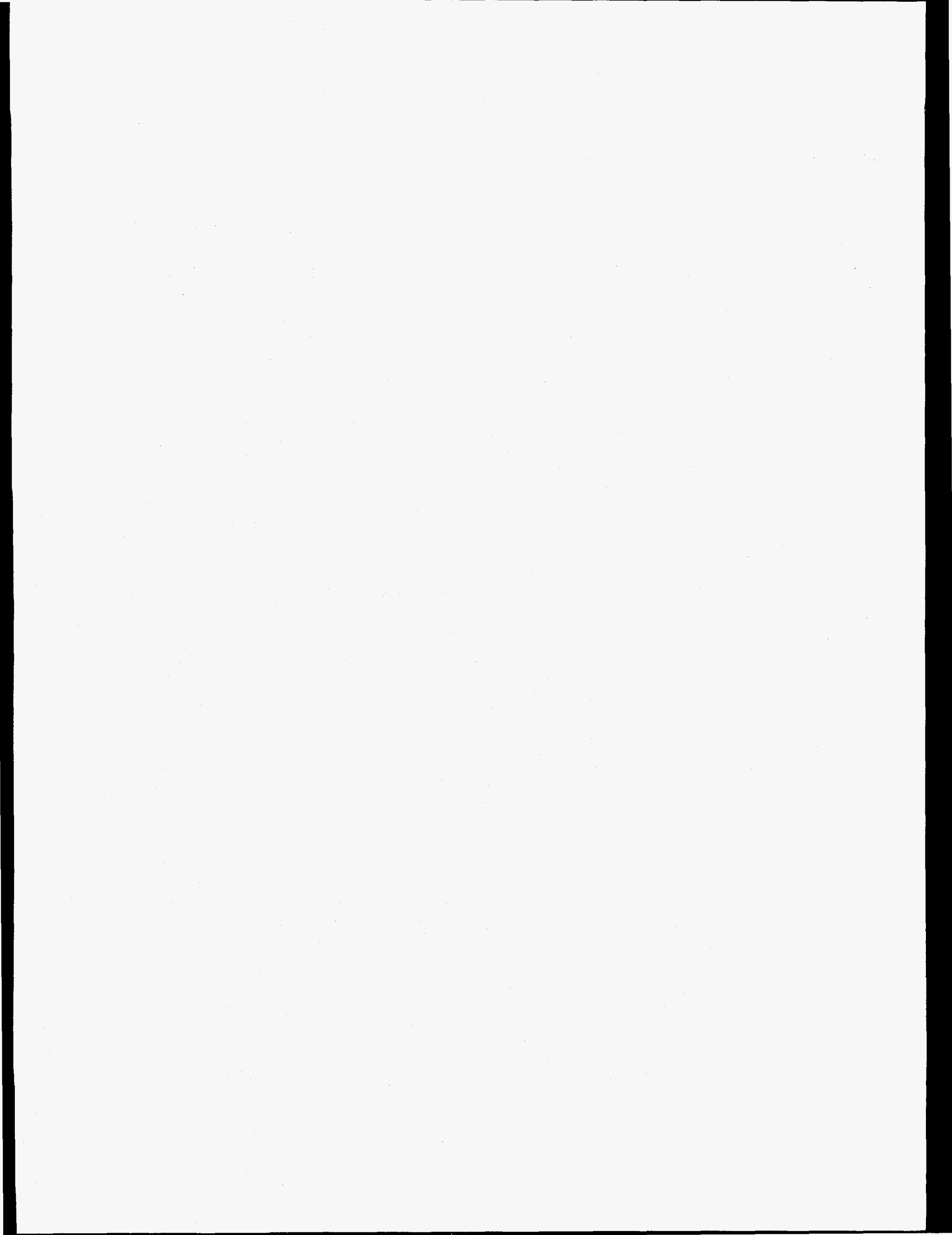




\section{INTRODUCTION}

The U.S. Department of Energy, a successor executive agency to the U.S. Atomic Energy Commission and the U.S. Energy Research and Development Administration, owns and operates a diverse collection of about 3,500 nuclear and radiological research and development, testing, processing, and production facilities and sites. Located in geographically dispersed locations across the United States, these facilities are housed at various sites that encompass about 2.1 million acres. These facilities include nuclear research and production reactors, nuclear weapon assembly/disassembly facilities, chemical processing facilities, nuclear material storage vaults, reactor fuel fabrication facilities, tritium recovery facilities, particle accelerators, and research laboratory facilities. These encompass about 85 million square feet of facility space.

The Department's defense and non-defense missions have resulted in a substantial inventory of radioactive material. This material is present in various forms, such as fissile and non-fissile nuclear material (enriched uranium, depleted uranium, plutonium, and other isotopes in various physical forms); spent nuclear reactor fuel; sealed sources; and radioactive wastes. In summary, these materials represent a sizeable inventory to be managed by the Department.

\section{Purpose and scope}

This report provides a consolidated synopsis of the various facilities and operations conducted by the Department of Energy. It reviews the conditions that caused the need for the wide assortment of facilities and provides the status and projected intended future use of these facilities. To enable the reader to understand the context for future facility use and operations, the report describes evolutionary changes occurring in the Department's mission and addresses the types of, and general inventories of, the primary nuclear materials at these facilities or sites.

To help the reader understand the many Department of Energy facilities, various site/installation facilities have been aggregated into major facility types. These facility types and the basis for their current and future operational status are described in Appendix A. The variety of nuclear materials has been grouped into major material categories.

For application in this report, a nuclear/radiological facility is:

A facility or operation (activity) that involves radioactive materials or sources such that a radiological hazard, or a perceived radiological hazard, exists or potentially exists to workers, the public, or the environment.

The above definition includes machinery and sources that emit ionizing radiation, and includes all operations conducted on or offsite by the Department. In this report, a "site" refers to a geographically distinct Department of Energy property that bounds several facilities and operations.

The various nuclear facilities are also described by their respective Nuclear Hazard Category. This index provides a relative indication of the nuclear and hazardous material hazard represented by the nuclear 
material inventories and operations performed in a particular facility under unmitigated release sequences. The Nuclear Hazard Categories are summarized as follows: ${ }^{1}$

- $\quad$ Category 1 - The hazard analysis for this facility shows the potential for the release of significant quantities of nuclear materials that could threaten members of the public who are offsite, or the offsite environment.

- $\quad$ Category 2 - The hazard analysis for this facility shows the potential for the release of significant quantities of nuclear materials that could threaten workers at adjacent facilities, members of the public who would be onsite, or the onsite environment.

- $\quad$ Category 3 - The hazard analysis for this facility shows no potential for the release of significant quantities of nuclear materials that could threaten workers at adjacent facilities, the public, or the environment onsite or offsite. Only workers, the public, or the environment in the immediate local area of the hazard are threatened.

Due to their low inventories of nuclear material, the form in which the nuclear material is present, or the type of operations, radiological facilities are discussed in general in the respective chapters. ${ }^{2}$ Refer to Appendix C.

The precise accounting of facilities as presented in this report may differ from those in other published Department reports. Any differences are primarily due to differences in how the individual buildings or structures, or portions of buildings and structures, and support buildings/structures may be counted or sorted into various categories. In addition, the precise definition of aggregate groups of facilities can vary. The primary basis for the definition of facilities, as represented in this report, was based on the definition provided above and on the process utilized by the various Program Offices in defining the facilities to which the requirements of DOE Orders 5480.23 Nuclear Safety Analysis Reports, 5480.22 Technical Safety Requirements, and 5480.21 Unreviewed Safety Questions and the corresponding draft Price Anderson Amendments Act phase 1 Code of Federal Regulation rules would apply. The discussion in this report covering nuclear materials is not intended to be all inclusive. This chapter is designed to provide a representative picture of the types, amounts, and forms of nuclear material managed by the Department. The Office of Policy, Planning and Program Evaluation is current developing a nationwide baseline report on the facilities and materials under the auspices of the U.S. Department of Energy. This Baseline Material Inventory Report will discuss onsite and offsite facilities, sites, and nuclear materials in detail and is expected to be completed within the next few months.

1 For a discussion of hazard categories, refer to the DOE standard DOE-STD-1027-92, Hazard Categorization and Accident Analysis Techniques for Compliance with DOE Order 5480.23, Nuclear Safety Analysis Reports, December 1992.

2 For a discussion on radiological facility designation, see DOE standard DOE-EM-STD5502-94, Hazard Baseline Documentation, August 1994. 


\section{Background Description of Department of Energy Missions}

Beginning in the late 1940's and continuing through today, the Department of Energy and its predecessor agencies have constructed, operated, and administered an extensive variety of facilities. These facilities have been typically associated with a primary mission assigned to the Department in legislation or by executive order. Each of these missions has several common functional aspects such as research and development, nuclear material processing and management, and facilities management. The Department's initial missions focused on national security (the development, testing, production, and maintenance of nuclear weapons); non-defense test and research nuclear reactors (the development, demonstration, construction, and operation of commercial nuclear reactor technology); and energy research (the development of basic sciences, and the development and application of fossil and alternate energy resource technology). These historical missions were and are managed within the Department by means of mission program offices that include the Office of Defense Programs; the Office of Nuclear Energy; and the Offices of Energy Research, Fossil Energy, and Energy Efficiency and Renewable Energy, respectively.

The Department's functional missions encompassed the production of significant quantities of special nuclear materials, such as plutonium, and other radioactive materials. In recent years, the recognition of the importance of environmental protection has resulted in two new charges to the Department of Energy that are designed to address the environmental legacy generated by these historical Departmental missions. The Environmental Restoration and Waste Management missions embody strong commitment to the management of various wastes and contaminated properties that may represent risks to human health and the environment. These efforts are dealing with such diverse issues as the decontamination and decommissioning of surplus facilities, the management of radioactive and other wastes at over 137 sites nationwide, and the remediation of contaminated soil and ground water on or surrounding these sites. These emerging missions are managed by the Office of Environmental Management and the Office of Civilian Radioactive Waste Management. 

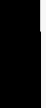


\section{NUCLEAR WEAPONS/NATIONAL SECURITY}

The present Department of Energy mission of Nuclear Weapons/National Security is managed by two offices. The Office of Defense Programs is responsible for the administration of activities and facilities associated with the research and development, testing and certification, production, maintenance, and dismantlement of nuclear weapons. Non-proliferation and arms control are the responsibilities of the Office of Non-proliferation and National Security. These responsibilities require maintaining a strong research and development base (part of which had been formerly devoted to Office of Defense Programs efforts), cooperating with other nuclear nations in the maintenance of nuclear technology and material controls, and developing solutions to problems created by threats to peace, the public health, and the environment.

\section{Functional Mission and Evolution of the Mission}

The mission of Nuclear Weapons/National Security is divided into five primary areas that include:

- dismantlement of nuclear weapons,

- $\quad$ stewardship of the remaining U.S. nuclear weapons arsenal,

- maintenance of the nuclear weapon technology infrastructure,

- $\quad$ downsizing of the nuclear weapon complex, and

- $\quad$ non-proliferation and arms control.

Each of these areas has several objectives supported by certain facilities.

The dismantlement of nuclear weapons is a major activity under which major production and assembly facilities have been transformed into major storage and disassembly sites. While managing the dismantling of the U.S. nuclear arsenal, the Office of Defense Programs is also assisting former Cold War opponents in the reduction of their arsenals and in the control and storage of special nuclear materials.

Stewardship activities are directed at assuring confidence in the existing stockpile, while it is being rapidly reduced, and maintaining the ability to respond to threats that might evolve in the future. This stewardship must be accomplished under a continuing program of reduction in the number of supporting facilities.

Technology maintenance is the effort to conserve nuclear weapons design and manufacturing capability at an advanced level of technology, though production is not continuing. New solutions addressing elements of nuclear weapon design, production, and maintenance that caused environmental, safety, and health concerns will further enhance nuclear safety and environmental protection.

The downsizing of the nuclear weapon complex is already well underway. Many former production facilities have been shut down both before and following the end of the Cold War. These facilities are being transferred to the Office of Environmental Management to facilitate their decontamination, decommissioning, and dismantlement. 


\section{Major Facilities - Historical Perspective}

The elements of the Office of Defense Programs' mission have changed drastically in the past few years since the end of the Cold War, although the rates of weapon production had been slowed well before the breakup of the Soviet Union. In the 1950's and 1960's, production capacity was expanded at a rapid rate. At one time, 14 production reactors at Hanford and Savannah River were operating to manufacture plutonium and tritium. Various facilities for chemical processing, component manufacturing, assembly, testing, and research were typically built in duplicate to ensure continued capability in case of attack. The huge gaseous diffusion plant for uranium enrichment at Oak Ridge (K-25) was built in triplicate, with additional plants at Paducah, Kentucky, and Portsmouth, Ohio. Several laboratories (Los Alamos National Laboratory, Lawrence Livermore National Laboratory, and Sandia National Laboratory) were created for the research, development, design, and bench-scale and field scale testing of weapons components. Research reactors were, and are today, needed to investigate the physics of nuclear reactions and their effects on weapons components, as well as materials research.

To provide the needed nuclear material, uranium mines and ore-processing facilities were developed. Fluorination facilities (to convert uranium to the gaseous form necessary for the enrichment process) were built at Fernald, Ohio, and Weldon Spring, Missouri, to provide the metal form of uranium. Enrichment plants, such as K-25 at Oak Ridge, Tennessee, were constructed to concentrate the needed uranium isotopes. Fabrication facilities were constructed to form and embellish special nuclear materials into the optimum shapes for employment as fuel elements, targets, or weapons parts. Nuclear reactors to produce plutonium were constructed and placed in operation. Various nuclear component manufacturing facilities (including Y-12 at Oak Ridge, Tennessee, and the Rocky Flats Plant in Colorado) and high-explosive component and nuclear weapon assembly and maintenance plants (such as Pantex Plant in Amarillo, Texas) were constructed. Production facilities (such Kansas City Plant, Kansas City, Missouri, and Mound Plant, Miamisburg, Ohio) were constructed to provide the electrical, electronic, mechanical and electromechanical, and small explosive components. Nuclear test facilities (Nevada Test Site) were built to prove the efficacy of weapons design and confirm the explosive yield. The locations of these various facilities are illustrated in Figure 1. Few of these facilities are functioning today.

\section{Current Status}

Los Alamos National Laboratory, Sandia National Laboratory, and Lawrence Livermore National Laboratory are operating to maintain the technical base of the U.S. nuclear arsenal and assist in the achievement of the objectives mentioned earlier. The plutonium and tritium production reactors (at the Hanford and Savannah River sites) have been shut down. The Plutonium Finishing Plant, a chemical fuel processing facility at Hanford, is nearing final shutdown. This plant is the last Office of Defense Programs facility at that site. The canyons at Savannah River ( $F \& H$ ) are converting solutions of transuranic isotopes of americium, curium, and plutonium and processing stored spent reactor fuel into solid forms suitable for storage. The Tritium Facility at Savannah River continues to reprocess the contents of tritium reservoirs to remove the accumulated decay helium. The Pantex Plant in Amarillo, Texas, is focusing on the dismantlement of nuclear weapons and serving as a storage facility for the disassembled materials.

Production operations at the Rocky Flats Plant have been terminated, and the site is now engaged in environmental restoration. The Rocky Flats Plant remains a major storage facility for plutonium materials 
that were in process or present as waste forms at the time production operations were shut down. The Oak Ridge Y-12 Plant serves as the primary storage center for highly enriched uranium removed from nuclear weapons and returned from foreign nations. A significant portion of the gaseous diffusion plant at Oak Ridge, which was closed in the 1980's, is being leased to a private corporation to provide enrichment services to the electrical power utility companies that operate power reactors. Many plants used for the processing and fabrication of nuclear fuels have been closed down and are undergoing environmental restoration. The existing ban on nuclear testing has resulted in the closing of test site complexes in Nevada and in the Pacific. The Defense Program's role in Nevada is primarily stewardship of inactive facilities.

With the shutdown of the production reactors, no Category 1 (high hazard) facilities remain under the Office of Defense Programs. Currently, the Office of Defense Programs has responsibility for 77 Category 2 (moderate hazard) and 83 Category 3 (low hazard) nuclear facilities and various low-hazard radiological facilities.

\section{Future of Major Facilities}

The few facilities expected to remain under the Office of Defense Programs include those at Oak Ridge, Savannah River, Pantex, Rocky Flats (storage of weapons plutonium only), Hanford, and the three national laboratories noted above. As of January 30, 1995, all Savannah River facilities other than the Tritium Facility will be turned over to the custody of the Office of Environmental Management. Under present and anticipated future budget restrictions imposed upon the Department, the construction of additional facilities will be limited. The Office of Defense Programs will require three types of new or expanded facilities to accomplish its assigned mission. The first type of facility is related to the conduct of nuclear weapon research without the benefit of nuclear testing. The proposed National Ignition Facility at Lawrence Livermore National Laboratory is an example of such a facility. The second future need is an expansion of secure storage capacity for the special nuclear material (plutonium, highly enriched uranium, etc.) resulting from the dismantlement of nuclear weapons. Such facilities could be needed at locations such as Pantex Plant and the Oak Ridge Y-12 Plant. The third type of facility is critical for the maintenance of the nuclear arsenal. This is a facility for the production of tritium gas. The Department has various studies underway to examine these future facility needs.

The Office of Defense Programs' mission is one of the Department's elements that is undergoing radical changes. For this reason, a more detailed discussion of the current status and future purpose of the Office of Defense Programs' facilities and nuclear safety hazards is presented. 
Office of Defense Programs: Major Facilities

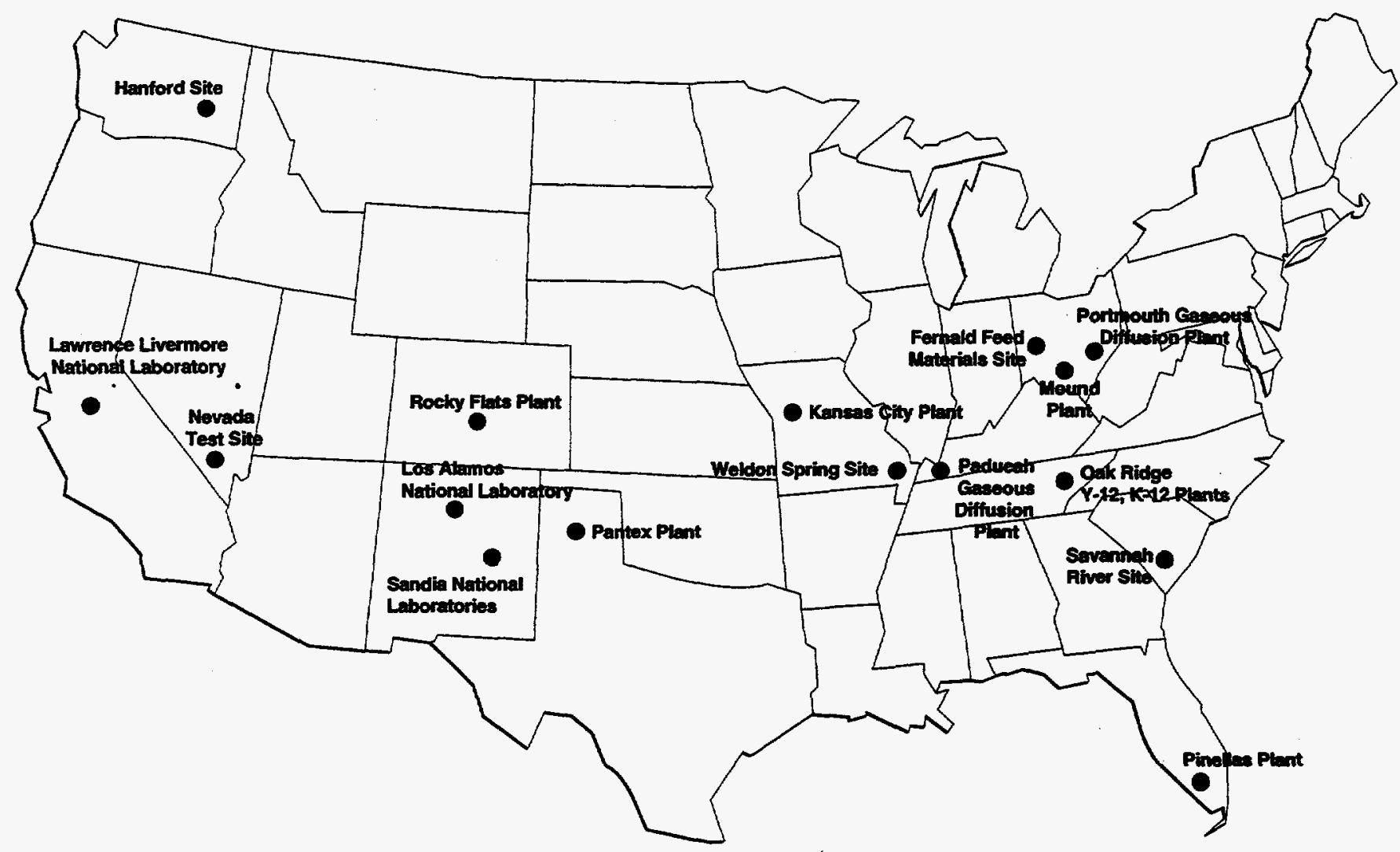

\section{Oak Ridge Facilities}

The Y-12 Plant at Oak Ridge will have the primary functions described in Table 1. The decreased level of activity associated with the drawdown of the U.S. nuclear arsenal leaves storage as the only function not experiencing a substantial reduction in activity. Oak Ridge has become the primary facility for the storage of highly enriched uranium. Shipments of highly enriched uranium packed and transported from UstKamenogorsk in Kazakhstan were added to the inventory at this facility.

\begin{tabular}{||l|l|l||}
\hline \multicolumn{3}{|c|}{ Table 1. OAK RIDGE FACILITIES (Y-12 PLANT) } \\
\hline FACILITY FUNCTION & \multicolumn{1}{|c||}{ STATUS } & \multicolumn{1}{c|}{ HAZARD FORMS } \\
\hline $\begin{array}{l}\text { Highly Enriched Uranium } \\
\text { Processing }\end{array}$ & $\begin{array}{l}\text { Active at reduced rate in solvent } \\
\text { extraction process }\end{array}$ & $\begin{array}{l}\text { Uranium processed as nitrate, } \\
\text { stored as less reactive oxide or } \\
\text { metal, criticality }\end{array}$ \\
\hline
\end{tabular}




\begin{tabular}{||l|l|l|}
\hline Highly Enriched Uranium Storage & Expanding with increased need & $\begin{array}{l}\text { Uranium stored primarily in metal } \\
\text { form, criticality }\end{array}$ \\
\hline Weapon Part Certification & $\begin{array}{l}\text { Verification of content of parts in } \\
\text { storage }\end{array}$ & $\begin{array}{l}\text { Uranium stored as disassembled } \\
\text { parts, criticality }\end{array}$ \\
\hline $\begin{array}{l}\text { Fabrication of Uranium } \\
\text { Components }\end{array}$ & $\begin{array}{l}\text { Casting-pressing- } \\
\text { machining }\end{array}$ & $\begin{array}{l}\text { Uranium metal in form in which } \\
\text { worked, criticality }\end{array}$ \\
\hline
\end{tabular}

\section{$\underline{\text { Savannah River Facilities }}$}

The Savannah River facilities will have the primary functions described in Table 2. F and $\mathrm{H}$ Canyons have been repositories for large quantities of various isotopes of transuranic elements ( $\mathrm{Am}, \mathrm{Cm}, \mathrm{Np}, \mathrm{Pu}$ ) that are now in the early stages of being removed from solution and processed into forms suitable for long-term storage. In addition, these facilities will be employed to process spent reactor fuel from various sources stored at the Savannah River Site. The Tritium Facility has an ongoing two-fold mission that involves (1) removing the decay products in the tritium reservoirs of those weapons remaining in the nuclear arsenal and, with the cessation of production reactor operation, (2) providing a source of "pure" tritium. Because this isotope of hydrogen is also required for the initiation of fusion reactions, a new source will eventually be necessary. A key methodology currently under consideration uses an accelerator(s) to produce the required quantities.

\begin{tabular}{|l|l|l|}
\hline \multicolumn{3}{|c|}{ Table 2. SAVANNAH RIVER FACILITIES } \\
\hline \multicolumn{1}{|c|}{ FACILITY } & \multicolumn{1}{|c|}{ FACILITY FUNCTION } & \multicolumn{1}{c|}{ HAZARD FORMS } \\
\hline F Canyon and H Canyon & $\begin{array}{l}\text { Reprocessing of spent fuel and } \\
\text { transuranic material to storable solids }\end{array}$ & $\begin{array}{l}\text { Oxides and other forms of Uranium, } \\
\text { Plutonium and other fission or decay } \\
\text { products }\end{array}$ \\
\hline Tritium Facility & $\begin{array}{l}\text { Reprocessing of tritium to remove } \\
\text { decay products }\end{array}$ & Tritium as gas and as metal tritides \\
\hline Savannah River Technology Center & $\begin{array}{l}\text { Conduct research and experiments to } \\
\text { support Savannah River activities }\end{array}$ & Research dependent \\
\hline
\end{tabular}

\section{Rocky Flats Plant Facilities}

At the Rocky Flats Plant, storage of plutonium is the only Office of Defense Programs function now and for the foreseeable future. The quantity of plutonium stored is approximately 13 metric tons. Most of the site is under the auspices of the Office of Environmental Management for cleanup.

\section{$\underline{\text { Pantex Plant Facilities }}$}

The Pantex Plant, which formerly assembled the various components of the nuclear weapons and qualified them for addition to the nuclear arsenal, has now become the disassembly facility. The primary types of facilities employed at Pantex are described in Table 3. 


\begin{tabular}{||l|l|l||}
\hline \multicolumn{3}{|c|}{ Table 3. PANTEX FACILITIES } \\
\hline FACILITY GROUP & FACILITY FUNCTION & HAZARD FORMS \\
\hline $\begin{array}{l}\text { Assembly-Disassembly Cells and } \\
\text { Bays }\end{array}$ & Disassembly of nuclear weapons & $\begin{array}{l}\text { High explosives, highly enriched } \\
\text { uranium and plutonium metal, } \\
\text { tritium, criticality }\end{array}$ \\
\hline Magazine Storage & $\begin{array}{l}\text { Nuclear weapon storage under } \\
\text { Department of Energy control }\end{array}$ & High explosives, tritium, criticality \\
\hline Richmond Igloos & Storage for disassembled pits & Criticality \\
\hline SAC Magazines & $\begin{array}{l}\text { Nuclear weapon storage under } \\
\text { Department of Defense control }\end{array}$ & High explosives, tritium, criticality \\
\hline Test Facilities & $\begin{array}{l}\text { Testing weapons components to } \\
\text { verify quality, shelf stability }\end{array}$ & High explosives, tritium \\
\hline
\end{tabular}

\section{Hanford Facilities}

The Plutonium Finishing Plant is the last remaining Office of Defense Programs facility at Hanford. This plant is designed to complete the chemical processing of the plutonium produced in the Hanford production reactor complex before its shipment to Rocky Flats for fabrication. Once the last plutonium residues have been processed into a form suitable for interim storage, operations at the Plutonium Finishing Plant will be ended, and action is currently underway to transfer this facility to Office of Environmental Management. The major hazard at the Hanford Site is the millions of gallons of waste that were produced by production reactors and chemical processing plants and accumulated during their years of operation.

\section{$\underline{\text { National Laboratory Facilities }}$}

Sandia National Laboratory, Los Alamos National Laboratory, and Lawrence Livermore National Laboratory are the Office of Defense Programs sites most concerned with achievement of the priority objectives of the Department of Energy's National Security Strategic Plan. These objectives include maintenance of the nuclear weapon technology infrastructure and core competencies, and the research and development technical and analytical bases. In addition, the sites will continue efforts to improve nuclear weapon technology without an underground nuclear test program. Assignments include endeavors with the scientists of other nations to reduce the threat of nuclear arms to the world as a whole. Key Office of Defense Programs facilities at the national laboratories are listed in Tables 4 through 6.

\begin{tabular}{||l|l|l||}
\hline \multicolumn{3}{|c|}{ Table 4. SANDIA NATIONAL LABORATORY } \\
\hline FACILITY GROUP & FACILITY FUNCTION & HAZARD FORMS \\
\hline Pulsed Reactors (2) & Continuing scheduled experiments & $\begin{array}{l}\text { Reactor-produced radiation and } \\
\text { fission products }\end{array}$ \\
\hline
\end{tabular}




\begin{tabular}{||l|l|l||}
\hline Annular Core Research Reactor & $\begin{array}{l}\text { Conversion to Molybdenum-99 } \\
\text { Production }\end{array}$ & $\begin{array}{l}\text { Reactor-produced radiation and } \\
\text { fission products }\end{array}$ \\
\hline Critical Assembly & Continuing scheduled experiments & Criticality produced radiation \\
\hline Gamma Irradiation & Continuing scheduled experiments & Fission products and Cobalt-60 \\
\hline Hot Cells & $\begin{array}{l}\text { Storage and examination of } \\
\text { irradiated test materials }\end{array}$ & $\begin{array}{l}\text { Radiation from fission products } \\
\text { and neutron activation }\end{array}$ \\
\hline Particle Beam Fusion Facility & Conducting fusion research & Radiation, chemicals \\
\hline $\begin{array}{l}\text { Nuclear Materials Storage and } \\
\text { Radiation Standards }\end{array}$ & $\begin{array}{l}\text { Serves as radiological machine } \\
\text { shop }\end{array}$ & Radiation \\
\hline
\end{tabular}

\begin{tabular}{||l|l|l||}
\hline \multicolumn{3}{|c|}{ Table 5. LOS ALAMOS NATIONAL LABORATORY } \\
\hline FACILITY GROUP & FACILITY FUNCTION & HAZARD FORMS \\
\hline Omega West Reactor (TA-2) & Shut down with fuel removed & Small residual contamination \\
\hline $\begin{array}{l}\text { Chemistry/Metallurgy Research } \\
\text { (TA-3-29) }\end{array}$ & $\begin{array}{l}\text { Analytical uranium chemistry/ } \\
\text { plutonium metallurgy }\end{array}$ & Uptake of toxic chemicals \\
\hline $\begin{array}{l}\text { LAMP/LANCE } \\
\text { (TA-53) }\end{array}$ & $\begin{array}{l}\text { Medium energy laser and neutron } \\
\text { scattering center }\end{array}$ & $\begin{array}{l}\text { High-energy radiation, X-rays, } \\
\text { neutrons }\end{array}$ \\
\hline Plutonium Facility (TA-55) & $\begin{array}{l}\text { Plutonium processing, weapons } \\
\text { research and development, } \\
\text { plutonium research and } \\
\text { development waste treatment }\end{array}$ & $\begin{array}{l}\text { Toxic chemical and radiation } \\
\text { effects of Special Nuclear Material }\end{array}$ \\
\hline $\begin{array}{l}\text { Weapons (TA-16) Engineering } \\
\text { Test Facility }\end{array}$ & $\begin{array}{l}\text { Tritium processing, purifying, } \\
\text { packaging }\end{array}$ & Tritium \\
\hline $\begin{array}{l}\text { Critical Experiment Facility (TA- } \\
\text { 18) }\end{array}$ & $\begin{array}{l}\text { Tech facilities for defense, nuclear } \\
\text { materials research }\end{array}$ & $\begin{array}{l}\text { Radiation from criticality, fission } \\
\text { products }\end{array}$ \\
\hline $\begin{array}{l}\text { Office of Defense Programs Site } \\
\text { East } \\
\text { (TA-21) }\end{array}$ & Tritium science and fabrication & Tritium \\
\hline
\end{tabular}




\begin{tabular}{||l|l|l||}
\hline \multicolumn{3}{|c|}{ Table 6. LA WRENCE LIVERMORE NATIONAL LABORATORY } \\
\hline FACILITY & CURRENT STATUS & HAZARD FORMS \\
\hline Heavy Elements Facility & Study of nuclear chemistry & Radioactive actinides \\
\hline $\begin{array}{l}\text { High Explosives Application } \\
\text { Facility. }\end{array}$ & $\begin{array}{l}\text { Research and test of high } \\
\text { explosives }\end{array}$ & High explosives \\
\hline $\begin{array}{l}300 \text { Area complex Buildings } 801 \\
\text { \& 851 }\end{array}$ & $\begin{array}{l}\text { Investigating phenomena of } \\
\text { radiation interactions }\end{array}$ & $\begin{array}{l}\text { Hazard is explosive releases of } \\
\text { energy, little radioactivity }\end{array}$ \\
\hline $\begin{array}{l}\text { Plutonium Facility } \\
\text { Plutonium research and } \\
\text { development (metallurgical } \\
\text { chemistry) }\end{array}$ & $\begin{array}{l}\text { Uptake of plutonium and its } \\
\text { chemical compounds }\end{array}$ \\
\hline Tritium Facility & Tritium research and development & Tritium \\
\hline NOVA Laser Facility & Performing fusion research & $\begin{array}{l}\text { Hazard is high energy, not } \\
\text { radioactivity }\end{array}$ \\
\hline
\end{tabular}




\section{NON-DEFENSE TEST AND RESEARCH NUCLEAR REACTORS}

\section{Functional Mission}

The Office of Nuclear Energy is responsible for the operation of the Department's non-defense test and research reactors. The current and projected program requirements for the Department's non-defense test and research reactors are categorized into six major areas.

Materials Irradiation: Materials exposed to irradiation undergo changes that affect their structural properties. Therefore, it is essential that materials planned for use in a neutron environment be tested. This research provides data that is vital to ensuring the safety and reliability of materials selected for use in fission and fusion applications.

Fuels Testing: Specific fuel element designs are subjected to conditions of normal operation, expected operational transients, various levels of burnup, severe conditions of transient overpower, and loss of cooling. This testing is conducted to determine fuel behavior, predict margins of safety with specific fuelelement designs, and validate the various analytical tools used in final design. This research is vital in providing data for design of efficient reactor cores that meet safety and reliability goals.

Neutron Scattering: Neutrons of various energy levels are used to analyze the relationship between molecular structure and physical properties of materials, such as high temperature superconductors, magnetic materials, metal alloys, polymer gels, and biological materials. The tests are conducted external to the reactor core utilizing beam tubes.

Activation Analysis: Following the exposure of sample materials to radiation and their activation, gamma ray spectroscopic analysis of the decaying isotopes identifies elemental composition of the sample to detect impurities or contaminants.

Medical Research: The use of neutron beams to evaluate and develop treatments for tumors in humans.

Isotope Production: Isotope targets are placed in the reactor's high neutron flux to produce radioactive sources used in research, industrial radiography, and medical diagnostic and therapy procedures, and to produce plutonium-238 for space and defense applications.

\section{Major Facilities - Historical Perspective}

The Department's non-defense test and research reactors are classed as Category A and Category B facilities depending upon the thermal-power rating of the reactor. Category A reactors, listed in Appendix B, are operated at a power level at or above 20 megawatts thermal and are classified as Category 1 (high hazard) facilities. Category B reactors, listed in Appendix B, are operated at power levels below 20 megawatts and are classified as Category 2 (moderate hazard) facilities. The Department's non-defense test and research reactor facilities are generally defined to include the nuclear reactor and heat transport systems, spent-fuel storage facilities, and general plant support facilities. The major Office of Nuclear Energy facilities are illustrated in Figure 2. 
There are currently three Category A non-defense reactors in operation and two in transition to permanent shutdown. The reactors that are operating in support of the Department's missions include the High Flux Beam Reactor at the Brookhaven National Laboratory, the High Flux Isotope Reactor at the Oak Ridge National Laboratory, and the Advanced Test Reactor at the Idaho National Engineering Laboratory. The Fast Flux Test Facility, located at the Hanford Reservation near Richland, Washington, and the Experimental Breeder Reactor-II, located at the Argonne National Laboratory-West in Idaho, are currently being defueled as those facilities are transitioned to radiologically and industrially safe shutdown conditions.

The Department's operating Category B non-defense reactors include the Brookhaven Medical Research Reactor at the Brookhaven National Laboratory, the Neutron Radiography Reactor Facility at the Argonne National Laboratory-West, and the Advanced Test Reactor Critical Facility at Idaho National Engineering Laboratory.

\section{Current Status}

The Department's non-defense reactors are operating in support of clearly defined missions and are expected to continue to operate well into the next century. The High Flux Beam Reactor and the High Flux Isotope Reactor operate primarily in support of the missions of the Office of Energy Research.

The High Flux Beam Reactor began operation in 1965 and operates at a power level of 30 megawatts. This reactor uses a highly enriched uranium fuel and a heavy water moderator. It supplies intense beams of thermal neutrons for neutron-scattering experiments in a variety of basic research applications in physics, chemistry, materials science, and biology. In addition, the reactor provides irradiation facilities for neutronactivation analysis, radiation-damage studies, and isotope production for experimental and medical purposes.

The High Flux Isotope Reactor began operation in 1966 and operates at a power level of 85 megawatts. This reactor is fueled with highly enriched uranium oxide. It supplies neutrons for neutron-scattering experiments in a variety of basic research applications in physics, chemistry, and biology. In addition, the reactor provides irradiation facilities for testing fuels and materials. The High Flux Isotope Reactor is also used for the production of californium-252, iridium-192, and other isotopes for research, industrial, and medical applications.

The Advanced Test Reactor began operation in 1969 primarily in support of the U.S. Naval Nuclear Propulsion Program. This 250-megawatts, water-cooled reactor is designed to study the effects of intense radiation on samples of reactor materials, including fuels. The aluminum-clad fuel is highly enriched uranium. The Advanced Test Reactor produces a neutron flux that simulates long-duration radiation effects on materials and fuels used in the U.S. Naval Nuclear Propulsion Program. The reactor is also used for production of isotopes used in medicine, research, and industry. The Advanced Test Reactor Critical Facility provides a core nearly identical to the Advanced Test Reactor. This facility is housed in the Advanced Test Reactor building in an extended portion of the Advanced Test Reactor canal. The Advanced Test Reactor Critical Facility is used to obtain accurate and timely data on nuclear characteristics of the Advanced Test Reactor core to ensure safe, efficient, and reliable operation of the Advanced Test Reactor. 
Office of Nuclear Energy: Major Facilities

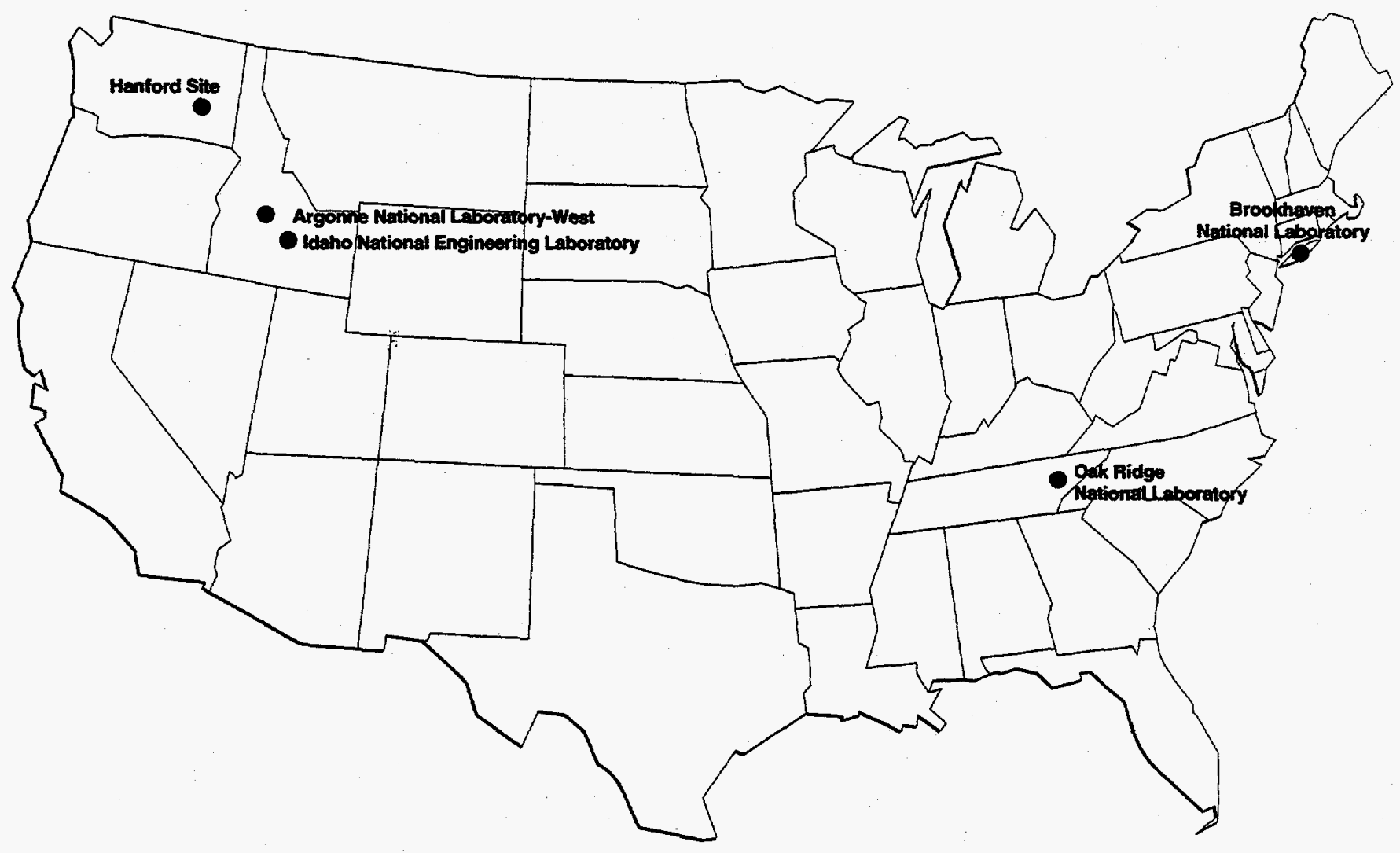

The Brookhaven Medical Research Reactor, operated in support of the Office of Energy Research, provides neutron beams for experimental research and boron neutron capture therapy, including human cancer treatment. In addition, the reactor provides irradiation facilities for neutron activation analysis and the generation of isotopes for experimental purposes.

At Argonne National Laboratory-West, the Neutron Radiography Reactor Facility was previously used to provide fast, high-quality neutron radiographs of fuels, materials, and components under examination at the Hot Fuels Examination Facility. Although it has no current mission, the Neutron Radiography Reactor Facility is being maintained operable for training purposes.

The Department is currently anticipating transferring the Annular Core Research Reactor in FY 1995 from the Office of Office of Defense Programs to the Office of Nuclear Energy for the production of isotopes. This Category B reactor will be considered a non-defense reactor once the transfer is made. Plans call for reactor startup and testing in early FY 1996, with molybdenum-99 production in mid-FY 1996. The Annular Core Research Reactor will also be able to produce other medical isotopes, such as iodine-125, iodine-131, and xenon-133. 


\section{Evolution of the Functional Mission}

In 1989, Secretary of Energy James Watkins assigned the Office of Nuclear Energy the responsibility for developing and coordinating departmental policy for all nuclear reactors. As part of this consolidation, the responsibility for the design, construction, and operation of the nuclear reactors under the cognizance of the Office of Energy Research was transferred to the Office of Nuclear Energy.

The Department's decision to move away from liquid metal reactor technology development in light of worldwide non-proliferation concerns has resulted in the decisions to shut down the Department's two liquid metal-cooled reactors, the Experimental Breeder Reactor-II and the Fast Flux Test Facility.

The end of the Cold War has resulted in a reduction in the Naval Reactors test program, thus making the use of the Advanced Test Reactor available for other sponsors. A major Department initiative has been to develop the potential of the Advanced Test Reactor as a national asset for both national and international science and industry.

\section{Future of Major Facilities}

The missions being fulfilled by the Department's operating non-defense reactors are expected to continue well into the next century.

The High Flux Isotope Reactor and the Advanced Test Reactor can be used to conduct irradiation testing required for the International Thermonuclear Experimental Research fusion reactor program. The High Flux Isotope Reactor is also being considered as a potential domestic source for the production of plutonium-238 to support space and defense missions. The Advanced Test Reactor has additional capabilities that the Department can take advantage of in meeting potential future needs including:

- conduct of irradiation experiments for other Department programs;

- $\quad$ production of additional isotopes for research, medical, and industrial purposes, and

- backup for High Flux Isotope Reactor for production of plutonium-238 if a decision is made to pursue a domestic option to supply this isotope for space and defense missions.

The Advanced Test Reactor Critical Facility is planned to operate as long as needed in support of Advanced Test Reactor operations.

Plans are to continue the operation of the Brookhaven Medical Research Reactor to perform short term research relating to treating cancer in humans. Once this research has been completed, the facility will be shut down. 


\section{ENERGY RESEARCH}

Three organizations have management responsibilities for conducting all basic and applied research in energy-related subject areas: the Offices of Energy Research, Energy Efficiency and Renewable Energy, and Fossil Energy. The Office of Energy Research conducts most of the basic energy-related research with programs in high-energy physics, nuclear physics, basic energy sciences, biological and environmental research, and fusion energy. Energy Research also supports energy-related university and science education programs nationwide.

\section{Functional Missions of Energy Organizations}

\section{Office of Fossil Energy}

The mission of the Office of Fossil Energy includes the management of fossil fuels research and development programs (i.e., coal, oil, natural gas); the Great Plains Gasification Plant Loan Guarantee Program; the Clean Coal Technology Program; the Geoscience Research Program; the Strategic Petroleum Reserve; the Naval Petroleum Reserve; the Naval Petroleum Oil Shale Reserves; and the Liquefied Gaseous Fuels Spill Test Facility.

Radioactive substances employed in fossil energy work are limited to the use of a few sealed radioactive sources used as test instrument check and calibration devices, and as biological and chemical process labeling devices. These types of sources are commonly used in many academic, commercial, and industrial research applications outside the Department.

\section{Office of Energy Efficiency and Renewable Energy}

The mission of this Department organization is to promote the adoption of cost-effective, renewable energy and energy efficiency technologies and practices together with the States and with partners in the private building, industrial, transportation, and utility sectors for the benefit of the economic competitiveness, energy security, and environmental quality of the Nation.

The radioactive substances employed in energy efficiency and renewable energy work are limited to the use of a few sealed sources to label biological and chemical processes. These types of sources are commonly used in many academic, commercial, and industrial research applications outside the Department.

\section{Office of Energy Research}

The Office of Energy Research has responsibility for the oversight of some of the Department's national laboratory complex consisting of 5 major multi-program laboratories and about 10 single program-dedicated laboratories. Two laboratories, one multiprogram and one single-purpose laboratory, are collocated with universities (Lawrence Berkeley Laboratory at the University of California and Ames Laboratory at Iowa State University.) 
The research conducted by the laboratories is funded by all of the Department's major program offices, other Federal agencies, and the private sector. Energy Research is also responsible for the operation of large accelerator facilities at these laboratories, which are essential tools of energy-related research. These facilities are made available to all of the Nation's scientists based on scientific merit and technical feasibility of proposed research.

High Energy Physics: The High Energy Physics Program is focused on obtaining an understanding of the ultimate structure of all matter and energy through the study of properties of elementary particles.

Nuclear Physics Program: The Nuclear Physics Program conducts a fundamental program of experimental and theoretical investigations of atomic nuclei and nuclear matter. These facilities are used to conduct research into medium energy, heavy ion, and low energy nuclear physics and nuclear theory.

Basic Energy Sciences: The Basic Energy Sciences Program supports long-range basic energy-related research and provides a fundamental scientific foundation for the Nation's future energy options. Basic Energy Sciences is organized to manage research in five areas including materials sciences, chemical sciences, engineering and geosciences, advanced energy projects, applied mathematical sciences, and energy biosciences. Most scientists involved in Basic Energy Sciences research are located at universities and national laboratories. In addition, qualified scientists from universities and industry are provided access to user facilities at the national laboratories.

Biological and Environmental Research: The Biological and Environmental Research Program has two main missions: (1) to develop the knowledge base necessary to identify, understand, and anticipate the longterm health and environmental consequences of energy use; and (2) to use the Department's unique scientific and technological capabilities to solve major scientific problems in medicine, biology, and environmental science. These missions reflect a commitment to develop beneficial uses of advanced energy technologies while assuring that any potentially adverse health and environmental impacts of the Nation's energy policies are fully understood. This program is increasingly oriented toward taking advantage of the promises emerging from biotechnology and its related scientific disciplines to achieve long-term program goals. The emphasis of the program is long-term research in health effects (radiation biology and chemical toxicology) and life sciences (cellular and molecular biology, including the Human Genome Project); medical applications and biophysical research, including analytical technology, radiological and chemical physics, and life sciences instrumentation; and environmental sciences including atmospheric science, terrestrial ecology, subsurface geological science, ocean margins, environmental radon, and global change.

Fusion Energy: Magnetic fusion is a potential long-term energy option that could become a principal energy source in the next century while using a vast, inexpensive fuel source and offering benefits in environmental and safety assurances. Magnetic fusion development also drives technology advances in fields as diverse as plasma physics, superconducting magnets, high-power accelerators and radiofrequency systems, mathematical methods of computing, and advanced materials development while providing a model for international collaboration. U.S. Fusion Policy has been to proceed with a goal-oriented program for the development of fusion energy directed toward operating a demonstration power plant by the year 2025 and a commercial power plant by the year 2040. Cost efficiencies have been realized through the collaborative work between U.S. and other fusion programs around the world as scientific and technological 
exchanges, joint experiments, and joint planning activities; and through the development of a unique, largescale International Thermonuclear Experimental Reactor.

University and Science Education: The University and Science Education Program provides the budgetary and programmatic focus for specialized research and science education efforts to ensure a steady flow of well-educated, highly skilled scientific personnel to carry out the Department's basic research and development and operational missions as well as contribute to the national effort to improve mathematics and science education at all levels.

\section{Major Facilities - Historical Perspective}

Department facilities involved in basic energy research are grouped into the following general categories: accelerators (particle and high energy light sources), and specialized research laboratories as found in universities performing analytical, physics, material science, biological science, and geosciences research. Most of these facilities are located at five large multiprogram, multipurpose research laboratories such as Oak Ridge National Laboratory and Brookhaven National Laboratory. In addition, basic energy research activities are conducted at other large defense-related laboratories at selected facilities, some with joint occupancy with other Department of Energy program offices (i.e., the Offices of Defense Programs and Environmental Management) and at single-purpose, dedicated laboratories such as Ames Laboratory (material sciences) and Princeton Plasma Physics Laboratory (magnetic fusion).

High Energy Physics Program activities are conducted primarily at large experimental laboratories like the Fermi National Accelerator Laboratory and the Stanford Linear Accelerator Center. Researchers in the Nuclear Physics Program use accelerator facilities including the Clinton P. Anderson Los Alamos Meson Physics Facility at the Los Alamos National Laboratory and a variety of facilities at locations such as the Lawrence Berkeley Laboratory and Argonne National Laboratory. At these research sites, the Office of Energy Research manages or sponsors work in a total of 12 large accelerators and 23 nuclear facilities, and performs a landlord function at the 5 multipurpose research laboratories. These facilities are illustrated in Figure 3.

The Offices of Fossil Energy and Energy Efficiency and Renewable Energy currently operate no nuclear or radiological facilities or operations.

\section{Current Status}

Energy Research nuclear (see Appendix B) and radiological (see Appendix C) facilities include no Category 1 (high hazard), 4 Category 2 (moderate hazard), and 19 Category 3 (low hazard) nuclear facilities and various radiological facilities, including 13 accelerator facilities. Generally, the hazards present in these facilities are of the type normally present in many government, academic, and private-sector research environments. Energy Research has two accelerator facilities under construction, as well as a new environmental and molecular science research laboratory. New research facilities have been proposed for fusion and neutron beam research, the latter using an accelerator as a source. Many of these facilities are "user facilities," in that visiting scientists and students have access to conduct compatible research. The Department also owns buildings at three other university sites in which energy research is conducted, and "work for others" is conducted at some of the Energy Research facilities, particularly at the multipurpose laboratories. 
One accelerator is questionable for longer term research, and the Tokamak Fusion Test Reactor is to undergo decontamination for conversion of the facility to a new experiment, the Tokamak Project Experiment. In addition, Energy Research is a cosponsor of the International Thermonuclear Experimental Reactor for which the international location is yet to be determined. This experimental reactor will be constructed in the next decade.

\section{Evolution of the Mission}

No major redirection of the mission is anticipated. Normal evolution of the energy research mission is currently governed by progress and findings that emerge from the above-described program areas and research findings by other organizations external to the Department.

\section{Future of Major Facilities}

Several new accelerator and laboratory facilities are planned in the near future. These facilities include:

- the Relativistic Heavy Ion Collider at Brookhaven National Laboratory,

- the Advanced Photon Source to be used in Basic Energy Sciences Programs at Argonne National Laboratory, and

- the Environmental and Molecular Science Laboratory at Pacific Northwest Laboratory.

In addition, it is anticipated that accelerator and other facilities will be upgraded over time to facilitate more advanced and different research into energy-related sciences and technologies. None of these facility upgrades are anticipated to result in significant radioactive material hazards. 
Office of Energy Research: Major Facilities

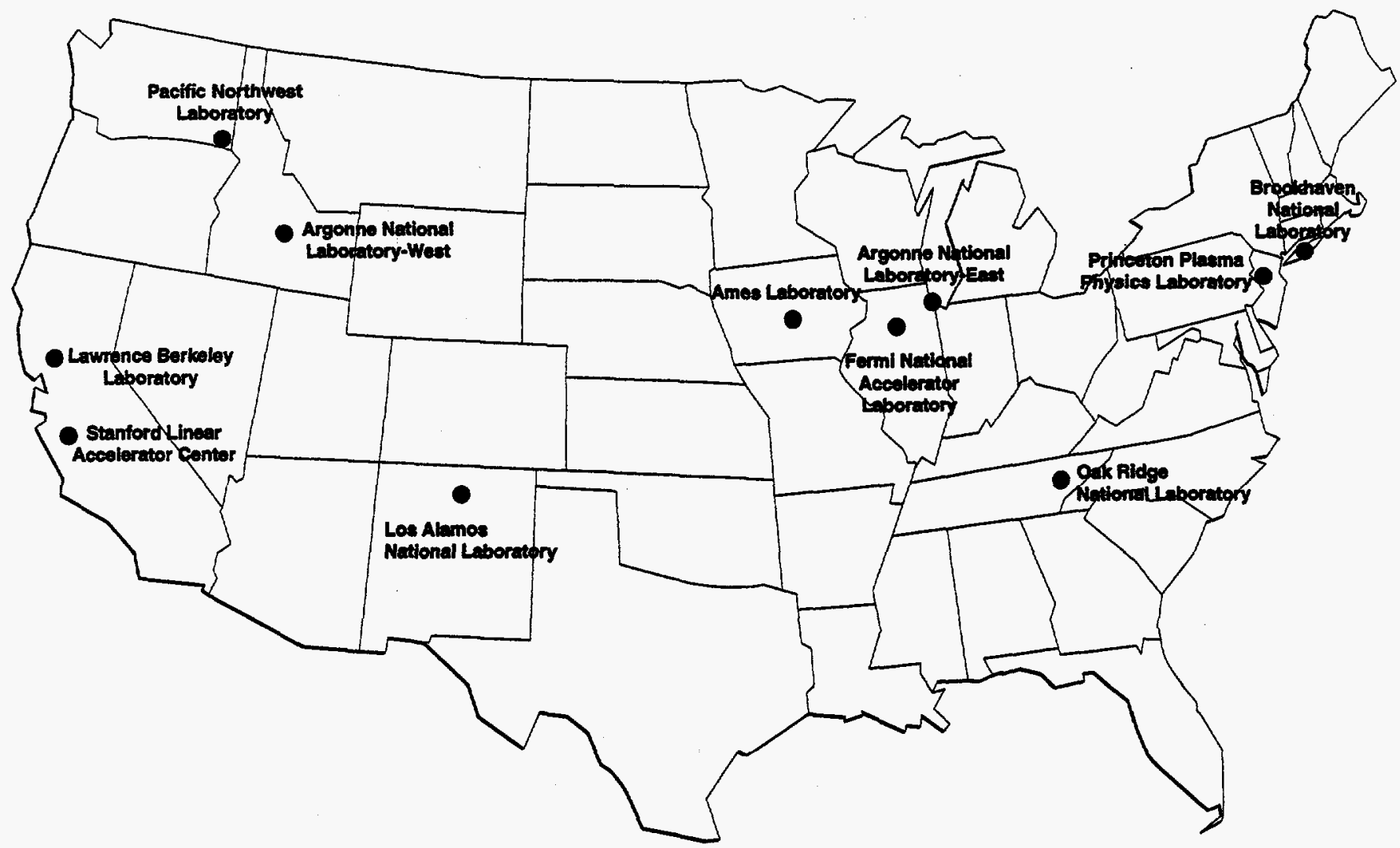





\section{WASTE MANAGEMENT}

\section{Functional Mission}

The Department of Energy's Waste Management program oversees the national program to protect people and the environment from the hazards of waste that resulted from the Nation's nuclear weapons program and other Department operations. Nuclear materials production for nuclear weapons resulted in a variety of waste streams from several steps in the process. Mining and milling uranium has left huge volumes of mill tailings. These tailings pose a risk due to the potential exposure to uranium that may enter ground or surface water by runoff, as well as a radioactive hazard from the creation of radon from the tails.

The program deals with four waste types beside mill tailings: low-level, high-level, mixed (radioactive and hazardous), and transuranic waste (detailed definitions of these waste types are provided in Chapter VII). Uranium enrichment processes resulted in low-level and mixed wastes, as did reactor fuel and target fabrication; reactor operations created low-level, high-level and mixed waste; chemical separation or "reprocessing" activities resulted in large volumes of high-level waste (highly radioactive waste resulting from dissolving spent nuclear fuel in nitric acid solution) and other forms; weapons component fabrication produced transuranic, low-level, and mixed waste; and research, development, and testing activities resulted in all four types of waste. The program also oversees the safe storage and disposition of waste resulting from other DOE activities, such as nuclear energy research, isotope production, and other programs.

The core elements of the Waste Management mission are to:

- $\quad$ ensure safe storage of waste;

- reduce Environment, Safety and Health near-term risks through treatment and packaging of waste; and

- minimize long-term risks and costs through disposal.

The mission of the Office of Civilian Radioactive Waste Management is to manage and dispose of the Nation's spent nuclear fuel and high-level radioactive waste.

\section{Major Facilities - Historical Perspective}

Waste management programs are located in 22 States. Facilities for at least some level of treatment, storage, or disposal of radioactive waste exist or will be constructed in each of these States.

\section{Treatment}

Treatment facilities process waste to reduce the volume or toxicity of radioactive and hazardous chemical material and make it safer to handle. Selection of the treatment methods depends on the quantity and form of the waste material. Chemical processing plants take liquid waste or sludge and convert it to a waste form suitable for permanent disposal. Liquid waste can be solidified by spraying droplets onto hot particles and 
removing moisture (calcining). Sludge can be immobilized by mixing it with molten glass (vitrification). Vitrification facilities exist or are being built at the Savannah River Site, the Hanford Site, and at the West Valley Demonstration Project

Mixed waste will be treated with technologies that meet the requirements of the Resource Conservation and Recovery Act regulated components of these wastes. Any further treatment will be applied as is appropriate for the respective radioactive component of the waste (i.e., low-level, transuranic, high-level). Treatment for low-level and transuranic wastes will be focused on meeting the waste acceptance criteria for the receiving disposal site (e.g., the Waste Isolation Pilot Plant for transuranic waste).

\section{Storage}

Waste storage is an interim solution. High-level waste is stored in tanks encased in concrete with capacities from 500,000 to 1,000,000 gallons at the Hanford Site in Washington and the Savannah River Site in South Carolina. Transuranic waste is placed in drums and stacked on asphalt or concrete pads. Mixed waste is stored in various container configurations pending treatment and disposal. Most storage does not comply with regulatory requirements that restrict the amount of time untreated waste may be stored.

\section{Disposal}

The Department intends to send solidified high-level radioactive waste to a planned Federal geologic repository. A geologic repository is required for deep geologic disposal of spent nuclear fuel and high-level radioactive waste. Yucca Mountain in Nevada is presently the only site being studied as a potential repository. The need for a second repository will be assessed in the 2007-2010 time frame.

Most low-level waste is disposed of in shallow land burial trenches and aboveground bunkers. Defensegenerated transuranic waste is planned to be disposed of at the Waste Isolation Pilot Plant in New Mexico.

The Office of Civilian Radioactive Waste Management is developing a system to accept, transport, store, and permanently dispose of spent nuclear fuel and high-level radioactive waste from commercial utilities. The system would also provide for the disposal of defense-related high-level waste.

An interim storage facility for monitored retrievable storage of commercial spent nuclear fuel would help relieve storage problems at utilities. The Office of Civilian Radioactive Waste Management's early efforts to site a storage facility have been curtailed, and the objective of accepting spent nuclear fuel by 1998 appears doubtful. The Office of Civilian Radioactive Waste Management is currently reviewing options for waste acceptance and storage with its stakeholders.

\section{Current Status}

\section{Storage Facilities}

Storage facilities exist, are under construction, or are planned for virtually all of the Department's 41 field sites generating radioactive and/or mixed waste. 
In collaboration with Congress and stakeholders during 1995, the Office of Civilian Radioactive Waste Management will be clarifying its role in building and operating a storage facility. The Office of Civilian Radioactive Waste Management does not currently possess radioactive materials.

\section{Treatment and Disposal Facilities}

Facilities for the treatment of high-level waste are in various stages of completion. The Defense Waste Processing Facility has conducted test runs and awaits final operational startup. Vitrification units at the Hanford Site and the West Valley Demonstration Project are under design and construction. The Secretary of Energy will determine whether the Yucca Mountain site is suitable for development as a repository in 2000. If suitable, the Secretary intends to submit an application in 2001 to the Nuclear Regulatory Commission for authorization to construct the repository. A license application to receive and emplace/dispose high-level waste in the repository would be submitted in 2008 .

For the treatment of transuranic waste, existing facilities consist primarily of size-reduction and compaction processes. Future treatment of transuranic waste will be dictated primarily by the final waste acceptance criteria for the Waste Isolation Pilot Plant. The Waste Isolation Pilot Plant site is the only site undergoing study and tests to decide its suitability for accepting transuranic waste for disposal.

For low-level waste, treatment facilities that consist primarily of size reduction and compaction are in operation at most sites generating low-level waste. Only one Department of Energy facility, located at the Savannah River Site, has demonstrated compliance with Department requirements for low-level waste disposal. Commercial disposal facilities now represent a diminishing disposal option. The Barnwell, South Carolina, site discontinued receipt of out-of-region waste in June 1994 and is expected to receive only Southeast Compact waste until the end of 1995. The only other operating low-level disposal site, which is located at Richland, Washington, has restricted access only to members of the Northwest and Rocky Mountain Compacts in late 1992. While new regional facilities are planned, none are expected to be operational in the near future.

For the treatment of mixed waste, the only currently operating facility is the Toxic Substances Control Act incinerator at Oak Ridge, Tennessee. This facility treats wastes containing radioactive materials mixed with polychlorinated biphenyl compounds. Some small amounts of mixed waste have been sent to commercial treatment facilities (e.g., SEG Corporation and Envirocare, Inc.). A large number of treatment facilities, and disposal options, are being evaluated and are in the very early planning stages in response to the Federal Facility Compliance Act.

\section{Evolution of the Mission}

With the end of the Cold War, the Department of Energy is facing decisions concerning the disposition of plutonium, highly enriched uranium, and other radioactive materials that will be recovered in defense complex cleanup efforts. The decontamination and decommissioning of facilities is expected to consolidate currently dispersed quantities of plutonium and highly enriched uranium, thus adding to the inventory of transuranic waste. 
Currently, the various processes used for nuclear weapons production are shutdown except for those supporting the weapons dismantlement and stockpile stewardship missions. However, the waste management program will undertake increasing responsibilities as facilities are transitioned from former missions, deactivated, decontaminated, and, in some cases, demolished. These activities will continue to produce waste streams; in fact, the volume of waste created by environmental restoration activities will exceed the amount of waste currently managed by the program. Future missions and the evolution of current missions at the various Department national laboratories are expected to influence waste management practices. As the primary missions shift from defense-related research to non-defense research such as industrial technology, medicine, etc, the makeup of the radioactive waste generated will change.

\section{Future of Major Facilities}

The expected future for waste management facilities has been discussed earlier. In summary, these facilities will focus on the following objectives:

- Treat, store, and dispose of the waste legacy from the nuclear weapons production (20-30 years); and

- Continue to provide waste management services for DOE programs (20-30 years).

For high-level waste, the geologic repository would be operated to allow waste retrieval, if needed, for up to 100 years from the start of waste emplacement. When the acceptable performance of the repository is confirmed, the Department would apply to the Nuclear Regulatory Commission to close the repository. An interim storage facility could be licensed for a period of up to 40 years, and this license is renewable. Before the license terminates, the facility would be decommissioned. 


\section{ENVIRONMENTAL RESTORATION}

The Office of Environmental Management is responsible for the administration of research and development, technology demonstration and transfer, and site remediation process efforts for all sites owned and/or operated by the Department of Energy.

\section{Functional Mission}

The Department's Environmental Restoration program directs the assessment and cleanup of its sites and facilities contaminated with waste from defense-related activities. Environmental Restoration's mission is to protect human health and the environment by addressing contaminated soil, ground water, surface water, structures, and other materials at Environmental Management sites and facilities in the nuclear weapons complex.

The Environmental Restoration program cleans up radioactive waste, hazardous waste, mixed waste, and other contamination at Department of Energy sites. Environmental restoration activities include remedial actions (the assessment and cleanup of inactive waste sites) and decontamination and decommissioning (the cleanup and demolition or reuse of surplus facilities). Some areas at these sites and facilities have been contaminated by unwanted releases or spills into the environment, or by past practices believed safe and adequate at the time. Today's standards for protecting human health and the environment are more stringent, and some old sites must be cleaned up again to meet these standards. Some facilities that were used to produce nuclear materials are no longer needed, and these facilities will be cleaned up and either demolished or reused for nonnuclear purposes.

\section{Major Facilities - Historical Perspective}

The Department is currently responsible for over 130 sites in 33 States and 1 territory (Puerto Rico). The number of Department of Energy sites changes as new sites are identified or transferred by Congress to the Office of Environmental Management, or as it is decided that the Department has no responsibility for a particular site. The Office of Environmental Restoration does not manage these sites independently since regulatory agencies verify compliance, and more than 70 percent of the Environmental Restoration program is tied to regulatory commitments. Examples of types of Department sites and facilities include nuclear reactors, laboratories, landfills, burial grounds, waste ponds, seepage pits/cribs, surface spills, and buried debris. These sites are illustrated in Figure 4.

\section{Current Status}

The Environmental Restoration program is managed as 17 primary projects throughout the country, subdivided into smaller projects. These 850 projects include 320 at National Priorities List sites; 80 other Comprehensive Environmental Response, Compensation, and Liability Act activities, commonly called Superfund projects; 97 Resource Conservation and Recovery Act closures; 108 Resource Conservation and Recovery Act corrective actions; 156 decontamination and decommissioning projects; 24 Uranium Mill Tailings Remedial Action Project sites; and 46 Formerly Utilized Sites Remedial Action Program sites. Other responsibilities include landlord, oversight, surveillance and maintenance, and technical assistance 
Office of Environmental Restoration: Major Facilities

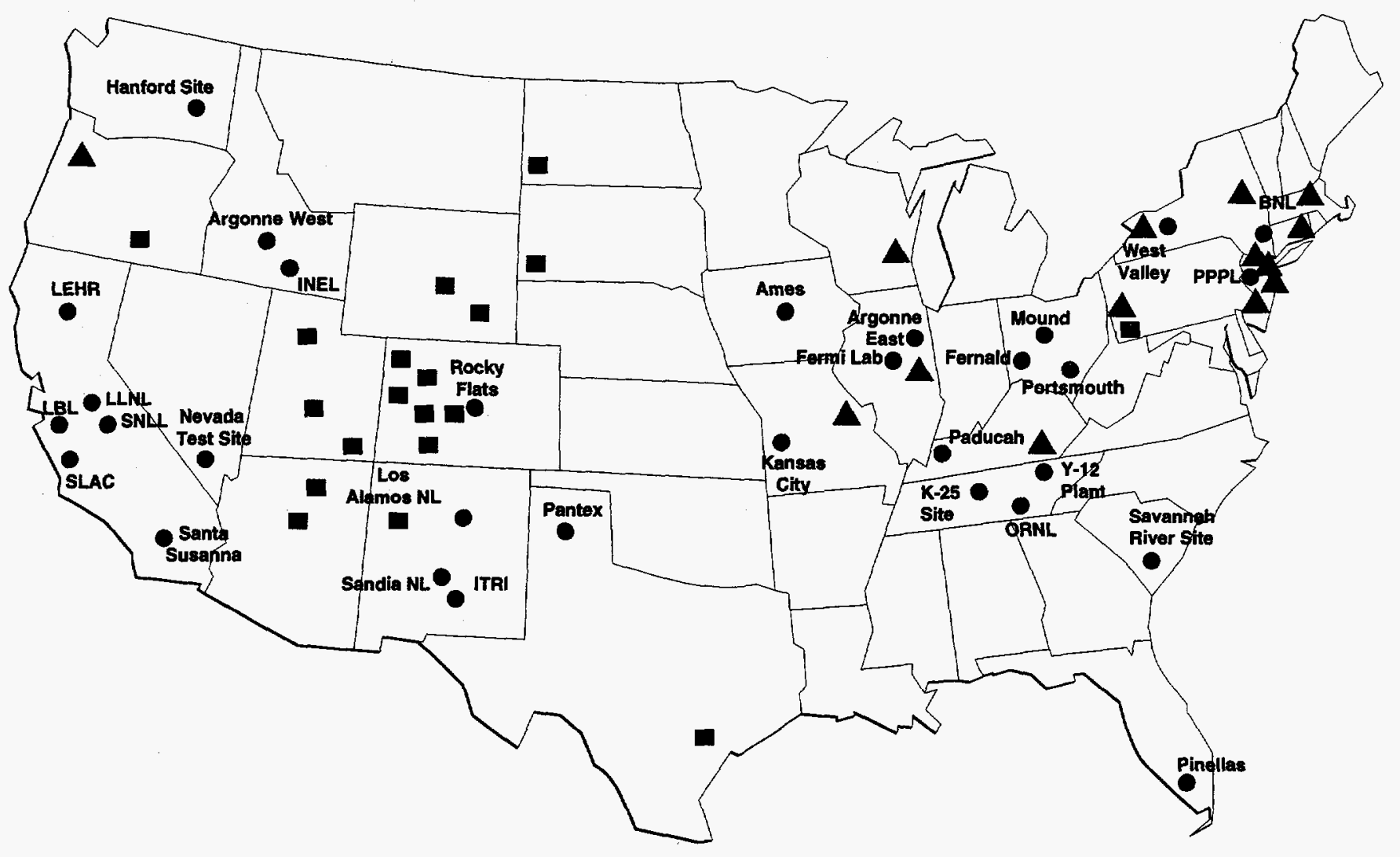

Facilltie
A FUSRAP
a UMTRA

Abbreviations:

BNL Brookhaven National Laboratory

ORNL

ITRI Inhalation Toxicology Research Institute

ORNL Oak Ridge National Laboratory

Laboratory for Energy-Related Research SLAC

LLNL Lawrence Livermore Mational Laboratory SNL-L

Princeton Plasma Physics Laboratory

Stanford Linear Accelerator Center Lawrence Berkeley Laboratory

Sandia National Laboratory-Livermore

to support primary remediation work. As of September 30, 1994, 114 remedial actions and decontamination and decommissioning projects (not including Formerly Utilized Sites Remedial Action Program or Uranium Mill Tailings Remedial Action Project) have been completed.

For each project, the Department characterizes the problems to determine an appropriate course of action. Regulators and other stakeholders are involved in this process at all levels, including direct oversight as members of advisory boards and through public meetings. The characterization process includes sampling and analysis, modeling, evaluation of historical records, and studies of appropriate remedial alternatives. When site characterization is complete, the Department, with regulators and stakeholders, determines the appropriate remediation strategy, selects a final remedial alternative, and begins remediation.

At all sites where environmental management activities are conducted, interim actions are used to address urgent risks and remove potential threats before the completion of detailed characterization studies. Interim 
actions include expedited response actions, removal actions, and actions to stabilize and contain waste or offsite plume migration. In 1994, the program completed 11 of the interim actions. In 1995, the Department intends to complete another 8 interim actions, bringing the total to more than 180 since the program was established.

In 1994, some sites crossed an important marker in the program by spending more funds on actual remediation than assessment. This trend will continue in future budget planning with even more funds devoted to remediation. This measurable success has been made in large part due to the implementation of the Federal Facility Agreement and Consent Order.

The following are examples of types of facilities and the amount and form of radioactive/hazardous material that is present:

- $\quad$ Pit 9 at the Idaho National Engineering Laboratory is an inactive disposal pit approximately 1 acre in size. Pit 9 houses 150,000 cubic feet of low-level waste in several large reactor vessels.

-

At the sites under the Oak Ridge Operations Office in 1994, 125 million gallons of wastewater were treated and 1.1 million cubic feet of sanitary waste were disposed. At the Oak Ridge National Laboratory in 1994, 50,000 gallons of radioactive liquid waste were solidified and prepared for shipment, and the Toxic Substances Control Act incinerator burned 5.6 million pounds of mixed waste liquids.

\section{Evolution of the Mission}

During World War II, nuclear materials production facilities were built at locations across the country for security reasons. Related activities were conducted at universities and industry locations where facilities already existed. The Department is responsible for cleaning up contamination from activities at all these locations.

The Environmental Restoration program will continue to grow as more facilities are transferred to the Office of Environmental Management. Recently, the Office of Environmental Management assumed full "ownership" of three new sites: Mound in Ohio, Pinellas in Florida, and the vast Savannah River Site in South Carolina. Nearly 2,400 new facilities have been added to the Environmental Restoration program's responsibility, bringing the total to over 7,100 facilities. Decontamination and decommissioning of many of these facilities is a key activity, and the program plans to complete 12 decontamination and decommissioning projects in FY 1996.

\section{Future of Major Facilities}

With the Department's changing mission needs, the future uses of existing buildings and areas of land are likely to change. In some cases, land and buildings will be retained by the Department to support mission needs. In other instances, land and facilities may be transferred or leased for other governmental or private sector uses. 
The Department has an ongoing site development planning process for deciding general uses of its land and buildings. This process includes a framework for identifying a range of stakeholder-preferred future- use options that includes the following elements: establishing Departmental roles, responsibilities, and commitment to identifying future-use options at the site; designing a process, in consultation with stakeholders, that will identify future use options; providing stakeholders meaningful participation in the process; providing relevant information about sites and facilities to stakeholders; and evaluating opportunities, constraints (particularly those that are technical and legal in nature), and Department and stakeholder needs. While the Department cannot delegate its stewardship responsibilities and authorities for final decisions regarding future uses at its sites, stakeholders are being included in the decision making process to ensure that sound decisions which are acceptable to stakeholders are made. 


\section{TRANSITION}

\section{Functional Mission}

The Office of Nuclear Material and Facility Stabilization (EM-60, formerly the Office of Facility Transition and Management) was established in July 1992 within the Office of Environmental Management. The mission of this office is to coordinate and oversee the orderly transition of contaminated facilities from other program offices to Environmental Management, once these properties were determined to be surplus to their mission.

The Office of Nuclear Material and Facility Stabilization protects workers, the public, and the environment from exposure and contamination associated with radioactive and hazardous wastes and materials contained within the surplus facilities. The majority of these facilities were former weapons production facilities and not designed for long-term storage. Many of these facilities and hazardous materials are expensive and labor intensive. An active program has been established for surplus facilities to identify, plan, and accomplish projects that will properly stabilize and store the materials, thereby reducing the funding requirements.

All maintenance and stabilization activities are conducted with full participation of involved stakeholders. The interests of stakeholder groups encompass environmental protection, individual safety, and proper management of surplus facilities located close to large metropolitan areas.

Additionally, the Office of Nuclear Material and Facility Stabilization is assigned landlord responsibility for selected facilities to ensure utilities and support services are maintained at an adequate level to support the environmental remediation and material stabilization activities at the site. Landlord activities typically include site infrastructure needs (i.e., roads, sewer systems, security, electrical distribution systems, communications, etc.) as well as the provision of medical, emergency, and cafeteria services.

The Office of Nuclear Material and Facility Stabilization is also actively involved in transitioning the workforce in both size and technical capability from the requirements to support the operational weapons product mission to the requirements to support deactivation and stabilization.

\section{Major Facilities}

The Office of Nuclear Material and Facility Stabilization currently has landlord responsibilities at the Hanford, Idaho National Engineering Laboratory, Rocky Flats, and Savannah River sites. Nuclear materials stabilization is concentrated at Rocky Flats, the Hanford Site's Plutonium Finishing Plant, and the F- and H- Canyons at the Savannah River Site. In addition to these sites, the Office of Nuclear Material and Facility Stabilization is preparing to accept the transfer of the Mound and Pinellas plants.

Deactivation of the PUREX and Plutonium Finishing plants at Hanford and the Idaho Chemical Processing Plant is well underway. Deactivation of the Fast Flux Test Facility will begin in FY 1995; deactivation of $\mathrm{UO}_{3}$ is complete. The processing of solutions at F-Canyon has begun. 


\section{Current Status}

Major nuclear stabilization efforts are being undertaken in response to the problems identified by the Defense Nuclear Facilities Safety Board's Recommendation 94-1 and the Department's Plutonium Vulnerability Assessment. Current work in this area includes the solidification of liquid solutions, venting of plutonium residue drums, and repackaging of metals and oxides at Rocky Flats and the Plutonium Finishing Plant, and the start of F-Canyon at the Savannah River Site to stabilize the plutonium solutions.

\section{Evolution of the Functional Mission}

The Department of Energy has declared many of the facilities formerly used in the production of nuclear weapons and nuclear research surplus to current defense and other Department programmatic needs. Many of these facilities are contaminated with nuclear and chemical hazards; therefore, they require a significant amount of surveillance and maintenance to adequately protect our workers and the environment from the existing hazards. Because this activity differs from the former production mission, the management of these facilities is transferred to the Assistant Secretary for Environmental Management after the facility is declared surplus.

The Office of Nuclear Material and Facility Stabilization has developed and implemented a process for transitioning surplus facilities to the Office of Environmental Management for final disposition. The office currently is responsible for maintaining the integrity of facilities and stabilizing nuclear materials to ensure the safety of workers and the public.

\section{Future of Major Facilities}

It is not possible to immediately or simultaneously shutdown, or decommission, all of the approximately 21,000 surplus facilities the Department manages due to the tremendous financial resources needed, health and safety considerations involved, and the economic impact on the surrounding communities. However, the Department has developed a strategy to deactivate facilities on a priority basis to ensure that as many as possible are placed in a safe, stable, and economical condition so that they can be monitored and maintained from an extended period while awaiting final decommissioning. The Department then applies its resources to accomplish the most, in terms of facility safety, in the shortest amount of time. 


\section{NUCLEAR MATERIAL MANAGEMENT}

The Department of Energy directs the safe management and disposition of a wide range of nuclear materials and the treatment, storage, and disposal of radioactive waste generated by the Department's nuclear-related activities. The activities that generate or utilize these materials include weapons production and dismantlement, defense materials processing, manufacturing, reactor operation, research and development, and site cleanup activities. The discussion in this chapter is not intended to be all inclusive. This chapter is designed to provide a representative picture of the types, amounts, and forms of nuclear material managed by the Department. The Office of Policy, Planning and Program Evaluation is current developing a nationwide baseline report on the facilities and materials under the auspices of the Department. This Baseline Material Inventory Report will discuss nuclear materials in detail and is expected to be completed within the next few months.

\section{Nuclear Materials}

These materials consist of a sizeable inventory of various fissile isotopes and non-fissile materials. The total inventory is about 433 metric tons, not including classified inventories. The primary fissile materials include plutonium, uranium, and thorium, which are used in or resulted from nuclear weapons production or fuel fabrication/reprocessing for production nuclear reactors. These nuclear materials are managed through the Nuclear Materials Management and Safeguards System, which tracks 17 different materials. Site operations focus on material processing, packaging, and storage activities for safeguards purposes.

The total amount of plutonium (estimated sum of unclassified weapons grade and reactor grade material inventories) is approximately 33 metric tons. The majority of this material ( 73 percent) is located at 2 sites, the Rocky Flats Environmental Technology Site in Colorado and the Hanford Site in Washington. The aggregate inventory of uranium (depleted, normal, and enriched) is in excess of 430,000 metric tons, with 98 percent of this inventory being depleted or normal uranium. The majority of the enriched/highly enriched uranium inventory of about 7,600 metric tons is located at 3 Department of Energy sites. These sites include the Hanford Site in Washington (50 percent of the inventory), the Fernald Environmental Management Project Site in Ohio (28 percent of the inventory), and the Paducah Gaseous Diffusion Plant in Kentucky (14 percent of the inventory). The thorium inventory is about 106 metric tons, with 83 percent of this inventory located at 3 Department of Energy sites: the Idaho Chemical Processing Plant located on the Idaho National Engineering Laboratory in Idaho, Sandia National Laboratory (Albuquerque) in New Mexico, and the Fernald Environmental Management Project Site in Ohio.

\section{Radioactive Waste and Spent Fuel}

Radioactive waste is managed from generation through treatment, storage, and disposal facilities and operations. Radioactive waste storage is viewed by the Department as an interim measure until disposal sites are available and acceptance criteria are met. In some cases, radioactive waste is stored prior to treatment or while awaiting the availability of better treatment facilities. After treatment, the Department will store the treated waste if necessary until a final disposal facility is developed, licensed, and approved. 
The Department manages radioactive waste according to waste type as defined by the scientific community and various regulations. Waste is characterized according to its toxicity and hazard, as well as its radioactive nature. For detailed definitions of the various waste forms, refer to the Office of Environmental Management's January 1995 publication, Closing the Circle on the Splitting of the Atom.

\section{High-Level Waste}

High-level waste is highly radioactive material generated in the reprocessing of spent nuclear fuel and irradiated targets for weapons-grade materials. High-level waste includes both liquid and solid wastes that must be handled remotely to protect workers, the public, and the environment. The majority of the current U.S. inventory of high-level waste is stored at the Savannah River Site in South Carolina, at the Idaho National Engineering laboratory in Idaho, and at the Hanford Site in Washington. This is referred to as Department of Energy generated high-level waste. A small amount of high-level waste was generated at the Nuclear Fuel Services Plant near West Valley, New York. This waste is referred as commercial highlevel waste and is being managed under the West Valley Demonstration Project. As of the end of 1992, the Department managed a total of 398,350 cubic meters of high-level waste. These are primarily acidic and alkaline wastes in the form of liquid, salt cake, slurry, and sludge.

\section{Figure 5. High-Level Waste (cublemeters)}

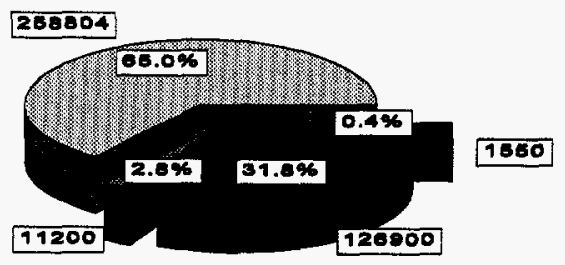

\section{Transuranic Waste}

Transuranic waste is defined as waste contaminated with radionuclides with half-lives greater than 20 years and concentrations of alpha-contaminants heavier than uranium (greater than $100 \mathrm{nCi} / \mathrm{g}$ ), particularly plutonium. Transuranic waste is generated by research and development activities, plutonium recovery, weapons manufacturing, environmental restoration, and decontamination and decommissioning activities. This waste is currently either disposed in shallow landfill-type enclosures (referred to as buried) or stored in earth-mound berms, concrete culverts, and aboveground buildings (referred to as retrievably stored). Transuranic waste is located at 18 sites. 
The majority of transuranic waste is in the form of solids such as rags, glass, protective clothing, tools and equipment that have become contaminated. Some transuranic waste is in the form of sludge from plutonium recovery chemical processing operations. These wastes vary widely in contamination level and are further classified as "contact handled" or "remote handled" depending on the radiation level at the surface of the waste package. About 10 percent of this waste is highly contaminated enough to be characterized as "remote handled" waste (radiation level greater than $200 \mathrm{mrem} / \mathrm{h}$ ).

A portion of the transuranic waste inventory consists of transuranic-mixed waste. This waste contains concentrations of both radioactive transuranic elements and chemically or physically hazardous chemicals. Current total transuranic/transuranic-mixed waste inventories are about 650,000 cubic meters, 90 percent of which is located at 3 Department sites: the Idaho National Engineering Laboratory, the Nevada Test Site, and the Hanford Site.
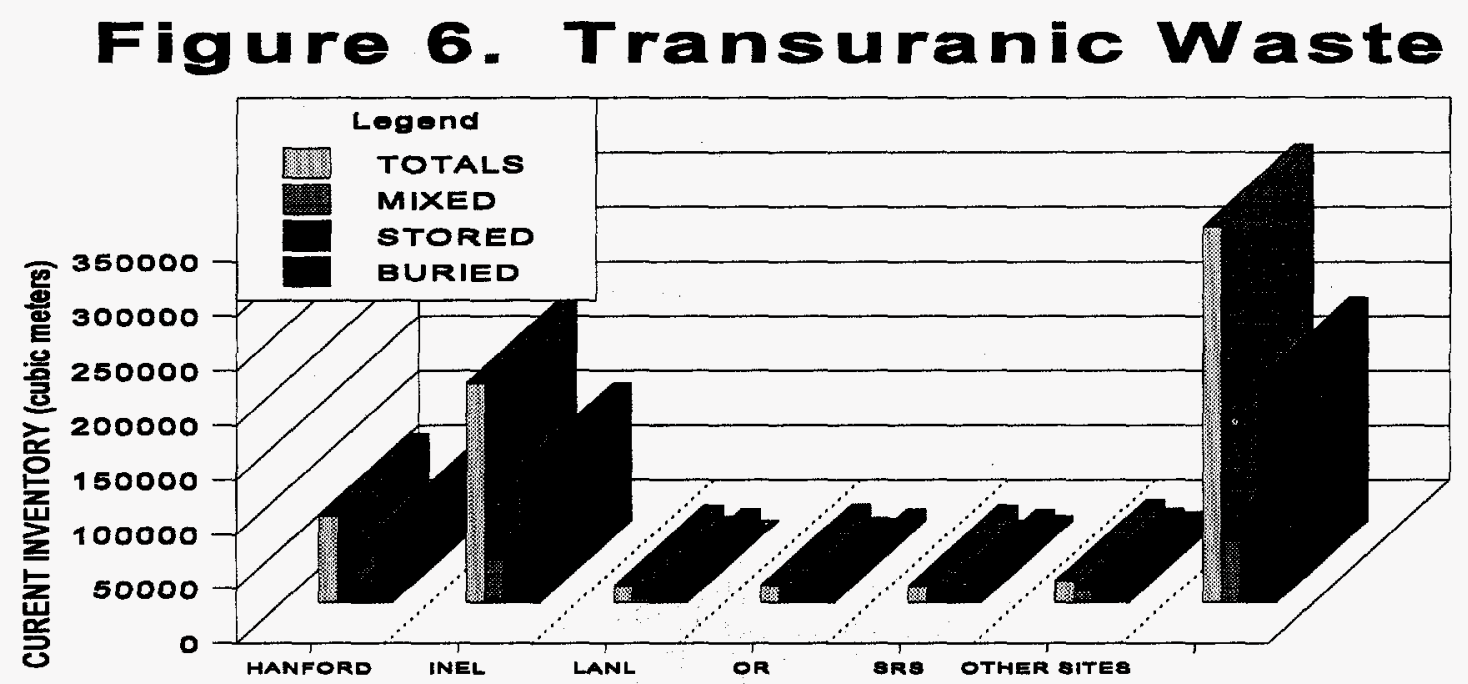

\section{Low-Level Waste}

Low-level waste is defined as radioactive waste that is not classified as high-level waste, spent nuclear fuel, or byproduct material specified as uranium or thorium tailings and waste. Low-level waste contains small amounts of radioactivity dispersed in large amounts of material such as contaminated equipment, clothing, solidified and non-solidified sludge, construction debris, etc. These wastes are generated by uranium enrichment processes, weapon manufacturing/assembly/disassembly, reactor operation, isotope production, naval nuclear propulsion program, radiological medicine, and research and development activities. Some low-level waste is also generated by decontamination and decommissioning, and environmental cleanup efforts. Currently, all Department of Energy generated low-level waste is buried at Department sites. Prior to 1979 , some Department of Energy generated low-level waste was shipped to commercial low-level disposal sites.

The inventories of low-level waste that the Department has or is expected to take possession of includes the following three important subgroups of waste: (1) low-level waste comprised of low-concentration radioactive-contaminated materials, (2) Greater-Than-Class-C low-level waste (generated from commercial 
sources), and (3) low-level/mixed waste. Low-level Greater-Than-Class-C waste is defined by the Nuclear Regulatory Commission in 10 CFR 61 as radioactive waste with concentrations of certain short- and longlived radionuclides not suitable for near-surface disposal. This waste, per Nuclear Regulatory Commission rules, is required to be disposed of in a deep geologic repository. This waste contains low, dispersed concentrations of both radioactive elements and chemically or physically hazardous chemicals.

Current total low-level waste inventories are about 265,639 cubic meters, 60 percent of which is located at 6 Department of Energy sites: the Savannah River Site, the Oak Ridge site, the Nevada Test Site, the Rocky Flats Environmental Technology Site, the Los Alamos National Laboratory, and the Hanford Site. The current inventory of Greater-than-Class-C waste is approximately 2054 cubic meters.

\section{Figure 7. Low-Level Waste}

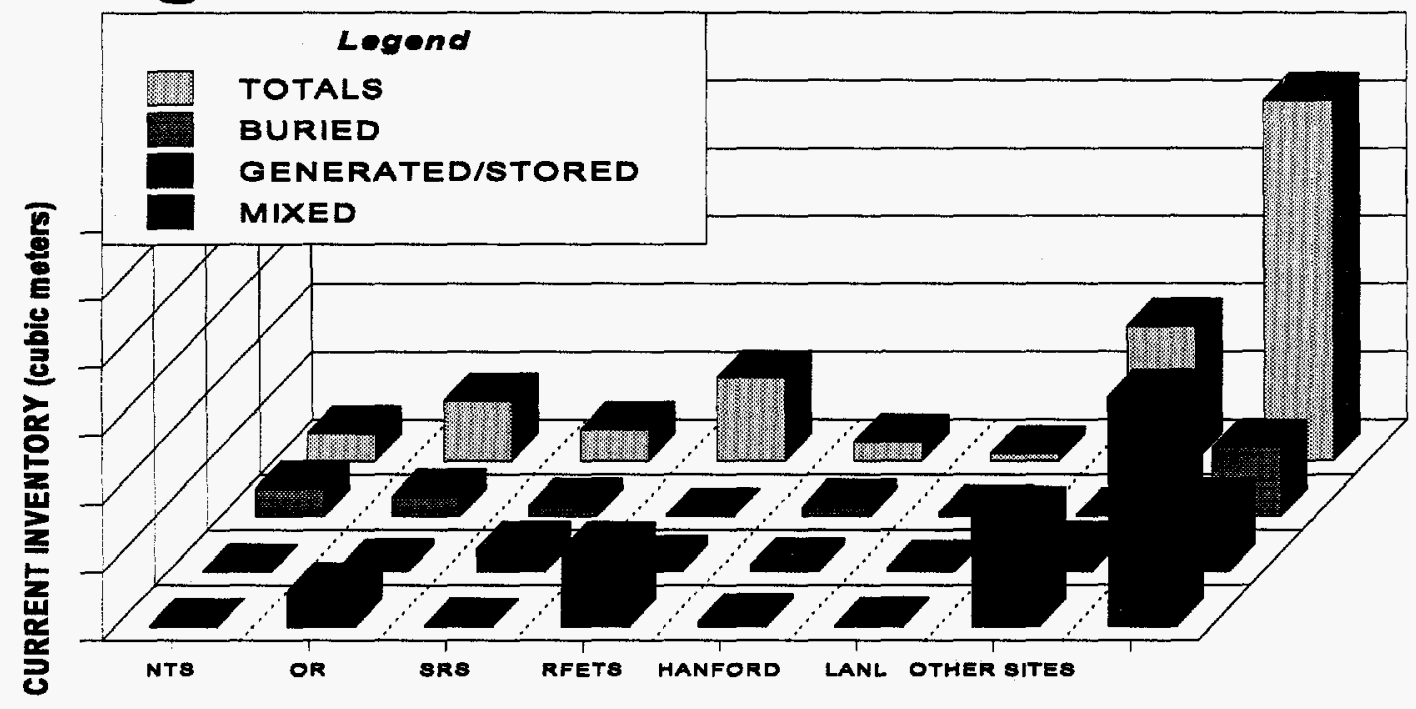

\section{Special Case Wastes}

Special case wastes include a wide variety of forms and isotropic mixes, located in various research laboratories, production buildings, and other facilities across the Department of Energy complex. The inventory consists of the following types of materials:

- $\quad$ Non-certifiable defense and non-defense transuranic wastes - defense-generated transuranic wastes that will not meet the acceptance criteria for the Waste Isolation Pilot Plant in their current form, or transuranic wastes generated from Office of Energy Research, Office of Nuclear Energy, or Nuclear Regulatory Commission licensee activities.

- Specific Performance Assessment Required and Performance Assessment Limiting wastes radioactive wastes that contain concentrations of radionuclides Greater-Than-Class-C limit in 
10 CFR 61.55 or low-level wastes with radionuclides in concentrations that exceed disposal site performance assessment limits.

Fuel and fuel debris - reactor fuel and fuel debris used in research and development efforts, similar to high-level waste. These wastes may not meet the disposal acceptance criteria.

- Uncharacterized wastes - radioactive wastes believed to contain nuclear materials at or near the limits of Specific Performance Assessment Required or transuranic wastes. These wastes require form, activity, and hazardous/toxic material characterization.

- Sealed sources - encapsulated radioactive materials used for those instances when a known amount of radiation is need for an activity. These materials are excess to program needs and due to their radionuclide concentrations are usually Specific Performance Assessment Required wastes at the time of disposal.

The current inventory of these wastes is approximately 955,200 cubic meters. Most of this inventory is uncharacterized wastes (about 90 percent), and the majority is located at the Hanford Site (about 98 percent).

\section{Spent Fuel}

Spent fuel represents irradiated fuel elements that have been permanently discharged from various test, research, and production reactors. The spent-fuel inventory is diverse, consisting of different fuelenrichment levels, fuel matrix types and materials, cladding materials, and burnup rates. Examples range from high uranium-235 enrichment, uranium-zirconium-hydride fuel matrix, stainless steel cladding with graphite plugs, low burnup fuel rods to low uranium-235 enrichment, uranium-oxide fuel particles/carboncoated particles matrix, zirconium cladding, high burn-up fuel rods to depleted uranium, uranium metal fuel matrix, aluminum cladding, low burnup fuel elements. The inventory of spent fuel consists of commercial spent fuel and DOE-managed spent fuel. For a definitive discussion on spent fuel, refer to the Office of Environment, Safety and Health's November 1993 publication, Spent Fuel Working Group Report.

The commercial spent-fuel inventory consists of spent fuel generated from the Non-Defense Test $\&$ Research reactors. These inventories are in storage at the West Valley Demonstration Project in West Valley, New York; the Midwest Fuel Recovery Plant in Morris, Illinois; the Idaho National Engineering Laboratory in Idaho Falls, Idaho; and at various commercial sites. The current inventory amounts to 26,000 metric tons initial heavy metal.

The Department-managed portion of the spent-fuel inventory consists of spent fuel from the shutdown production reactors; various shutdown research reactors and test facilities; reactor irradiated fuel materials requiring special handling (e.g., defective fuel and special fuel forms); and fuels from foreign and university research reactors that are stored at Department of Energy sites. The current inventory amounts to about 2,650 metric tons heavy metal. The majority ( 80 percent) of this material is located at the Hanford Site, of which the $\mathrm{N}$ Reactor fuel assemblies constitute the largest proportion. 


\section{Figure 8. DOE-Managed Spent FueI \\ (Metrlc Tons Heavy Metal)}
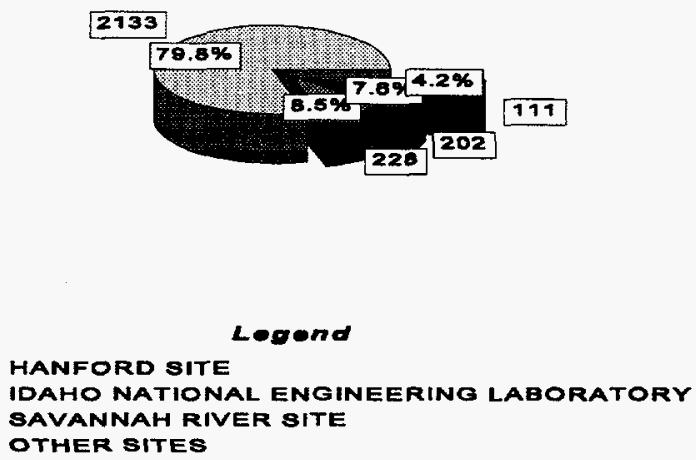

\section{Environmental Restoration Wastes}

Wastes generated during environmental restoration activities are different from those associated with processing operations. These wastes generally contain lower concentrations of radioactive and chemically hazardous substances, and are generally highly heterogeneous in physical form and chemical consistency. The volumes and types of wastes generated depend extensively on the remediation remedy and the treatment technology used.

\section{Site Remediation and Decontamination and Decommissioning}

In general, these wastes are the result of past activities such as radioactive material processing operations, waste disposal practices, spills, and environmental releases. The waste forms can vary from contaminated soil to various facility debris (concrete, wood, metal, brick, etc.) to sediments and sludge. These wastes are classified as either low-level or low-level mixed wastes, or transuranic waste, or $11 \mathrm{e}(2)$ byproduct or $11 \mathrm{e}(2)$ mixed byproduct materials. Byproduct materials are defined in the Atomic Energy Act, section 11e(2) as tailings or waste produced by the extraction or concentration of uranium or thorium from any ore processed primarily for this material. In general, all the transuranic waste is managed as transuranic mixed wastes. Since most remediation efforts are in the assessment phase of the cleanup remedy selection process, only estimates of the expected waste volumes are presented. The projected inventories of contaminated materials, including both Department of Energy onsite and offsite lands and water, which are projected to exist are enormous - in excess of 950 million cubic meters. A breakout of these materials is projected as follows:

- Contaminated ground water -870 million cubic meters

- Contaminated soils -60 million cubic meters

- Other contaminated solid media - 12 million cubic meters

- $\quad$ Contaminated rubble and debris -7 million cubic meters 
Although all these materials do not represent wastes that would be generated, these quantities provide an indication of the magnitude of the environmental contamination that the effort is attempting to address.

A majority of the contaminated ground water is located at the Fernald Environmental Management Project in Ohio, the Hanford Site in Washington, and the Savannah River Site in South Carolina. The radioactively contaminated soil and rubble/debris is primarily low-level or low-level mixed wastes and is expected to primarily come from Los Alamos National Laboratory in New Mexico, the Savannah River Site in South Carolina, the Nevada Test Site in Nevada, and the Hanford Site in Washington.

\section{Uranium Mill Tailings}

Uranium mill tailings are residual wastes from uranium mining, after uranium has been removed, including rock and soil contaminated with small amounts of radioactive materials. This material is primarily $11 \mathrm{e}(2)$ byproduct or $11 \mathrm{e}(2)$ mixed byproduct materials. Total uranium mill tailings associated with the Uranium Mill Tailings Remedial Action Project and vicinity properties are about 34 million cubic meters. In addition, these sites involve about 18 million cubic meters of contaminated ground water. 


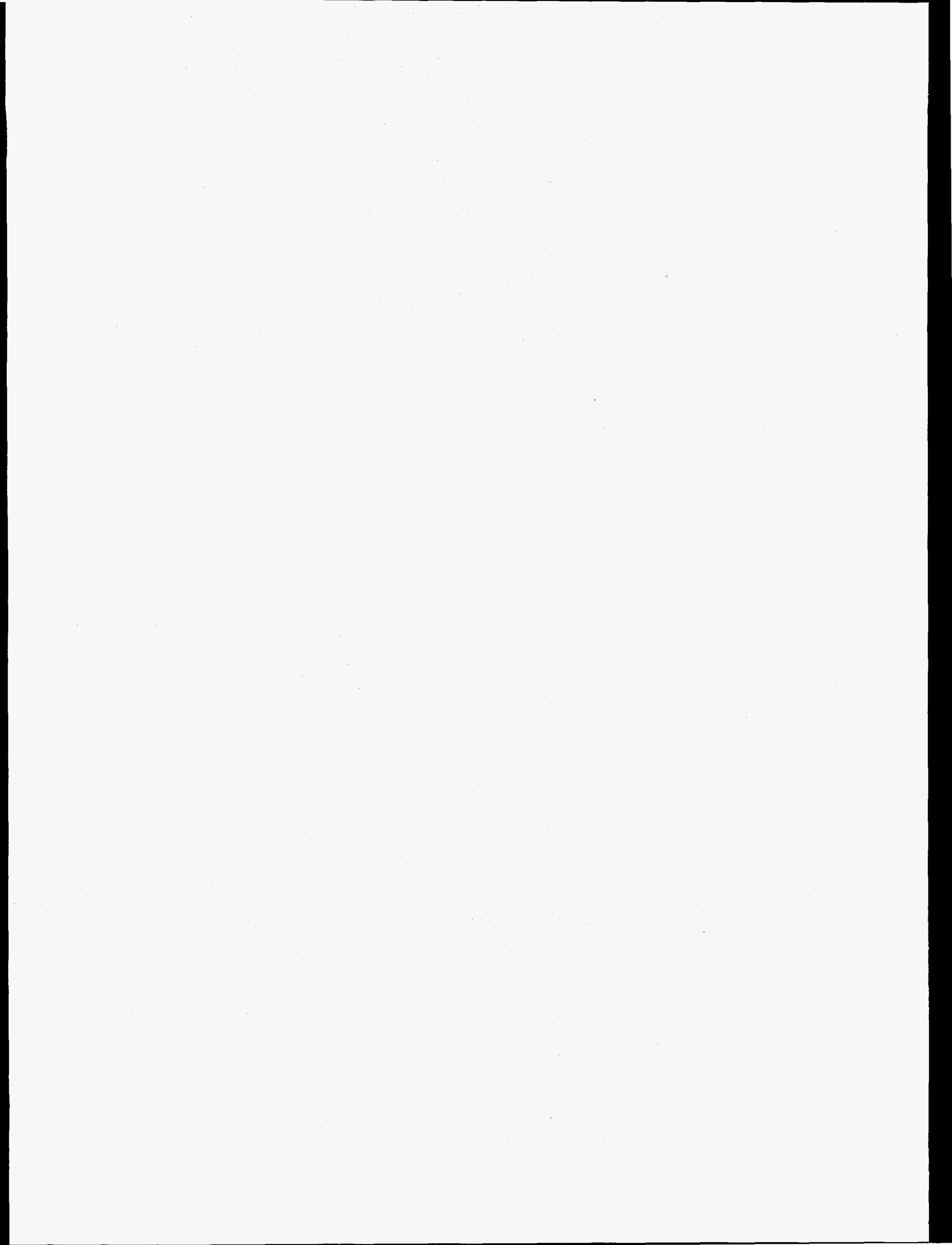




\section{Appendix D}

\section{Current Regulatory Authority for DOE Nuclear Facilities}




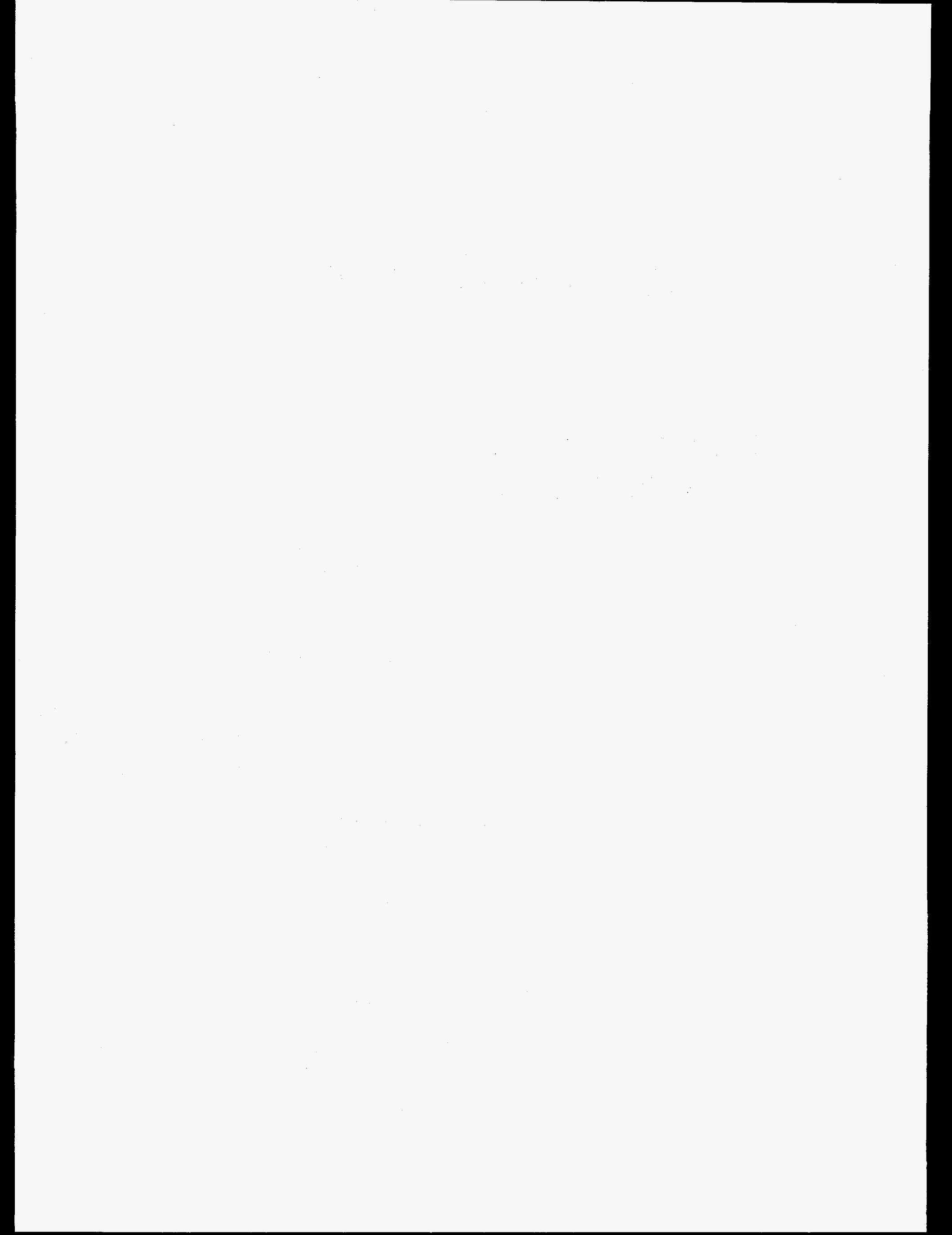




\title{
ADVISORY COMMITTEE ON EXTERNAL REGULATION OF DOE NUCLEAR SAFETY \\ STAFF REPORT
}

\section{REGULATION OF U.S. DEPARTMENT OF ENERGY NUCLEAR FACILITIES: \\ CURRENT REGULATORY JURISDICTIONS AS VIEWED BY REGULATED ACTIVITY}

\author{
Background Report for the \\ Advisory Committee on External Regulation \\ Of DOE Nuclear Safety
}

February 1995 
This Committee staff report is an adaptation of a report prepared under the auspices of the DOE Internal Working Group.

Internal Working Group Report Lead Responsibility: the Office of General Counsel, Deputy General Counsel for Health, Safety \& Environment, Assistant General Counsel for Environment

Internal Working Group Report Contributing Authors: the Office of General Counsel, Deputy General Counsel for Health, Safety \& Environment, Assistant General Counsel for Civilian Nuclear Programs; the Assistant Secretary for Environment, Safety, \& Health, Deputy Assistant Secretary for Nuclear Safety, Office of Nuclear Safety Enforcement. 


\section{CURRENT REGULATORY JURISDICTIONS AS VIEWED BY REGULATED ACTIVITY}

\section{INTRODUCTION}

Internal Working Group Report \#3 examines the current regulatory jurisdictions and statutory authorities of federal and state agencies over DOE nuclear safety. Report No. 3 permits the reader to determine the extent of regulatory authority a given agency has over DOE nuclear facilities. This brief advisory committee staff adaptation of Report No. 3 looks at much the same information from a different vantage point, namely, what aspect of DOE nuclear safety is regulated, and by whom, beginning with facility safety, then worker protection, and finally environmental protection.

In general,

DOE regulates the safety of the design, construction, and operation of its own nuclear facilities. There are some exceptions involving principally the Nuclear Regulatory Commission (NRC). The Defense Nuclear Facilities Safety Board (DNFSB) plays an advisory role with respect to all defense nuclear facilities.

DOE regulates worker safety at most of its own nuclear facilities, but the Occupational Health and Safety Administration (OSHA), or states under delegation from OSHA, regulate worker safety at the rest. DOE and OSHA have entered into a Memorandum of Understanding (MOU) to strengthen occupational safety and health programs at facilities where DOE regulates worker safety.

DOE, the Environmental Protection Agency (EPA), and some states under delegation from EPA regulate to provide protection of the environment. EPA and state regulation takes place under several statutes and covers both radioactive and non-radioactive materials. However, under some environmental protection statutes, DOE's handling of radioactive materials is exempt from EPA regulation.

\section{FACILITY SAFETY}

\section{A. Definition of Facility Safety}

The regulation of facility safety oversees the design, construction, operation, modification, and decommissioning of a facility for the purpose of preventing or mitigating unnecessary or unplanned releases of radioactivity. Such regulation includes the review of personnel training, facility security, emergency planning, and the storage and disposal of radioactive materials. 


\section{B. DOE Self-Regulation of Facility Safety Under the Atomic Energy Act (AEA)}

The AEA largely exempts DOE from external regulation of facility safety. Therefore, DOE self-regulates in this area. This self-regulation is implemented through a system of orders DOE issues under its AEA authority. This system and its implementation, including enforcement mechanisms, are discussed in Internal Working Group Report No. 8, Implementation of DOE Requirements (these do not apply to Naval Reactors).

\section{External Advice}

DOE receives formal advice and recommendations on nuclear facility safety from two external organizations, the Defense Nuclear Facility Safety Board (DNFSB) and the NRC, mainly the former. The DNFSB's role is limited to defense-related nuclear facilities, and the NRC's largely to Naval reactors. No single advisory body covers the full range of DOE nuclear facilities. To date, the DNFSB has issued over 100 formal recommendations, all of which have been accepted by the Secretary. DOE must prepare implementation plans for each of the accepted recommendations. The NRC regularly reviews Naval reactor designs, and other reactor designs upon request by DOE or the Department of Defense. The review is advisory.

\section{Facility-Specific External Regulation of Facility Safety}

At a limited number of DOE facilities, some aspects of facility safety are regulated externally, chiefly by the NRC, but also in some cases by EPA, the Department of Transportation (DOT), and certain other agencies. Below, the facilities are discussed in the order in which they appear in the fuel cycle from mining to disposal.

\section{Uranium Mill Sites}

Remedial actions at these sites are regulated by the NRC pursuant to the Uranium Mill Tailings Radiation Control Act (UMTRCA), or by a state to which the NRC has relinquished regulatory authority pursuant to an agreement between the NRC and the state. The regulation must conform to EPA environmental protection standards.

\section{United States Enrichment Corporation (USEC) Gaseous Diffusion Facilities}

Under the Energy Policy Act of 1992, facility safety at these two facilities will be regulated by the NRC. These facilities are owned by DOE and operated under a lease by USEC, a government corporation established by the same Act of 1992. Generally speaking, these facilities will be subject to the same kind of NRC regulation to which commercial nuclear facilities are subject. However, instead of being licensed by the NRC, these facilities are required, as a condition of operation, to apply annually for an NRC "certification" that the facilities are in compliance with all applicable laws. If the NRC cannot so certify, operation is prohibited unless the NRC approves a USEC plan for achieving compliance. The NRC's review of the application for certification is done in consultation with EPA. The transition to this new regulatory regime is described in more detail in 
Internal Working Group Report No. 9, Transition of the Gaseous Diffusion Plants to External Regulation.

3. Demonstration Reactors and Storage Facilities

Under the Energy Reorganization Act (ERA) of 1974, the NRC regulates facility safety at certain demonstration nuclear reactors and facilities for the storage of high-level radioactive wastes. (The ERA of 1974 abolished the Atomic Energy Commission and divided its functions between the newly-established NRC and DOE's predecessor, the Energy Research and Development Administration.)

4. High-Level Waste Disposal at the Yucca Mountain Site

The NRC will license the construction and operation of the national high-level waste repository pursuant to its authority under the Nuclear Waste Policy Act (NWPA). The NRC's regulation must be consistent with environmental protection standards issued by EPA. The Energy Policy Act of 1992 commissions a study from the National Academy of Sciences (NAS) on how best to set environmental protection standards for the repository, and the EPA standards are required by the Act to be consistent with the Academy's recommendations.

5. Waste Isolation Pilot Project (WIPP)

Several external agencies have a role in regulating, or at least advising the DOE on, facility safety at this pilot project for defense-related waste. EPA's principal role at WIPP under the WIPP Land Withdrawal Act is to certify DOE compliance with EPA's high-level waste disposal standards promulgated pursuant to its radiation standard-setting authority under the AEA and NWPA. The NRC reviews the design and quality of containers for WIPP-destined material. The Mine Safety and Health Administration, the Bureau of Mines, and some other agencies also play a role at WIPP.

\section{Transportation of Radioactive Materials}

DOE self-regulates shipping of nuclear materials for national security purposes. Otherwise, the Department of Transportation sets standards for the packaging and shipping of high-level radioactive waste under the Hazardous Materials Transportation Act, and the NRC certifies containers for highlevel radioactive waste.

\section{WORKER PROTECTION}

\section{A. Definition of Occupational Safety and Health}

Regulation of occupational safety and health oversees the working conditions of employees at nuclear facilities for the purpose of assuring the health and safety of workers. Such regulation requires identification and assessment of hazards (including exposure to toxic substances), and prevention or mitigation of the hazards. 


\section{B. DOE Self-Regulation of Occupational Safety and Health}

DOE largely self-regulates worker health and safety, under a system of internal order and rules (again see Internal Working Group Report No. 8). Self-regulation predominates because the AEA exempts facilities built under the authority of that Act from regulation by the Occupational Safety and Health Administration (OSHA), and most DOE nuclear facilities are built under the authority of that Act. Worker protection at the remaining nuclear facilities, for example WIPP, is regulated by OSHA.

\section{OSHA's Advisory Role}

OSHA also exercises an advisory role with respect to the DOE nuclear facilities it does not regulate. In 1992, DOE and OSHA entered into a memorandum of understanding (MOU) under which OSHA will make available to DOE OSHA expertise and training, and will provide advice on the adequacy of DOE's occupational safety and health program.

\section{ENVIRONMENTAL PROTECTION}

\section{A. Definition of Environmental Protection}

Environmental protection for DOE facilities primarily means controlling the releases of radioactive and nonradioactive wastes to the environment (i.e. air, water, soil) to protect public health and the environment. Environmental protection also involves the treatment, storage, cleanup, and disposal of these wastes.

\section{B. External Regulation of Environmental Protection}

External regulation plays a larger role in environmental protection at DOE than in facility safety or worker protection. Pursuant to several environmental statutes, EPA and "authorized" states, that is, those states to which EPA has delegated authority, regulate non-radioactive substances and, in recent years, have gained increasing regulatory authority over radioactive substances as well. Under these statutes, authorized states may impose environmental standards more stringent than EPA's.

Each of these statutes contains provisions that require federal agencies, including DOE, to comply with the requirements of the statute in the same manner and to same extent as private facilities; and under Executive Order 12088 the head of each Executive agency is responsible for compliance with all applicable pollution control standards. However, radioactive materials are exempted from a few environmental statutes, with the result that DOE is self-regulating in these areas.

This section proceeds statute by statute, summarizing key areas where DOE is and is not subject to external regulation under that statute. The section also summarizes the enforcement tools available to EPA, states, and citizens, and it briefly discusses the protection of "whistleblowers." 
1. Regulation of Non-radioactive Discharges Under the Clean Water Act (CWA):

The purpose of the CWA is to restore and maintain the chemical, physical, and biological integrity of the nation's waters. The CWA prohibits discharges of pollutants from point sources into U.S. surface navigable waters without a permit issued by EPA or an authorized state. This permitting system, called the National Pollution Discharge Elimination System (NPDES), applies to DOE facilities.

As a result of the Supreme Court's decision in Train v. Colorado Public Interest Research Group (426 U.S. 1, 1976), AEA radioactive materials, namely source, special nuclear, and byproduct materials (roughly speaking, fissionable elements in a variety of forms, or byproducts of the processing or use of such elements) cannot be regulated by EPA or the states under the CWA. Therefore, DOE self-regulates releases of these materials.

However, the CWA can apply to non-AEA radioactive materials, namely naturally-occurring and accelerator-produced radioactive materials (NARM). The CWA also specifically prohibits the discharge of any radiological warfare agent or high-level radioactive waste into the nation's waters.

2. Regulation of Radioactive and Non-radioactive Air Emissions Under the Clean Air Act (CAA)

The purpose of the CAA is to protect and enhance the quality of the nation's air resources, in order to promote public health and welfare, and productive capacity. Radionuclides are listed by the Act as hazardous pollutants, and all DOE facilities, including those connected with naval reactors, are covered by the Act. Air emissions of pollutants are regulated by EPA under the CAA through the National Emissions Standards for Hazardous Air Pollutants (NESHAPS). Authorized states impose limits on certain pollutants, called "criteria" pollutants (e.g. lead or sulfur dioxide). As a result of the 1990 amendments to the CAA, each state must develop and implement an operating permit program for all major sources of air pollution within that state. Any DOE facility in that state will have to comply with that state's permit program.

3. Treatment, Storage, and Disposal of Non-radioactive Hazardous Wastes and Radioactive "Mixed" Wastes Under the Resource Conservation and Recovery Act (RCRA)

RCRA regulates the management of hazardous waste from "cradle to grave", covering waste treatment, storage, and disposal facilities, including DOE facilities. The Act requires that such facilities have operating permits from EPA or an authorized state. Like the CWA, RCRA does not cover AEA radioactive materials. Therefore, purely radioactive wastes are regulated by DOE under the AEA. However, much of the radioactive waste at DOE facilities is "mixed" with non-radioactive hazardous waste which is subject to RCRA requirements. RCRA specifically prohibits the storage of untreated mixed wastes. To date, DOE has been unable to comply with this prohibition. The Federal Facilities Compliance Act (FFCA) of 1992 amended RCRA to subject Federal agencies to fines and penalties for violations of RCRA. However, the FFCA delayed the application of this provision to mixed waste storage violations until October, 1995 for DOE and other Federal agencies. The delay of this provision continues provided DOE submits to the regulator (EPA or authorized 
States) and the regulator approves site-specific treatment plans for mixed wastes for each DOE facility handling such waste. Approved plans, however, are legally enforceable.

4. Cleanup of Radioactive and Non-radioactive Wastes Under RCRA and CERCLA

Both RCRA and CERCLA address the cleanup of DOE facilities. RCRA was amended in 1984 to require facilities to include corrective action plans for releases of hazardous wastes and the hazardous part of radioactive mixed wastes in their permits. CERCLA authorizes EPA to require responsible facility owners, operators, generators, and transporters to clean up releases of all hazardous substances, including radioactive substances. In 1986, Congress amended CERCLA to require the most highly contaminated federal facilities listed on the National Priorities List (NPL) to enter into interagency cleanup agreements (IAGs) with EPA. States are parties to these agreements pursuant to their delegated RCRA authority. Currently, most of DOE's major facilities are subject to IAGs with EPA and states.

5. Protection of Groundwater and Drinking Water From Radioactive and Non-Radioactive Contaminants Under the Safe Drinking Water Act (SDWA)

The purpose of the SDWA is to provide safe public drinking water. Pursuant to the SDWA, EPA has promulgated maximum contaminant levels (MCLs) for radioactive and non-radioactive drinking water contaminants for public drinking water systems. The SDWA requires each federal agency, including DOE, having jurisdiction over a drinking water system to comply with EPA or state requirements. The MCLs also impact DOE cleanups under CERCLA, because they are often used as cleanup standards (commonly referred to as "applicable or relevant and appropriate requirements" (ARARs)). DOE is also subject to EPA and state programs for preventing contamination of underground sources of drinking water by underground injection of contaminated fluids.

6. Manufacture, Use, and Distribution of Non-Radioactive Chemical Substances under the Toxic Substances Control Act (TSCA)

TSCA was enacted to provide a safeguard against the introduction of new contaminants into the environment, and to address risks posed by existing chemicals. The Act enables EPA (TSCA does not have a authorized state program) to collect information about chemical hazards, and to take action to control unreasonable risks either by preventing new chemicals from coming into use, or by restricting those already in use. TSCA fills a gap left by the other environmental laws, for while they control only disposal or release to the environment, TSCA enables EPA to control the entire life cycle of a toxic substance, from production, through distribution in commerce, to disposal.

The primary way TSCA affects DOE facilities is through its regulation of PCBs, although the Act also restricts the availability of certain materials for DOE purchase. TSCA does not apply to AEA radioactive materials, but, like RCRA, it applies to the $P C B$ portion of waste mixed with radioactive materials. 


\section{Compliance with the National Environmental Policy Act (NEPA)}

DOE must also comply with NEPA, which requires, among other things, that every Federal agency prepare a document analyzing the environmental impact of any "major action" the agency undertakes which significantly affects the quality of the human environment. These "environmental impact statements" (EIS) can be challenged in Federal court.

\section{EPA, State, and Citizen Enforcement of Environmental Protection}

Although EPA may not sue another Executive Agency, including DOE, in federal court for environmental violations, EPA does have administrative enforcement authority to require information gathering, performance reporting, and recordkeeping. EPA also has some authority to impose administrative orders and penalties on DOE, most notably under CERCLA and RCRA.

In many instances, states regulate DOE, generally pursuant to an authorization from EPA. A necessary condition of state regulation of DOE is a waiver of sovereign immunity, under which the Congress directs a Federal agency to comply with a Federal, state, or local requirement. Most Federal environmental laws contain waivers of sovereign immunity. The regulatory role of states encompasses everything from standard setting to assessment of civil fines and penalties (if sovereign immunity is specifically waived for fines and penalties). Moreover, EPA-authorized states, unlike EPA, can generally sue DOE for non-compliance. In general, Federal environmental statutes allow states to impose more stringent standards.

Nearly every major environmental statute has a citizen suit provision. Such a provision allows a citizen to sue a government agency, including DOE, in order to enforce compliance with the pertinent environmental statute. Generally, a citizen suit is precluded where EPA or a state (where relevant) is diligently prosecuting an enforcement action. The AEA and NWPA do not have citizen suit provisions, but they do have sections providing for judicial review of agency action, and the AEA requires that the NRC offer opportunities for hearings on such actions as the issuance or amendment of licenses. Generally, a person may also bring a suit to challenge a final agency action under the Administrative Procedure Act.

Workers at regulated facilities also play an important role in assuring compliance with applicable laws and in spotting emerging threats to facility safety, worker protection, and environmental protection. Several statutes, including the Energy Reorganization Act of 1974 (as amended by the Energy Policy Act of 1992), the Occupational Safety and Health Act (OSHA), and most environmental statutes, protect workers at DOE facilities from reprisal for reporting violations, or possible violations, of safety regulations.

\section{DOE Internal Regulation of Environmental Protection}

Where DOE is exempt from the requirements of CWA, RCRA and TSCA, it regulates through its own system of orders, issued under its AEA authority. Thus it self-regulates releases of AEA materials to surface navigable waters; on-site treatment, storage, and disposal of purely radioactive wastes and the radioactive portion of mixed wastes; and the manufacture, use, and distribution of radioactive materials. DOE's implementation of its system of orders is described in Internal Working Group Report No. 8. Since the AEA does not provide for citizen suits, citizens may not sue to enforce DOE's internal orders. 
DOE also assists external regulators with implementation of their requirements. Some of this implementation takes place through the system of orders, and some of it takes place on a daily basis through DOE Operations Offices and certain Headquarters Offices, including Environment, Safety, and Health. DOE Implementation of external requirements includes provision for fines and other penalties against either DOE, a contractor, or both. 


\section{Appendix E}

National Security and External Regulation of Nuclear Safety 

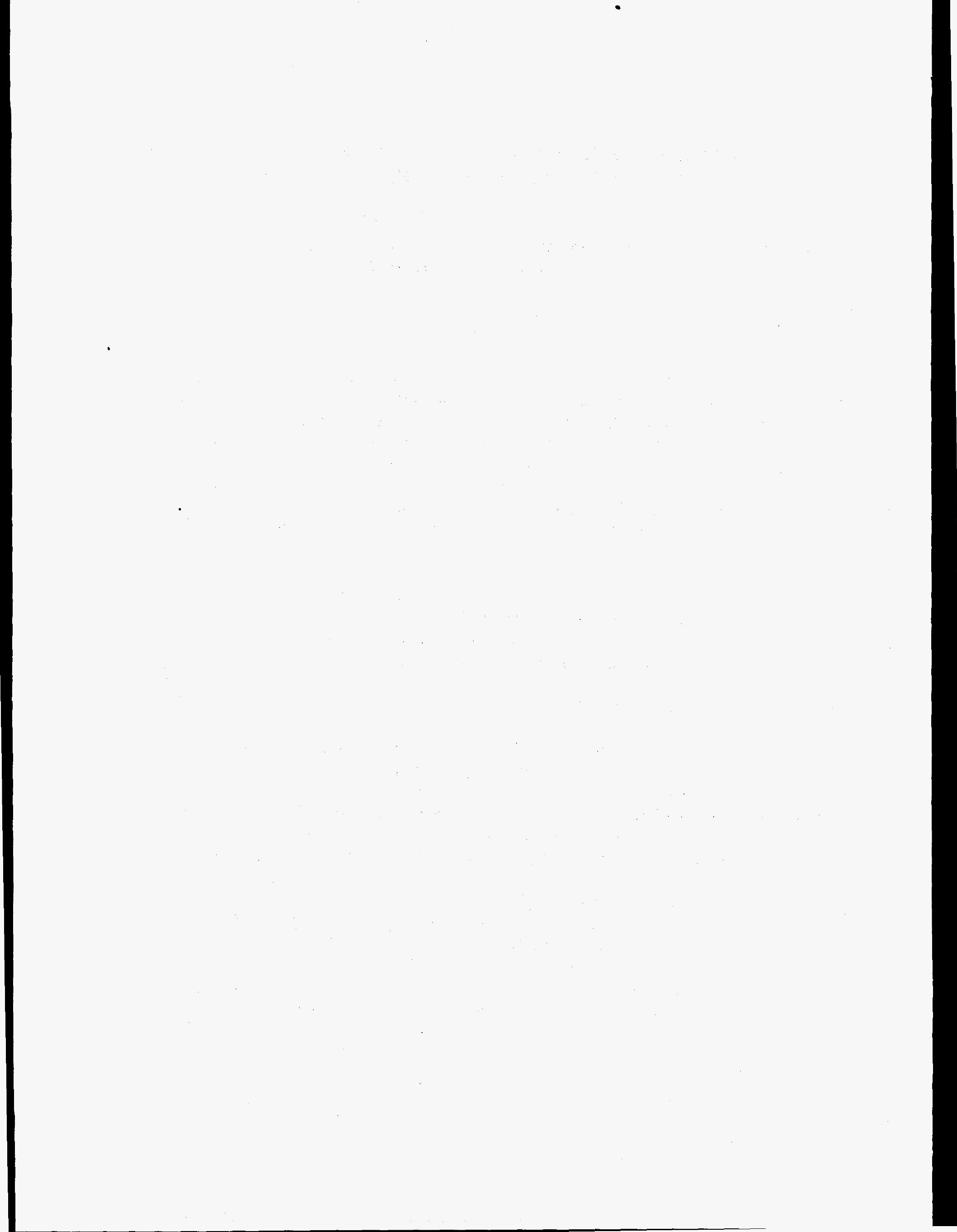


\title{
ADVISORY COMMITTEE ON EXTERNAL REGULATION OF DOE NUCLEAR SAFETY
}

\author{
Subcommittee on Task 6 - External Regulation of Nuclear Safety and National Security \\ (Final Draft - September 27, 1995)
}

\section{INTRODUCTION}

For more than four decades, the primary mission of the nuclear weapons complex was to produce special nuclear materials (SNM) ${ }^{1}$ and nuclear weapons. With the end of the Cold War, the emphasis has properly shifted from weapons and materials production to weapons stewardship and dismantlement, waste management, and cleanup. The Department of Energy (DOE) is in the process of consolidating and streamlining the complex in order to more efficiently manage the enduring weapons stockpile. An important national security mission remains, balanced now by a major, long-term environmental management and restoration process. Regardless of the particular mission or national security interest involved, there remains a need for DOE's activities to be conducted in a manner that protects public health, worker safety, and the environment.

Any future external regulation of Department of Energy (DOE) must therefore balance nuclear safety and other concerns with national security interests. The following discussion divides this concept into four issues: (1) regulatory oversight and national security, (2) regulation of nuclear explosive operations, (3) protection of classified information, and (4) regulation of safeguards and facility security.

\section{Regulatory Oversight and National Security}

The Department's ongoing national security activities have important implications for health, safety, and the environment. In light of these implications, DOE's defense activities should, as a general matter, be fully subject to the external regulatory scheme our committee intends to propose. Any exceptions must be carefully justified, defined, and limited. At the same time, however, the external regulatory scheme must not unduly impede legitimate national security interests. After assessing the relevant issues, our subcommittee believes it is entirely possible to protect safety and national security at the same time.

The regulatory scheme should be flexible enough to deal with the real safety consequences of issues that arise in the national security arena. If a DOE facility has a problem complying with a safety regulation, the DOE facility involved would be expected to work constructively and cooperatively with the regulator to agree on a technical path forward. The process should include issue resolution mechanisms (for example, negotiated compliance agreements or consent orders) between DOE and the regulator that are timely and that minimizes the necessity for appealing to authorities outside DOE and the regulating agency. plutonium.

1 Special nuclear material includes uranium enriched in its fissionable isotopes (U-233 and U-235) and 
If it is not possible to resolve between DOE and the regulator an issue concerning compliance with an applicable requirement or standard, the process should provide for the President to make a final decision on a case-by-case basis that balances national security and safety. A precedent for this approach exists under environmental statutes, including the Clean Air Act, Safe Drinking Water Act, Resource Conservation and Recovery Act, and Comprehensive Environmental Response Compensation and Liability Act. These statutes contain provisions that require each department or agency of the Federal Government to comply with the requirements to the same manner and extent as nongovernmental entities. These statutes also contain provisions that allow the President to exempt a federal facility from compliance with a regulatory requirement, if the President determines it to be in the "interest of national security" or "paramount interest of the United States." Under the National Environmental Policy Act (NEPA), regulations of the Council on Environmental Quality (CEQ) allow a federal agency, in consultation with CEQ, to take an action with significant environmental impacts without observing NEPA requirements under "emergency circumstances."

Executive Order 12088 provides the mechanism for the Presidential exemption under the environmental statutes. The order allows the head of an agency to recommend to the President, through the Director of the Office of Management and Budget (OMB), that an activity or facility be exempt from a pollution control standard. The Administrator of EPA advises the President, through OMB, whether the Administrator agrees with the exemption and $\mathrm{OMB}$ is then required to make a final recommendation to the President within 60 days. An executive order could also be used to delegate the exemption authority to some other senior government official if necessary to expedite the process. Preferably, the official would be a political appointee or some other individual in the position to equitably balance the environment, health and safety and national security interests involved.

\section{Regulation of Nuclear Explosive Operations}

Nuclear explosive operations include a range of DOE activities including assembly, transportation, maintenance, storage, testing, and disassembly of a nuclear explosive or weapon. As such, these operations often involve circumstances in which high explosives (HE) are deliberately in proximity to SNM. Because these operations involve the ongoing support of the nation's weapon stockpile and the use of highly sensitive nuclear weapon and use control design information, they are among the most important national security functions undertaken by DOE.

For purposes of this report, we define nuclear explosive safety as the formalized program designed to prevent the accidental or unauthorized detonation of HE while in the proximity of SNM during nuclear explosive operations. Nuclear explosive safety is unique to DOE and is currently implemented in DOE series 5610 safety orders.

The subcommittee recommends that the regulation of nuclear explosive safety remain a DOE responsibility outside the scope of external regulation. In other words, the regulator would not be able to regulate or assess the safety of the nuclear explosive device itself (i.e., whether the device will detonate) during nuclear explosive operations. The subcommittee makes this recommendation to avoid drawing the regulator into the unique national security interests and specialized knowledge involved with nuclear explosive safety, in particular the classified design and configuration of a nuclear weapon or explosive device. It also assures that weapon specific issues are dealt within a timely manner utilizing the most relevant technical resources. 
However, it is important that this exclusion be carefully and narrowly implemented so that other safety aspects of the facility, wherein nuclear explosive operations are conducted, are not excluded from the scope of external regulation. The subcommittee recommends that nuclear explosive operations other than nuclear explosive safety be subject to external regulation. Therefore, the regulator would establish standards for nuclear explosive operations in consultation with DOE. The standards would be performance-based and would allow DOE flexibility and discretion in operating procedures to demonstrate that operations conform to standards.

To verify compliance with standards, the regulator would be provided DOE safety analysis documentation and other information including bounding data on SNM and toxic and hazardous materials. DOE manuals, guides, and operating procedures would also be made available to demonstrate compliance with safety standards. The regulator would be able to certify compliance with standards by inspecting a facility and could access a bay or cell, including those where weapon operations are underway, by means such as close circuit TV. However, the regulatory system should also take into account the sensitive nature of the operations. Therefore, the regulator would always be escorted by a knowledgeable federal employee or $\mathrm{M} \& \mathrm{O}$ contractor employee from the site being regulated and could not have hands-on access to a nuclear explosive device. Similarly, the regulator would not have access to specific nuclear weapon or control design information.

There is precedent for this kind of exemption under the Hazardous Materials Transportation ACT (HMTA). The Department of Transportation (DOT) regulations under HMTA restrict the commingling of HE and other hazardous (including radioactive) material in transit. However, shipments of radioactive material and $\mathrm{HE}$ under the direction or supervision of DOE, and which are escorted by personnel designated by or under the authority of DOE, for the purpose of national security are not subject to DOT regulations in this area.

\section{Protection of Classified Information}

An external regulator will need to have access to classified information and operations to ensure compliance with safety standards and regulations. However, it is important that the classified information be protected. The proper way to address this issue is to subject the regulators to the DOE security regime including the clearance process. Currently, EPA, State, and Defense Nuclear Facility Safety Board officials must obtain a "Q" clearance or equivalent and have a "need to know" before obtaining classified information or gaining access to classified facilities or operations. The process of clearing regulators has worked well in the past, and the subcommittee believes that classification issues do not pose a problem for a system of external regulation.

The subcommittee has recommended that the scope of external regulation not include nuclear explosive safety. Therefore, access to nuclear explosive design data should be limited. The regulator may receive this selected information on a "need to know" basis as necessary to observe nuclear explosive operations or to evaluate impacts on nuclear safety. In order to observe these processes, regulators would also be required to be in a human reliability program, such as the Personnel Security Assurance Program or equivalent. This is needed because the regulator would be close to nuclear explosives. The regulator would also need to be trained in and become acquainted with nuclear explosives and operations, facilities used for nuclear explosives operations and associated activities, and overall policies and practices at the site being regulated. The procedures used by DOE to clear and train individuals are described below. 


\section{Regulation of Material Safeguards and Facility Security}

The DOE employs an integrated system of security programs at its facilities to protect SNM, classified information, and property. The system calls for a graded approach based on classified threat guidance, the attractiveness of the material, and the information being protected. Except for the specialized areas of nuclear weapons and the Transportation Safeguards System, the security afforded DOE facilities is similar to that required for NRC-licensed material processing plants or Department of Defense sensitive military installations.

The DOE security program rests on three interlocking elements: (1) material control and accountability, (2) physical security, and (3) personnel security. The system of materials control and accountability identifies, measures, and tracks the movement of SNM within the DOE complex and its facilities. The purpose of the system is to avoid or detect the loss or diversion of accountable quantities of SNM. The features of the system such as accounting methods, measurement equipment, tamper-indicating devices, and bar-coded labels are very similar to those used by NRC licensees. Physical security is often described as "guns, gates, and guards," but also includes features such as alarms, safes, document control, and information classification. The specific performance requirements of the physical security systems at a facility are documented in a Site Safeguards and Security Plan (SSSP) which is approved at the headquarters level for the most sensitive facilities. The SSSP serves as the basis for performance-based review and testing by the oversight group from the Office of Environment Safety and Health at headquarters.

Personnel security is a tiered approach to ensure that personnel with access to classified information or SNM are trustworthy and reliable. The basic element of the system is the security clearance background check and periodic reinvestigation combined with a "need to know." The criteria for eligibility to possess a DOE clearance are enumerated in DOE regulations at 10 C.F.R. Part 710. If based on the specified criteria, DOE determines that an applicant should not receive clearance, DOE notifies the individual of the right to an administrative hearing before a Hearing Officer. Although the formal rules of evidence do not apply, the individual can be represented by counsel, present evidence, cross-examine witnesses where possible, etc. The applicant may appeal the recommendation of the Hearing Officer to the Director, Office of Hearings and Appeals (OHA). The opinion of the Director of the OHA is then transmitted to the Director, Office of Security Affairs (OSA) who makes the final determination. Where an individual is not afforded the opportunity of cross-examination, the Secretary of Energy must make the final determination.

Additional human reliability programs for persons in sensitive positions in DOE include: (1) Personnel Security Assurance Program (PSAP) for those requiring hands-on access to strategic quantities of SNM or holding critical positions that could affect national security, and (2) Personnel Assurance Program (PAP), a nuclear explosive safety program, for those with hands-on access to nuclear weapons. The common elements of PSAP and PAP include frequent evaluation of participants by medical and psychological exams, observation of behavior by co-workers and supervisors, routine drug testing, and annual recertification of continued eligibility. The most sensitive aspect of DOE security information is the identification and analysis in the SSSP of vulnerabilities that may exist in the integrated security scheme for a given facility. Even within DOE, this type of information is held close with access granted only on a strict "need-to-know" basis. Similarly, information on individuals in the personnel security programs is closely protected under the Privacy Act. Nearly all security information at specific DOE facilities is classified. 
The subcommittee considered whether the safeguards and security program should fall under an external regulatory regime. Although there are models for external regulation in this area, most notably by the Nuclear Regulatory Commission, the subcommittee has proposed that safeguards and security initially remain a DOE function to avoid diluting a regulator's focus on nuclear safety. However, an external regulator would require information and the opportunity to observe DOE regulation of material safeguards and facility security as necessary to understand and evaluate any impacts on nuclear safety. 


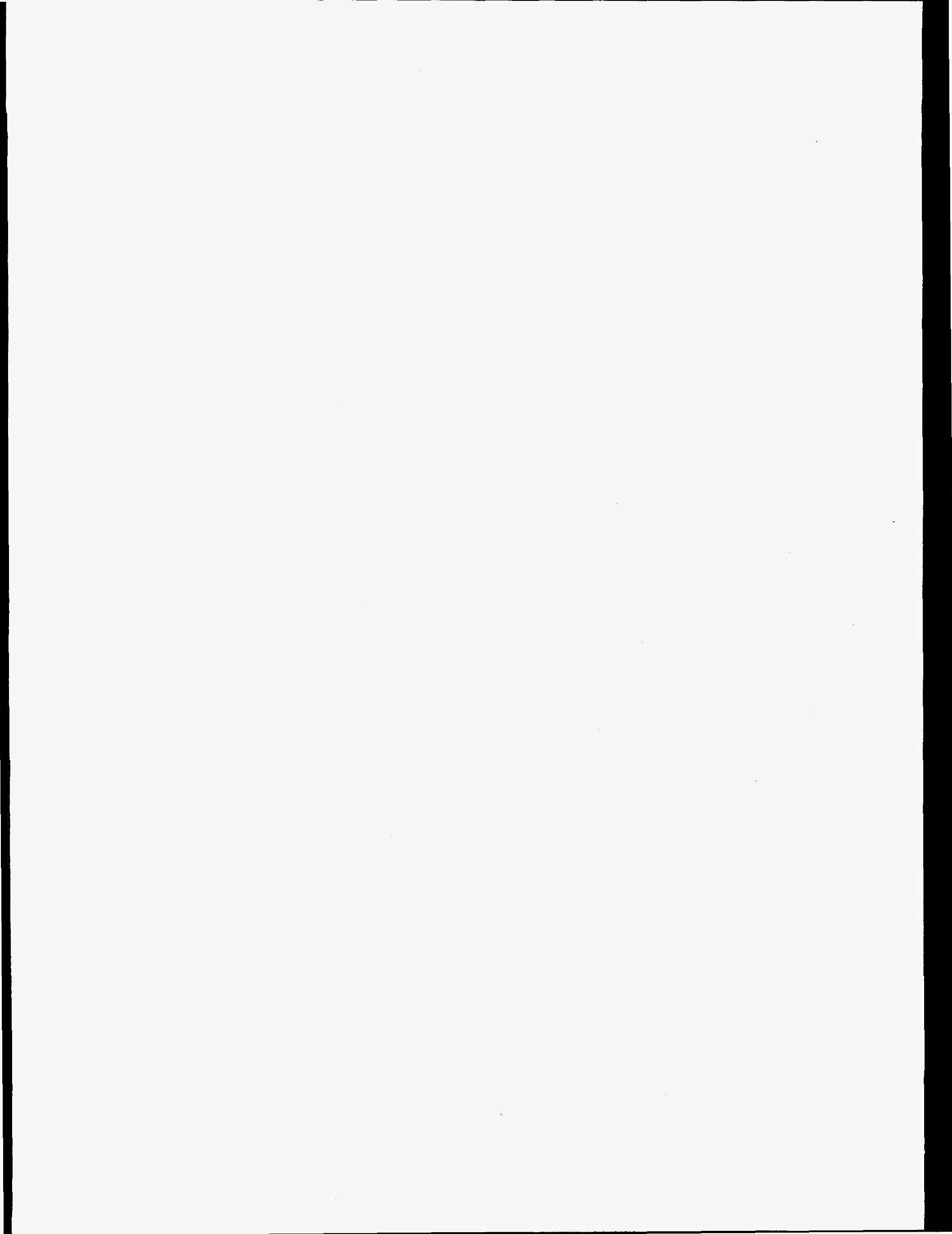


F I N A L R E P O R T

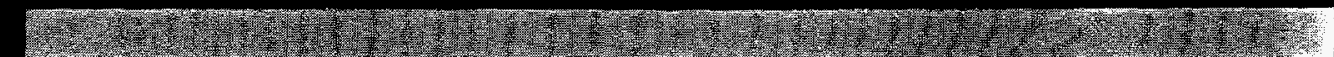

Improving

Regulation of

Safety at

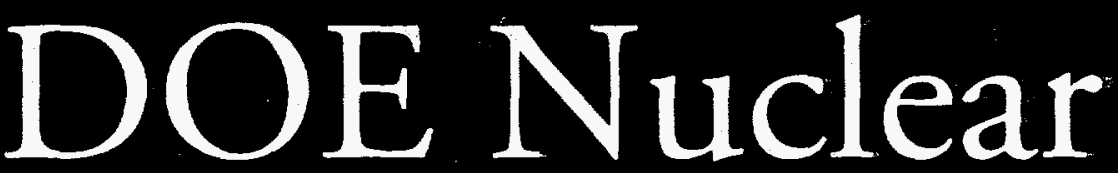

Facilities

December 1995

Appendices

Advisory Committee on External Regulation of

Department of Energy Nuclear Safety 


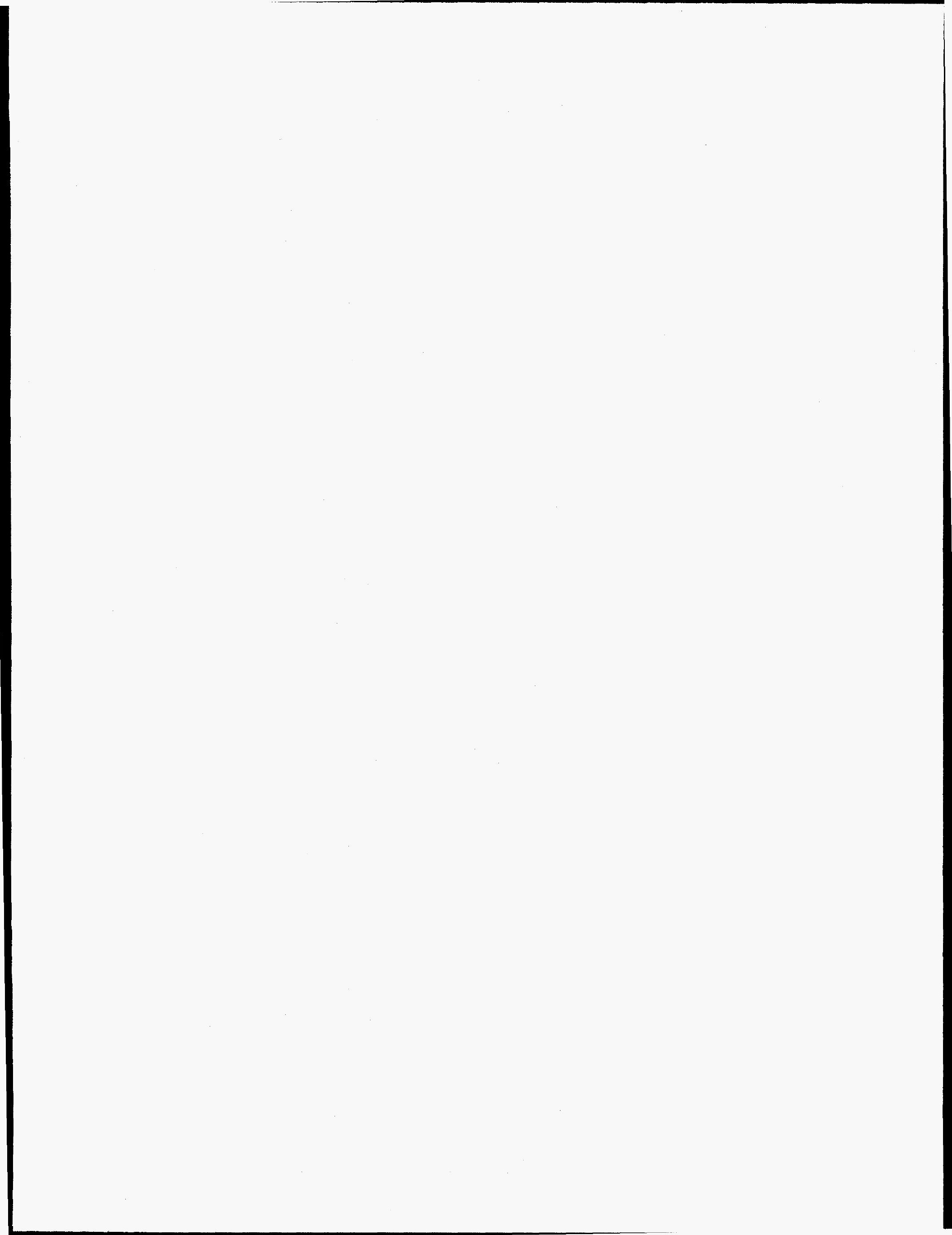

